
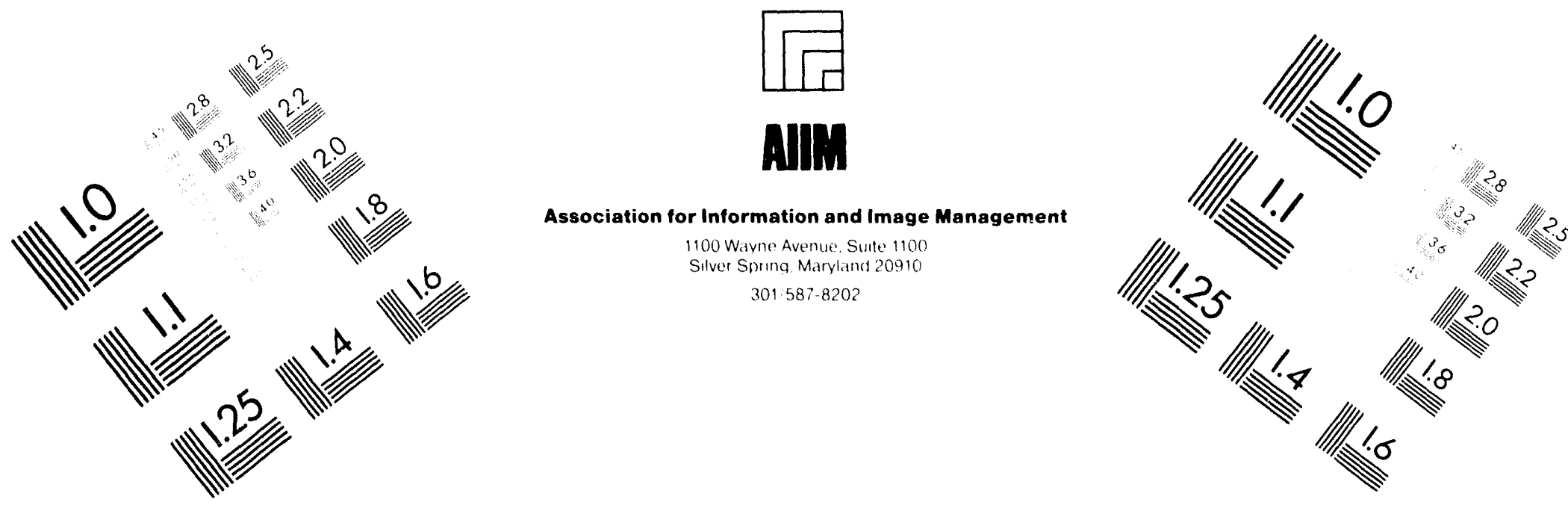

Centimeter

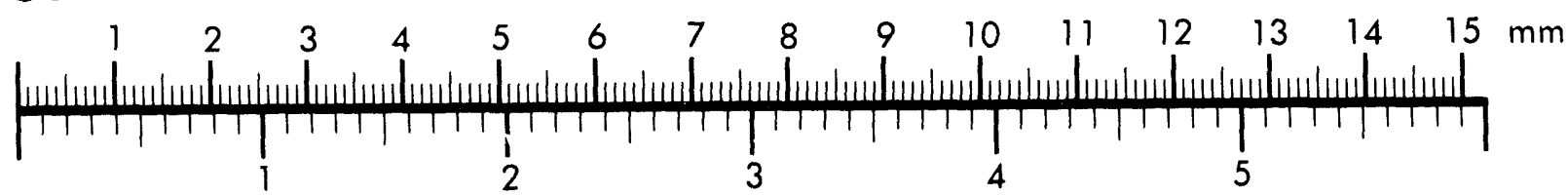

Inches
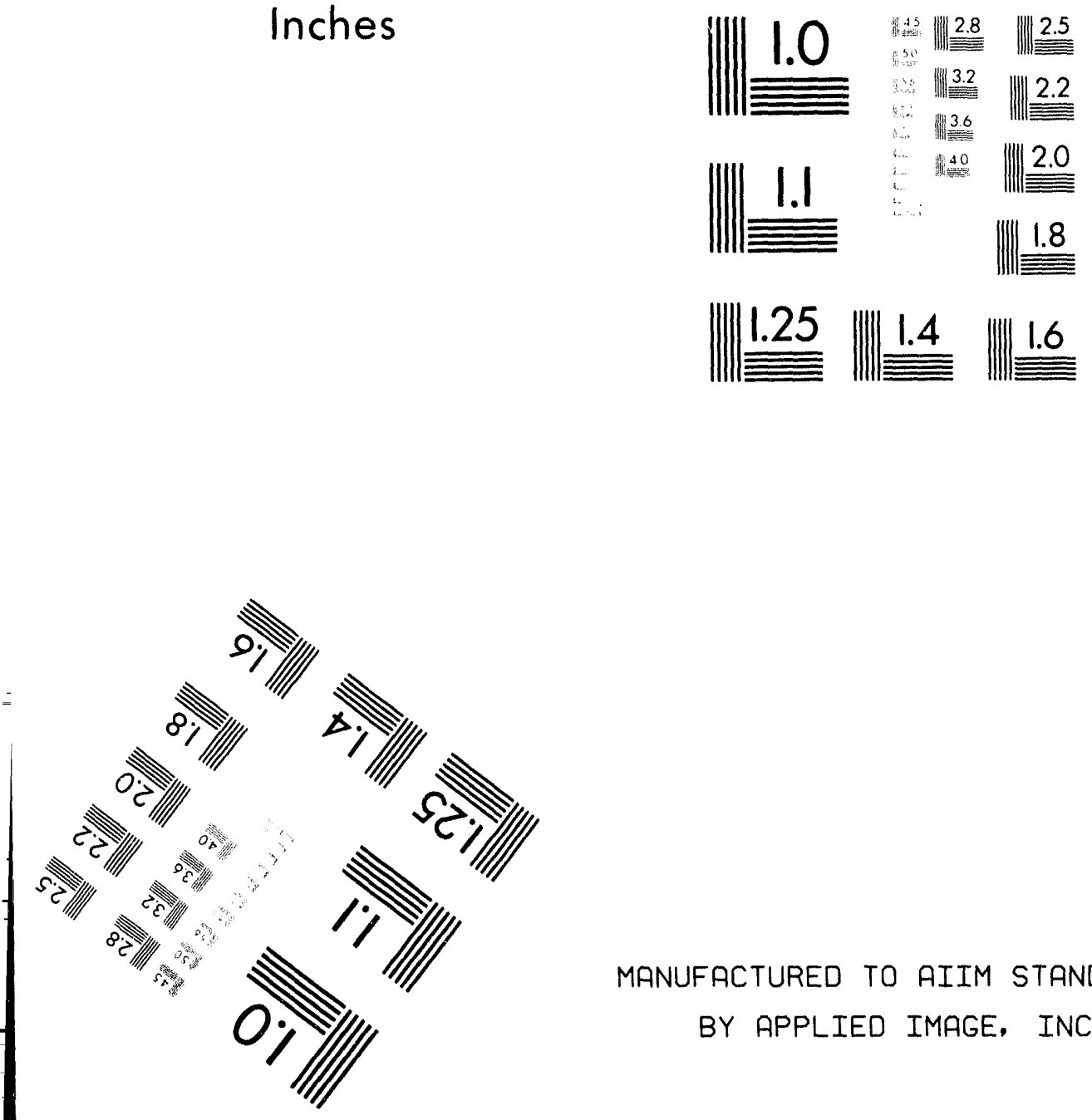

MANUFACTURED TO AIIM STANDARDS

BY APPLIED IMAGE, INC.

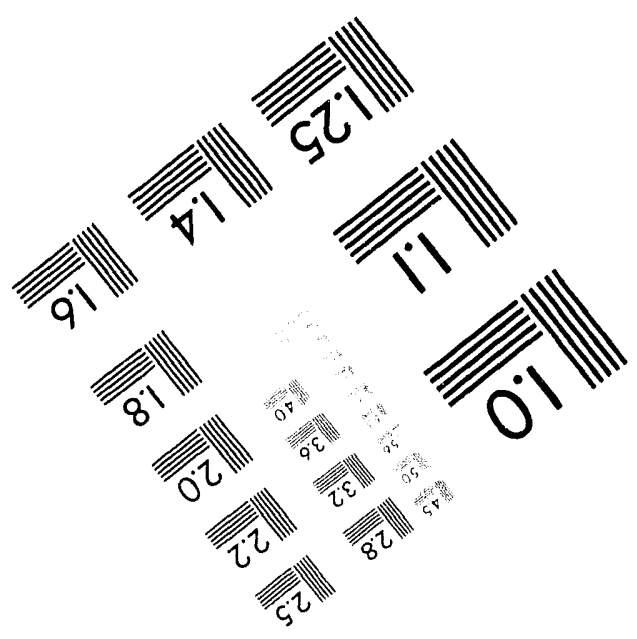



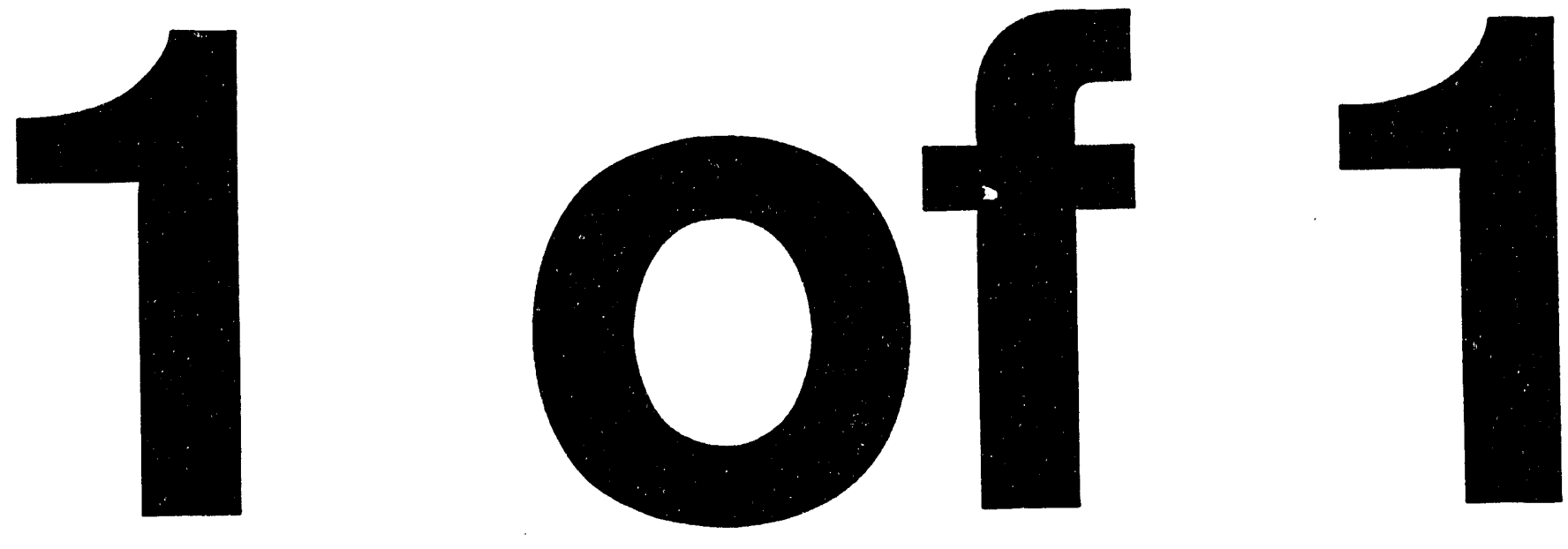
NUREG/CR-4667

ANL-94/16

Vol. 17

\section{Environmentally Assisted Cracking in Light Water Reactors}

Semiannual Report

April 1993-September 1993

Manuscript Completed: April 1994

Date Published: June 1994

Prepared by

O. K. Chopra, H. M. Chung, T. Karlson, T. F. Kassner, W. F. Michaud,

W. E. Ruther, J. E. Sanecki, W. J. Shack, W. K. Soppet

Argonne National Laboratory

9700 South Cass Avenue

Argonne, IL 60439

\section{Prepared for}

Division of Engineering

Office of Nuclear Regulatory Research

U.S. Nuclear Regulatory Commission

Washington, DC 20555-0001

NRC FIN A2212

\section{DISCLAIMER}

This report was prepared as an account of work sponsored by an agency of the United States pererent nor any agency thereof, nor any of their Government. Neither the United States Government nor any agency legal liability or responsiemployees, makes any warranty, express or implied, or assumes any lion, apparatus, product, or bility for the accuracy, completeness, or usefulness of any information, apparatus, product process disclosed, or represents that its use would not infringe privately owned trade name, trademark, ence herein to any specific commercial product, process, or service by trade nase, its endorsement, recommanufacturer, or otherwise does not necessarily constitute or imply its endorsem. The views mendation, or favoring by the United States Government or any agency the reflect those of the and opinions of authors expressed herein do not 


\section{Previous Documents in Series}

Environmentally Assisted Cracking in Light Water Reactors Semiannual Report AprilSeptember 1985. NUREG/CR-4667 Vol. 1, ANL-86-31 (June 1986).

Environmentally Assisted Cracking in Light Water Reactors Semiannual Report October 1985March 1986, NUREG/CR-4667 Vol. II, ANL-86-37 (September 1987).

Environmentally Assisted Cracking in Light Water Reactors Semiannual Report AprilSeptember 1986, NUREG/CR-4667 Vol. III, ANL-87-37 (September 1987).

Environmentally Assisted Cracking in Light Water Reactors Semiannual Report October 1986March 1987, NUREG/CR-4667 Vol. IV, ANL-87-4l (December 1987).

Environmentally Assisted Cracking in Light Water Reactors Semiannual Report AprilSeptember 1987. NUREG/CR-4667 Vol. V. ANL-88-32 (June 1988).

Environmentally Assisted Cracking in Light Water Reactors Semiannual Report October 1987March 1988, NUREG/CR-4667 Vol. 6, ANL-89/10 (August 1989).

Environmentally Assisted Cracking in Light Water Reactors Semiannual Report AprilSeptember 1988. NUREG/CR-4667 Vol. 7, ANL-89/40 (March 1990).

Environmentally Assisted Cracking in Light Water Reactors Semiannual Report October 1988March 1989, NUREG/CR-4667 Vol. 8, ANL-90/4 (June 1990).

Environmentally Assisted Cracking in Light Water Reactors Semiannual Report AprilSeptember 1989, NUREG/CR-4667 Vol. 9, ANL-90/48 (March 1991).

Environmentally Assisted Cracking in Light Water Reactors Semiannual Report October 1989March 1990, NUREG/CR-4667 Vol. 10, ANL-91/5 (March 1991).

Environmentally Assisted Cracking in Light Water Reactors Semiannual Report AprilSeptember 1990, NUREG/CR-4667 Vol. 11, ANL-91/9 (May 1991).

Environmentally Assisted Cracking in Light Water Reactors Semiannual Report October 1990March 1991, NUREG/CR-4667 Vol. 12, ANL-91/24 (August 1991).

Environmentally Assisted Cracking in Light Water Reactors Semiannual Report AprilSeptember 1991, NUREG/CR-4667 Vol. 13, ANL-92/6 (March 1992).

Environmentally Assisted Cracking in Light Water Reactors Semiannual Report October 1991March 1992, NUREG/CR-4667 Vol. 14. ANL-92/30 (August 1992).

Environmentally Assisted Cracking in Light Water Reactors Semiannual Report AprilSeptember 1992. NUREG/CR-4667 Vol. 15, ANL-93/2 (June 1993).

Environmentally Assisted Cracking in Light Water Reactors Semiannual Report October 1992March 1993. NUREG/CR-4667 Vol. 16, ANL-93/27 (September 1993). 


\title{
Environmentally Assisted Cracking in Light Water Reactors
}

by

O. K. Chopra, H. M. Chung, T. Karlsen, T. F. Kassner, W. F. Michaud,

W. E. Ruther, J. E. Sanecki, W. J. Shack, and W. L. Soppet

\begin{abstract}
This report summarizes work performed by Argonne National Laboratory on fatigue and environmentally assisted cracking (EAC) in light water reactors (LWRs) during the six months from April 1993 to September 1993. EAC and fatigue of piping, pressure vessels. and core components in LWRs are important concerns as extended reactor lifetimes are envisaged. Topics that have been investigated include (a) fatigue of low-alloy steel used in piping, steam generators, and reactor pressure vessels, (b) EAC of cast stainless steels (SSs), and (c) radiation-induced segregation and irradiation-assisted stress corrosion cracking of Type 304 SS after accumulation of relatively high fluence. Fatigue tests were conducted on medium-sulfur-content A106-Gr B piping and A533-Gr B pressure vessel steels in simulated PWR water and in air. Additional crack growth data were obtained on fracture-mechanics specimens of cast austenitic SSs in the as-received and thermally aged conditions in simulated boiling-water reactor (BWR) water at $289^{\circ} \mathrm{C}$. The data were compared with predictions based on crack growth correlations for wrought austenitic SS in oxygenated water developed at ANL and rates in air frum Section XI of the ASME Code. Microchemical and microstructural changes in high- and commercial-purity Type 304 SS specimens from control-blade absorber tubes and a control-blade sheath from operating BWRs were studied by Auger electron spectroscopy and scanning electron microscopy.
\end{abstract}




\section{Contents}

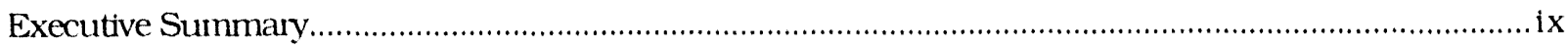

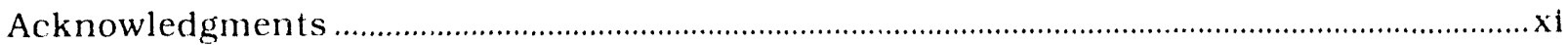

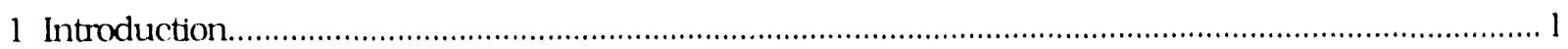

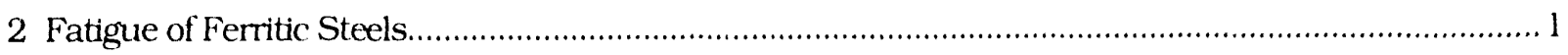

2.1 Technical Progress (O. K. Chopra, W. F. Michaud, W. J. Shack,

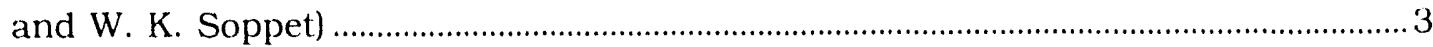

3 Environmentally Assisted Cracking of Cast SSs in Simulated BWR Water....................... 22

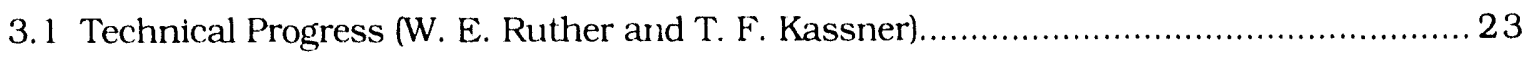

4 Irradiation-Assisted Stress Corrosion Cracking of Austenitic SS................................. 35

4.1 Role of Trace Elements in SCC of Irradiated Austenitic SSs

(H. M. Chung, W. E. Ruther, and J. E. Sanecki) ………................................................. 35

4.2 Effect of Water Chemistry on IASCC Susceptibility

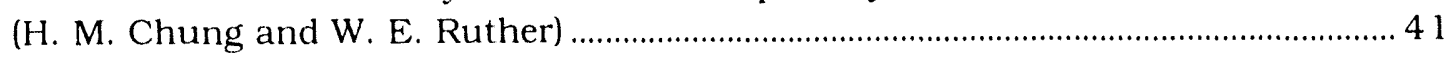

4.3 Irradiation of Austenitic SS Alloys in Halden Reactor

(T. Karlsen and H. M. Chung)...

4.4 J-R Fracture Toughness Test of Irradiated Austenitic SS

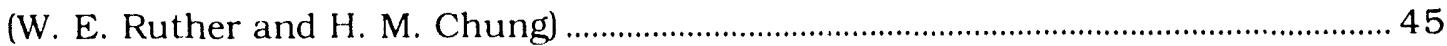

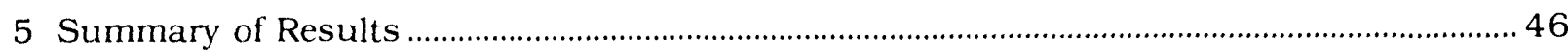

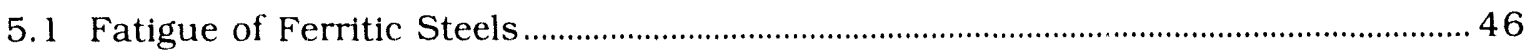

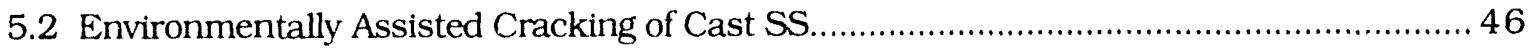

5.3 Irradiation-Assisted Stress Corrosion Cracking of Type 304 SS .............................. 47

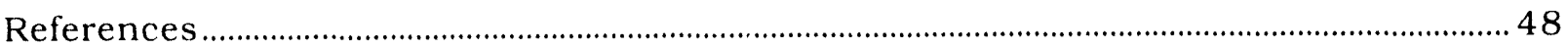




\section{Figures}

1. Total strain range vs. fatigue life data for A 106-Gr B steel in air....................................... 8

2. Total strain range vs. fatigue life data for A533-Gr B steel in air..................................... 8

3. Micrographs of typical fatigue cracks along longitudinal sections of A 106Gr B carbon steel and A533-Gr B low-alloy steel specimens.

4. Total strain range vs. fatigue life data for A 106-Gr B steel in PWR water at $288^{\circ} \mathrm{C}$

5. Total strain range vs. fatigue life data for A533-Gr B steel in PWR water at $288^{\circ} \mathrm{C}$

6. Total strain range vs. fatigue life data for A106-Gr B steel in high-oxygen water at $288^{\circ} \mathrm{C}$.......

7. Total strain range vs. fatigue life data for A533-Gr B steel in high-oxygen water at $288^{\circ} \mathrm{C}$.......

8. Relative fatigue life of A106-Gr B carbon steel at different levels of DO and strain rates.

9. Relative fatigue life of A533-Gr B low-alloy steel at different levels of DO and strain rates

10. Morphology and micrographs of fatigue cracks before and after descaling of gage surface of A 106-Gr B specimen tested in air.

11. Morphology and micrographs of fatigue cracks before and after descaling of gage surface of A106-Gr B specimen tested in simulated PWR water.

12. Morphology and micrographs of fatigue cracks before and after descaling of gage surface of Al06-Gr B specimen tested in water containing $\approx 0.8 \mathrm{ppm}$ DO.

13. Morphology and micrographs of fatigue cracks before and after descaling of gage surface of A533-Gr B specimen tested in air

14. Morphology and micrographs of fatigue cracks before and after descaling of gage surface of A533-Gr B specimen tested in simulated PWR water

15. Morphology and micrographs of fatigue cracks before and after descaling of gage surface of A533-Gr B specimen tested in water containing 0.8 ppm DO .

16. Micropits on surface of A106-Gr B carbon steel and A533-Gr B low-alloy steel tested in oxygenated water at $288^{\circ} \mathrm{C}$

17. Secondary fatigue cracks on descaled surface of A106-Gr B carbon steel and A533-Gr B low-alloy steel specimens 
18. Nucleation of cracks along slip bands, carbide particles, and ferrite/pearlite phase boundaries of carbon steel fatigue specimen

19. Number of cracks along longitudinal section of fatigue specimens tested in different environments.

20. Environmental effects on nucleation of fatigue cracks.

21. Measured CGRs of $\mathrm{CF}-8 \mathrm{M}$ SS in as-received and aged conditions in air at $289^{\circ} \mathrm{C}$ versus calculated CGRs for wrought SS from Section XI of ASME Code.

22. Crack path, fracture surface, and fracture morphology of as-received ITCT specimen of $\mathrm{CF}-8 \mathrm{M}$ cast SS after crack growth experiment in air at $289^{\circ} \mathrm{C}$

23. Fracture surface and fracture morphology of thermally aged 1TCT specimen of $\mathrm{CF}-8 \mathrm{M}$ cast $\mathrm{SS}$ after crack growth experiment in air at $289^{\circ} \mathrm{C}$.

24. Dependence of $\mathrm{CGR}$ of as-received $\mathrm{CF}-8 \mathrm{SS}$ on load ratio in HP oxygenated water at $289^{\circ} \mathrm{C}$.

25. Dependence of CGR of aged CF-8 SS on load ratio in HP oxygenated water at $289^{\circ} \mathrm{C}$

26. Dependence of CGR of aged $\mathrm{CF}-8 \mathrm{M}$ SS on load ratio in HP oxygenated water at $289^{\circ} \mathrm{C}$

27. Dependence of CGR of aged CF-8 SS on DO concentration of HP water at $289^{\circ} \mathrm{C}$

28. Dependence of CGR of aged CF-8 SS on ECP of Type 304 SS in HP water at $289^{\circ} \mathrm{C}$ 30

29. Dependence of ECP of Type 304 SS on DO concentration of HP water from CGR tests on cast SS specimens at $289^{\circ} \mathrm{C}$

30. Dependence of CGR of aged $\mathrm{CF}-8$ SS on $\mathrm{K}_{\max }$ in $\mathrm{HP}$ oxygenated water at $289^{\circ} \mathrm{C}$

31. Crack path, fracture surface, and fracture morphology of as-received 1TCT specimen of $\mathrm{CF}-8$ cast SS after crack growth experiment in HP water at $289^{\circ} \mathrm{C}$

32. Fracture surface and fracture morphology of thermally aged 1TCT specimen of $\mathrm{CF}-8$ cast $\mathrm{SS}$ after crack growth experiment in air at $289^{\circ} \mathrm{C}$

33. Fracture surface and fracture morphology of thermally aged 1TCT specimen of $\mathrm{CF}-8 \mathrm{M}$ cast $\mathrm{SS}$ after crack growth experiment in $\mathrm{HP}$ water at $289^{\circ} \mathrm{C}$.

34. Percent IGSCC vs. fluence for HP and CP Type 304 SS BWR specimens from SSRT tests at $289^{\circ} \mathrm{C}$ in simulated BWR water.

35. Auger peaks from minor impurity elements in typical AES spectra obtained from BWR specimens of Type 304 SS irradiated to $\approx 2 \times 10^{21} \mathrm{n} \cdot \mathrm{cm}^{-2}$ 
36. Intensities of $F$ signal from ductile, intergranular, and faceted fracture surfaces of CP and HP Type 304 SS BWR specimens Irradiated to $\approx 2 \times 10^{21} \mathrm{n} \cdot \mathrm{cm}^{2}$

37. Intensities of $\mathrm{V}$ signal from ductile, intergranular, and faceted fracture surfaces of CP and HP Type 304 SS BWR specimens irradiated to $\approx 2 \times 10^{21} \mathrm{n} \cdot \mathrm{cm} \mathrm{r}^{2}$

38. Grain-boundary concentration of F and V vs. \% IGSCC measured from SSRT tests of BWR neutron-absorber tubes and control-blade sheath irradiated to $\approx 2 \times 10^{21} \mathrm{n} \cdot \mathrm{cm}^{2}$

39. Relative Auger electron intensities of $\mathrm{F}$ from ductile-fracture regions and from $\mathrm{Cu}$-rich precipitates in IASCC-resistant HP304 SS neutron-absorber tubes Irradiated to $2.0 \times 10^{21} \mathrm{n} \cdot \mathrm{cm}^{-2}$, Indicating that $\mathrm{F}$ atoms are trapped at $\mathrm{Cu}$-rich precipitates

40. Effects of ECP and DO on susceptibility of irradiated austenitic SS to LASCC in SSRT tests: \%IGSCC vs. ECP; \%IGSCC vs. DO; and average CGR vs. ECP

41. Schematic of irradiation vehicle, fuel rods, and capsule loading in Halden HBWR.

42. Specimen encapsulation and stacking in irradiation vehicle in Halden HBWR.

43. Dimensions of SSRT and CT specimens being irradiated in Halden HBWR 44

44. Schematic of $J-R$ fracture-toughness facility for tests on miniature $C T$ specimens of austenitic SS irradiated in Halden HBWR

\section{Tables}

1. Chemical composition of ferritic steels for fatigue tests ......................................................

2. Average room-temperature tensile properties of ferritic steels........................................... 4

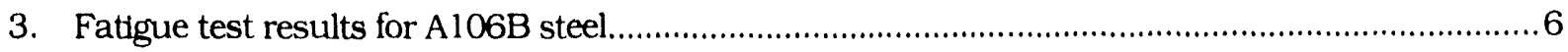

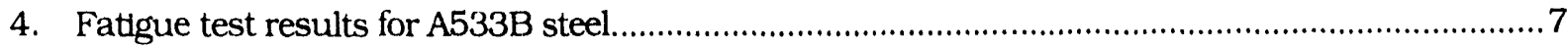

5. Chemical composition and ferrite content of cast SSs for corrosion fatigue tests in simulated BWR water

6. Crack growth results for as-received and aged $\mathrm{CF}-8 \mathrm{M}$ cast SS IT-compacttension specimens under cyclic loading in air at $289^{\circ} \mathrm{C}$.

7. Crack growth rates for $\mathrm{CF}-8 \mathrm{M}$ and $\mathrm{CF}-8$ cast $\mathrm{SS} 1 \mathrm{~T}$-compact tension specimens under cyclic loading in $289^{\circ} \mathrm{C}$ water

8. Chemical composition and fluence of HP and CP Type 304 SS BWR components.

9. Composition of SSRT and CT specimens of austenitic SSs irradiated to $\approx 0.43 \times 10^{21} \mathrm{n} \cdot \mathrm{cm}^{-2}$ in Halden reactor 


\section{Executive Summary}

Fatigue of Ferritic Piping and Pressure Vessel Steels

Plain carbon steels are used extensively in PWR and BWR nuclear steam supply systems as piping and pressure vessel materials. The steels of interest for these applications include A106-Gr B and A333-Gr 6 for seamless pipe and A302-Gr B, A508-2, and A533-Gr $B$ plate for pressure vessels. Fatigue tests have been conducted on A106-Gr B carbon steel and A533-Gr B low-alloy steel to evaluate the effects of oxygenated water on fatigue life of these steels. For both steels, environmental effects are modest in PWR water at all strain rates. The data confirm the strong dependence of fatigue life on dissolved oxygen (DO) concentration in water and strain rate. The effect of strain rate on fatigue life saturates at some low value, e.g. between 0.0004 and $0.001 \% / \mathrm{s}$ in water containing $\approx 0.8 \mathrm{ppm}$ DO. The data suggest that the saturation value of strain rate may vary with DO and sulfur content of the steel. Although the cyclic stress-strain and cyclic-hardening behavior of carbon and low-alloy steels is distinctly different, the degradation of fatigue life of these two steels with comparable sulfur levels is similar. The carbon steel exhibits pronounced dynamic strain aging, whereas strain-aging effects are modest in the low-alloy steel. Environmental effects on nucleation of fatigue cracks have also been investigated. The results suggest that the high-temperature oxygenated water has little or no effect on crack nucleation.

\section{Environmentally Assisted Cracking of Cast Stainless Steels}

Crack growth rate (CGR) tests have been conducted on fracture-mechanics specimens of CF-8M grade of cast stainless steel (SS) in as-received and thermally aged conditions in air at $289^{\circ} \mathrm{C}$ to provide baseline information for comparison with results for wrought SSs in air in Section XI of the ASME Code and in oxygenated water. The results indicated that. long-term thermal aging had no effect on CGRs of CF-8M SS in air. The experimental data were consistent with predictions from the ASME Code at rates of $\geq 5 \times 10^{-10} \mathrm{~m} \cdot \mathrm{s}^{-1}$, but were below Code predictions by one order of magnitude at lower rates.

Additional crack growth tests have been conducted on fracture-mechanics specimens of $\mathrm{CF}-8$, and $\mathrm{CF}-8 \mathrm{M}$ grades of cast $\mathrm{SS}$ in as-received and thermally aged conditions to characterize material, loading, and environmental conditions that can produce susceptibility to environmentally assisted cracking in these steels. The CGRs of thermally aged $\mathrm{CF}-8 \mathrm{M}$ specimens showed greater environmental enhancement than did as-received and thermally aged $\mathrm{CF}-8$ specimens with virtually the same carbon and ferrite contents in high-purity (HP) oxygenated water at load ratios between 0.3 and 0.95 . Dependence of the CGRs of thermally aged CF-8 SS on DO concentration (0.002-8 ppm) and electrochemical potential of Type 304 SS (-565 to $250 \mathrm{mVSHE})$ in HP water was determined at a load ratio of 0.95 , a rise time of $12 \mathrm{~s}$, and $\mathrm{K}_{\max }$ of 35-38 MPa $\mathrm{m}^{1 / 2}$. The CGRs increase rapidly with DO concentration over a relatively narrow range $(\approx 0.05-0.2 \mathrm{ppm})$ and become virtually independent of DO at $>0.2 \mathrm{ppm}$. The CGRs at high DO concentrations indicate that the air curve is frequently nonconservative, but the data are bounded by modified correlations for wrought SSs in water at $289^{\circ} \mathrm{C}$.

Metallographic evaluation of the specimens after the experiments indicated that the mode of cracking in $\mathrm{CF}-8 \mathrm{M}$ specimens in air was transgranular and that the crack path in all specimens in water favored the ferrite/austenite phase boundaries in the materials. 
Although significant grain-boundary $\mathrm{Cr}$ depletion can play an important role in IASCC of thermally sensitized and irradiated components, we suspect that another primary process that involves trace impurity elements, which are not spr-ited in the ASTM specifications. may contribute to IASCC of solution-annealed materials. These elements are typically associated with iron- and steel-making processes and with fabrication of the actual components, i.e., elements associated with flux compounds, cutting agents, recycled scrap, and strengthening materials. Results of grain-boundary chemical analysis by Auger electron spectroscopy of specimens obtained from Type 304 SS components irradiated in operating BWRs were examined to determine the role of trace elements. Surprisingly, the susceptibility of specimens obtained from irradiated BWR components to intergranular cracking correlates well with the grain-boundary concentrations of $F$ and $V$. Fluorine apparently criginates from welding electrodes or fluorspar, a compound frequently used as flux material by many producers of iron and steels (or from recycling of F-containing steel scrap), whereas $\mathrm{V}$ originates from ferrovanadium, a strengthening compound used extensively by most steel makers. Fluorine seems to be trapped by certain types of precipitates, indicating an important role of precipitation in austenitic SSs.

Sixteen SSRT and four CT specimens of austenitic SS alloys were shipped to ANL after irradiation to a fluence of $\approx 0.43 \times 10^{21} \mathrm{n} \cdot \mathrm{cm}^{-2}(\mathrm{E}>1 \mathrm{MeV})$ in the Halden HBWR. A J-R test facility is being assembled to measure the fracture toughness of the miniature $C T$ specimens. Specimens are loaded by an MTS hydraulic system that operates under strain control, and crack length will be monitored by the reversing DC potential-drop method. The facility has been designed for conversion to a crack-growth-testing system in hightemperature water. 


\section{Acknowledgments}

W. F. Burke, D. A. Donahue, G. Dragel, T. M. Galvin, D. R. Perkins, D. O. Pushis, J. C. Tezak, and P. L. Torres contributed to the experimental effort in this program. The BWR components and the stainless steel specimens irradiated in the Halden Reactor were obtained through the assistance of Dr. A. J. Jacobs of General Electric Company and Mr. K. D. Knudsen of the Halden Reactor Project, Norway, respectively. This work is part of a program entitled "Environmentally Assisted Cracking and Fatigue in LWR Systems," sponsored by the Office of Nuclear Regulatory Research. U.S. Nuclear Regulatory Commission, under FIN Number A22 12: Program Manager: Dr. J. Muscara. 


\section{Introduction}

Fatigue and environmentally assisted cracking (EAC) of piping, pressure vessels, and core components in light water reactors (LWRs) are important concerns as extended reactor lifetimes are envisaged. The degradation processes in U.S. reactors include fatigue of austenitic stainless steel (SS) in emergency core cooling systems* and pressurizer surge line ${ }^{* *}$ piping in pressurized water reactors (PWRs), intergranular stress corrosion cracking (IGSCC) of austenitic SS piping in boiling water reactors (BWRs), and propagation of fatigue or stress corrosion cracks (which initiate in sensitized SS cladding) into low-alloy ferritic steels in BWR pressure vessels."** Similar cracking has also occurred in upper-shell-totransition-cone girth welds in PWR steam generator vessels, ${ }^{+}$and cracks have been found in steam generator feedwater distribution piping. ${ }^{++}$Occurrences of mechanical-vibrationand thermal-fluctuation-induced fatigue fallures in LWR plants in Japan have also been documented.1 Another concern is fallure of reactor-core internal components after accumulation of relatively high fluence. ${ }^{+++}$The general pattern of the observed fallures indicates that as nuclear plants age and the neutron fluence increases, many apparently nonsensitized austenitic materials become susceptible to intergranular failure by a degradation process commonly known as irradiation-assisted stress corrosion cracking (IASCC). Some of these failures have been reported for components subjected to relatively low or negligible stress levels, e.g., control-blade sheaths and handles and instrument dry tubes of BWRs. Although most failed components can be replaced, some safety-significant structural components, such as the BWR top guide, shroud, and core plate, would be very difficult or impractical to replace. Research during the past six months has focused on (a) fatigue of ferritic steels used in piping, steam generators, and pressure vessels; (b) EAC of cast austenitic SSs; and (c) LASCC in high- and commercial-purity (HP and CP) Type 304 SS specimens from control-blade absorber tubes and a control-blade sheath used in operating BWRs.

\section{Fatigue of Ferritic Steels}

Plain carbon and low-alloy steels are used extensively in PWR and BWR steam supply systems as piping and pressure vessel materials. The steels of interest in these applications include A106-Gr B and A333-Gr 6 for seamless pipe and A302-Gr B, A508-2, and A533Gr B plate for pressure vessels. The ASME Boller and Pressure Vessel Code Section III, ${ }^{2}$ Subsection NB, contains rules for the construction of nuclear power plant Class 1 components. It recognizes fatigue as a possible mode of failure in pressure vessel steels and piping materials. Figure I-90 of Appendix I to Section III specifies the fatigue design curves for the applicable structural materials. However, Section III, Subsection NB-3121 of the

" USNRC Information Notice No. 88-08. "Thermal Stresses in Piping Connected to Reactor Coolant Systems," June 22, 1988; Supplement 1. June 24, 1988; Supplement 2. August 4, 1988; Supplement 3, April 11. 1989.

** USNRC Information Notice No. 88-11. "Pressurizer Surge Line Thermal Stratification," December 20.1988.

*** USNRC Information Notice No. 90-29, "Cracking of Cladding in Its Heat-Affected Zone in the Base Metal of a Reactor Vessel Head," April 30, 1990.

+ USNRC Information Notice No. 90-04, "Cracking of the Upper Shell-to-Transition Cone Girth Welds in Steam Generators." January, 26, 1990.

++ USNRC Information Notice No. 91-19, "Steam Generator Feedwater Distribution Piping Damage," March 12. 1991.

+++ USNRC Information Notice No. 93-79. "Core Shroud Cracking at Beltline Region Welds in Boiling-Water Reactors," September 1993. 
Code states that environmental effects on fatigue resistance of the material are not explicitly addressed in these design fatigue curves. Therefore, there is some uncertainty relating to the effects of environment on fatigue resistance of materials for all operating PWR and BWR plants whose primary coolant pressure boundary components are constructed to Section III of the Code.

The current Code design curves are based primarily on strain-controlled fatigue tests of small polished specimens in air at room temperature. ${ }^{3}$ To obtain the Code fatigue design curves, best-fit curves to the experimental data were decreased by a factor of 2 on stress or a factor of 20 on cycles, whichever was more conservative at each point. The factors were intended to account for uncertainties in translating the experimental data of laboratory test specimens to actual reactor components. The factor of 20 on cycles is the product of three subfactors: 2.0 for scatter of data (minimum to mean), 2.5 for size effects, and 4.0 for surface finish, atmosphere, etc. ${ }^{4}$ "Atmosphere" was intended to reflect the effects of an industrial environment rather than the controlled environment of a laboratory. The effects of the coolant environment are not explicitly addressed in the Code design curves.

Recent fatigue strain vs. life (S-N) data from the U.S. 5-14 and Japan ${ }^{15-1 \%}$ illustrate potentially significant effects of LWR environments on the fatigue resistance of carbon and low-alloy steels. In some cases, failures were observed below the ASME Code fatigue design curve. These results raise the issue of whether the fatigue design curves in Section III are appropriate for the purposes intended and whether they adequately account for environmental effects on fatigue behavior. The factors of 2 and 20 applied to the mean-data curve may not be as conservative as originally intended.

The primary sources of U.S. data on fatigue of ferritic steel in LWR environments are the data obtained by General Electric Co. (GE) in a test loop at the Dresden 1 reactor, 5,6 tests performed by GE/Electric Power Research Institute (EPRI), 7.8 the work of Terrell at Mechanical Engineuring Associates (MEA),9-11 and the present work at Argonne National Laboratory (ANL).12-14 Nearly all these data are on carbon steels. The data from Japan have been compiled in the data base JNUFAD* for "Fatigue Strength of Nuclear Plant Components." The results for A508-Cl 3 low-alloy steel and A333-Gr, 6 carbon steel have been published by Higuchi and Iida ${ }^{15}$ and lida et al. ${ }^{16}$ and for forged A508-Cl 3 and rolled A533-Gr B low-alloy steels by Nagata et al. 17

Several key variables that influence fatigue S-N. behavior of carbon and low-alloy steels can be identified from the available data. The, existing data may be divided into three groups on the basis of environment; air, and water having either modest or significant effects on life. In air, only steel type and temperature influence fatigue $\mathrm{S}-\mathrm{N}$ behavior, although the effect is relatively small. The fatigue lives of carbon steels are $\approx 30 \%$ lower than those of low-alloy steels. For both steels, an increase in temperature from room temperature $(\mathrm{RT})$ to $300^{\circ} \mathrm{C}$ decreases life by a factor of $\approx 2$ and strain rate has little or no effect on low-cycle fatigue (LCF), i.e., at high strain ranges. Strain rates may be important for high-cycle fatigue ( $\mathrm{HCF})$, i.e., at low strain ranges, because of dynamic strain aging.

* Private communication from M. Higuchi, Ishikawajima-Harima Heavy Industries Co., Japan. to M. Prager of the Pressure Vessel Research Council (PVRC), 1992. The old database "FADAL" has been revised and renamed "JNUFAD." 
However, the existing data are inadequate to establish the effect of strain rate on $\mathrm{HCF} ; \mathrm{S}-\mathrm{N}$ data at low strain range and low strain rate are very limited.

The data indicate that environmental effect on fatigue life can $r$ s significant when all of the following variables exceed a threshold value: (a) sulfur content of the steel is $>0.003$ wt. $\%$, (b) temperature is $\geq 150^{\circ} \mathrm{C}$. (c) concentration of dissolved oxygen (DO) in the water is $\geq 0.05 \mathrm{ppm}$, and (d) loading rate during the tensile-going loading cycle is $\leq 1 \% / \mathrm{s}$. The actual threshold values for a specific variable may vary with material and environmental conditions. For example, a sulfur content of $\geq 0.010 \%$ may be needed for environmental effects at $0.1 \mathrm{ppm} D O$, whereas a sulfur content of $\approx 0.005 \%$ may be sufficient at $1 \mathrm{ppm} \mathrm{DO}$. The results also indicate that environmental effects for carbon and low-alloy steels are the same for comparable sulfur levels. ${ }^{14}$

Fatigue data that satisfy all of the above threshold conditions belong to the third group. namely, water having a significant effect on life. When any one of the four threshold conditions is not satisfied, e.g., at very low DO levels characteristic of PWRs or BWRs with hydrogen-water chemistry or at temperatures $<150^{\circ} \mathrm{C}$, environmental effects on fatigue life are modest.

Fatigue life decreases rapidly as DO increases over a narrow range of $\approx 0.05-0.5 \mathrm{ppm}$. but further increases above $0.5 \mathrm{ppm}$ cause only a modest decrease in life. 15.16 In oxygenated water, fatigue life depends strongly on temperature and strain rate. At a given strain rate, fatigue life increases by a factor of 5 or more as temperature decreases from 290 to $200^{\circ} \mathrm{C}$. For the same environment and the same strain range, lives can vary by a factor of $\approx 50$, depending on the strain rate. The results indicate that for both carbon and low-alloy steels, the effect of strain rate on fatigue life saturates at $\approx 0.001 \% / \mathrm{s}$. 14 . Based on existing fatigue $\mathbf{S}-\mathbf{N}$ data, ANL has developed interim fatigue design curves that take into account temperature, DO levels in water, sulfur level in steel, and strain rate. ${ }^{18}$

\subsection{Technical Progress (O. K. Chopra, W. F. Michaud, W. J. Shack, and W. K. Soppet)}

The objectives of this task are to (a) conduct fatigue tests on carbon and low-alloy steels under conditions where information is lacking in the existing S-N data base, (b) establish the effects of material and loading variables on environmentally assisted reduction in fatigue life, and (c) validate and update the proposed interim fatigue design curves. Fatigue tests are being conducted on A106-Gr B carbon steel and A533-Gr B low-alloy steel in water and in air at $288^{\circ} \mathrm{C}$. The experimental effort during the present reporting period focused on the effects of various material and test variables, e.g., composition, strain rate, strain range, and surface micropitting on fatigue life of A106-Gr B carbon steel and A533-Gr B low-alloy steel.

\subsubsection{Experimental}

Low-cycle fatigue tests are being conducted on A106-Gr B carbon steel and A533-Gr B low-alloy steel with an MTS closed-loop electrohydraulics máchine. The A533-Gr B material was obtained from the lower head of the Midland reactor vessel, which was scrapped before the plant was completed. The A106-Gr B material was obtained from a 508-mm-diameter schedule 140 pipe fabricated by the Cameron Iron Works, Houston, TX. The chemical compositions of the two materials are given in Table 1, and average RT tensile properties are given in Table 2. 
Table 1. Chemical composition (wt.\%) of ferritic steels for fatigue tests

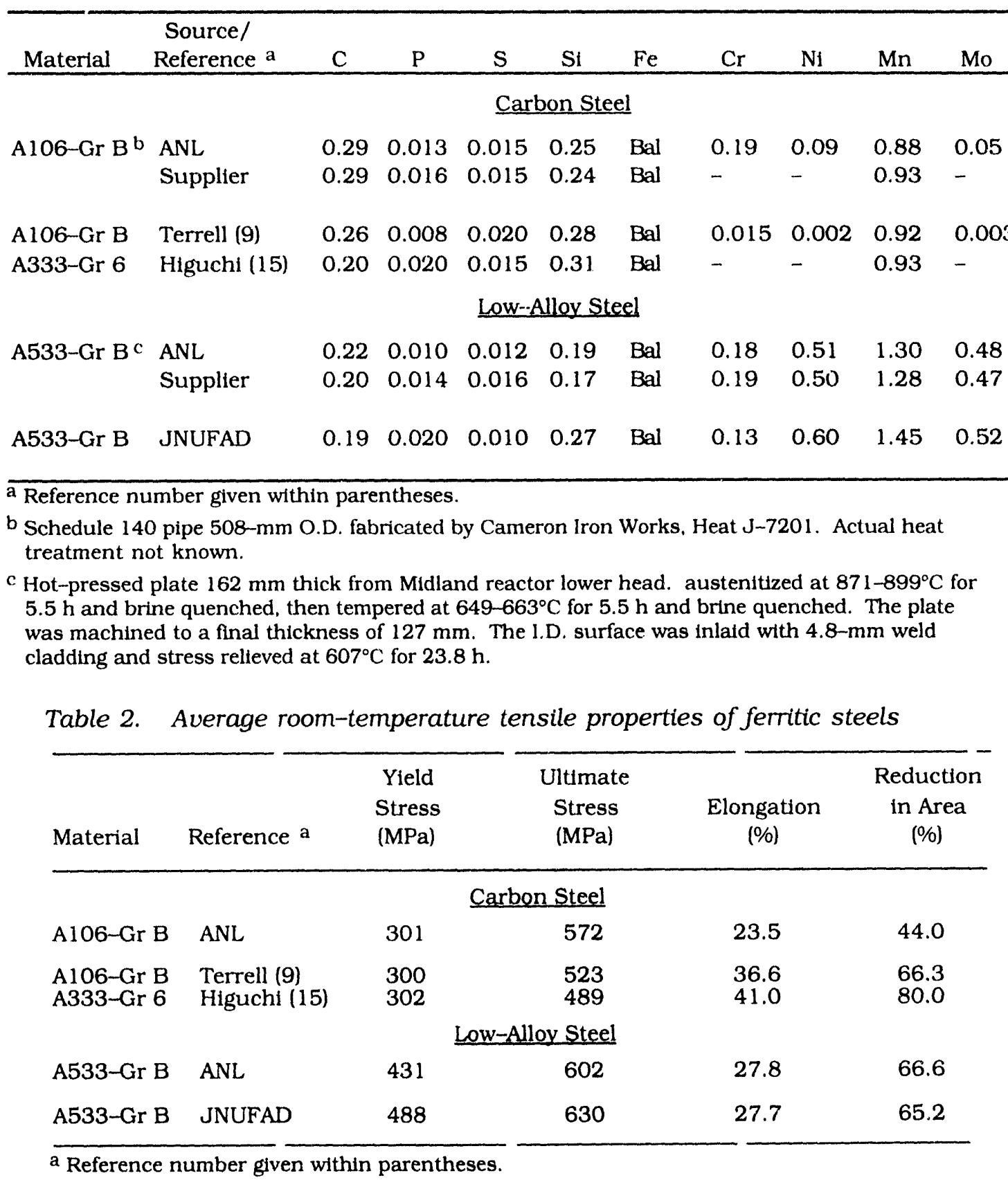

Smooth cylindrical specimens with 9.5-mm diameter and 19-mm gage length were used for the fatigue tests. All tests were conducted at $288^{\circ} \mathrm{C}$ with fully reversed axial loading (i.e., strain ratio $R=-1$ ) and a triangular or sawtooth wave form. Unless otherwise mentioned, the strain rate for the triangular wave and fast-loading half of the sawtooth wave was $0.4 \% / \mathrm{s}$. Tests in water were performed under stroke control where the specimen strain was controlled between two locations outside the autoclave. Tests in air were performed under strain control with an axial extensometer; specimen strain between the two locations in the water tests was also recorded. Information from the air tests was used to determine the stroke required to maintain constant strain in the specimen gage length for tests in water; stroke was gradually increased during the test to maintain constant strain 
in the specimen. A detailed description of the test facility and procedure have been presented earlier. 14

\subsubsection{Air Tests}

The fatigue results on A106-Gr B and A533-Gr B steels are summarized in Tables 3 and 4 , respectively. The total strain range $\left(\Delta \varepsilon_{t}\right)$ vs. fatigue life $\left(N_{25}\right)$ curves for the carbon and low-alloy steels in air are shown in Figs. 1 and 2, respectively. Fatigue life is defined as the number of cycles for the peak tensile stress to drop $25 \%$ from its initial value. Results from other investigations 9,15 on similar steels with comparable composition, in particular sulfur content, and the ASME Section III mean-data curves are also included in the figures. The results indicate that for both steels, strain rate has no effect on fatigue life in air. The data for A106-Gr B steel are in excellent agreement with results obtained by Terrell ${ }^{9}$ on A106Gr B steel, but are lower by a factor of $\approx 5$ than those obtained by Higuchi and Iida 15 on A333-Gr 6 steel. Also, the data for A106-Gr B steel are below the ASME mean-data curve for carbon steel at room temperature at high strain ranges (by a factor of 3 ), but are above the ASME mean curve at low strain ranges. The results for A533-Gr B steel show good agreement with the JNUFAD data on A533-Gr B steel and the ASME mean-data curve for low-alloy steel at room temperature.

\subsubsection{Alloy Composition}

The cyclic-hardening behavior of carbon and low-alloy steels is consistent with their microstructure. The A106-Gr B steel, with a pearlitic structure and low yield stress, exhibits rapid hardening during the initial 100 cycles of fatigue life. The extent of hardening increases with applied strain range. In addition, the A106-Gr B carbon steel also exhibits dynamic strain aging, a time-dependent phenomenon caused by interstitial elements dissolved in the ferrite matrix. Consequently. cyclic stress of carbon steel increases significantly with decreasing strain rate, although its fatigue life is not affected. In contrast, the A533-Gr B low-alloy steel consists of a tempered bainitic structure, has a relatively high yield stress, and shows little or no initial hardening. At low strain ranges, the A533-Gr B steel shows cyclic softening during the initial 100 cycles of fatigue life. Because of its tempered bainitic structure, the low-alloy steel exhibits little or no dynamic strain aging.

The effect of strain rate on the cyclic stress-strain curve is quite pronounced in A106Gr B carbon steel because of dynamic strain aging of the material, whereas strain rate has only a modest effect on the cyclic stress-strain curve for A533-Gr B low-alloy steel. For both steels, oxygenated water has no effect on the cyclic stress-strain behavior.

Crack propagation behavior is also different for carbon and low-alloy steels. Micrographs of fatigue cracks along longitudinal sections of A106-Gr B and A533-Gr B steel specimens are shown in Fig. 3. In carbon steel, fatigue cracks propagate preferentially

along the soft ferrite grains. The low-alloy steel exhibits a typical straight fatigue crack that propagates normal to the stress axis. 
Table 3. Fatigue test results for A106B steel

\begin{tabular}{|c|c|c|c|c|c|c|c|c|c|}
\hline $\begin{array}{c}\text { Test } \\
\text { Number }\end{array}$ & Env. ${ }^{a}$ & $\begin{array}{c}\text { Dissolved } \\
\text { Oxygen } \\
\text { (ppb) }\end{array}$ & $\begin{array}{l}\mathrm{pH} \\
\text { at } \mathrm{RT}\end{array}$ & $\begin{array}{c}\text { Cond. } \\
(\mu \mathrm{S} / \mathrm{cm})\end{array}$ & $\begin{array}{c}\text { Tensile } \\
\text { Rateb } \\
(\% / s) \\
\end{array}$ & $\begin{array}{l}\text { Comp. } \\
\text { Rateb } \\
(\% / s)\end{array}$ & $\begin{array}{l}\text { Stress } \\
\text { Range } \\
\text { (MPa) }\end{array}$ & $\begin{array}{c}\text { Strain } \\
\text { Range } \\
(\%)\end{array}$ & $\begin{array}{c}\text { Life } \\
\mathrm{N}_{25} \\
\text { (Cycles) } \\
\end{array}$ \\
\hline \multicolumn{10}{|c|}{ Strain Control Tests } \\
\hline 1498 & Air & - & - & - & 0.4 & 0.4 & 1001.4 & 1.004 & 1.048 \\
\hline 1553 & Air & - & - & - & 0.4 & 0.4 & 921.1 & 0.757 & 3.253 \\
\hline 1615 & Air & - & - & - & 0.04 & 0.4 & 959.8 & 0.755 & 3.873 \\
\hline 1609 & Air & - & - & - & 0.004 & 0.4 & 1026.0 & 0.756 & 3.721 \\
\hline 1673 & Air & - & - & - & 0.004 & 0.4 & 1003.6 & 0.759 & 6.275 \\
\hline 1543 & Air & - & - & - & 0.4 & 0.4 & 818.2 & 0.502 & 14,525 \\
\hline 1638 & Air & - & - & - & 0.4 & 0.4 & 803.0 & 0.440 & $26.728^{c 1}$ \\
\hline 1636 & Air & - & - & - & 0.4 & 0.4 & 749.6 & 0.402 & $34,829 \mathrm{c}^{2}$ \\
\hline 1619 & Air & - & - & - & 0.4 & 0.4 & 741.7 & 0.401 & 37,142 \\
\hline 1621 & Air & - & - & - & 0.01 & 0.4 & 787.1 & 0.403 & 38.128 \\
\hline 1550 & Air & - & - & - & 0.4 & 0.4 & 681.7 & 0.353 & 66.768 \\
\hline 1552 & Air & - & - & - & 0.4 & 0.4 & 680.6 & 0.352 & 93,322 \\
\hline 1644 & Air & - & - & - & 0.004 & 0.4 & 702.0 & 0.364 & $>95,000$ \\
\hline \multicolumn{10}{|c|}{ Stroke Control Tests } \\
\hline 1546 & Air & - & - & - & 0.4 & 0.4 & 975.7 & 0.916 & 1,365 \\
\hline 1612 & Air & - & - & - & 0.004 & 0.4 & 1008.2 & 0.779 & 3.424 \\
\hline 1554 & Air & - & - & - & 0.4 & 0.4 & 896.8 & 0.730 & 3,753 \\
\hline 1548 & Air & - & - & - & 0.4 & 0.4 & 831.9 & 0.545 & 10,632 \\
\hline 1555 & Air & - & - & - & 0.4 & 0.4 & 676.3 & 0.343 & 98,456 \\
\hline 1547 & PWR & 8 & 6.7 & 23.26 & 0.4 & 0.4 & 1010.9 & 0.987 & 692 \\
\hline 1564 & PWR & 12 & 6.6 & 21.74 & 0.4 & 0.4 & 942.0 & 0.769 & 1.525 \\
\hline 1676 & PWR & 2 & 6.5 & 20.83 & 0.4 & 0.4 & 926.7 & 0.741 & 2,230 \\
\hline 1679 & PWR & 3 & 6.5 & 20.41 & 0.004 & 0.4 & 1005.8 & 0.763 & 2,141 \\
\hline 1681 & PWR & 1 & 6.5 & 20.00 & 0.0004 & 0.4 & 1015.7 & 0.764 & 2,672 \\
\hline 1549 & PWR & 8 & 6.7 & 25.64 & 0.4 & 0.4 & 827.0 & 0.533 & 9,396 \\
\hline 1560 & PWR & 12 & 6.6 & 23.73 & 0.4 & 0.4 & 701.3 & 0.363 & 35.190 \\
\hline 1556 & PWR & 8 & 6.6 & 22.73 & 0.4 & 0.4 & 710.9 & 0.360 & 38,632 \\
\hline 1632 & BWR & 800 & 5.8 & 0.11 & 0.4 & 0.4 & 913.3 & 0.740 & 2,077 \\
\hline 1614 & BWR & 400 & 5.9 & 0.11 & 0.004 & 0.4 & 930.4 & 0.786 & 303 \\
\hline 1623 & BWR & 800 & 5.9 & 0.08 & 0.004 & 0.004 & 943.8 & 0.792 & 338 \\
\hline 1616 & BWR & 800 & 5.8 & 0.08 & 0.0004 & 0.4 & 912.8 & 0.799 & 153 \\
\hline 1620 & BWR & 900 & 5.9 & 0.11 & 0.00004 & 0.004 & 943.1 & 0.794 & 161 \\
\hline 1634 & BWR & 800 & 5.8 & 0.16 & 0.4 & 0.4 & 733.2 & 0.400 & 19.318 \\
\hline 1624 & BWR & 800 & 5.9 & 0.10 & 0.004 & 0.4 & 775.7 & 0.456 & 2,276 \\
\hline 1639 & BWR & 800 & 5.9 & 0.09 & 0.004 & 0.4 & 751.6 & 0.418 & 2,951 \\
\hline 1637 & BWR & 900 & 5.9 & 0.11 & 0.4 & 0.4 & 788.0 & 0.470 & $16.622^{\mathrm{c} 3}$ \\
\hline 1643 & BWR & 800 & 6.0 & 0.11 & 0.004 & 0.4 & 698.5 & 0.363 & $>65.000$ \\
\hline
\end{tabular}

a Simulated PWR water contains 2 ppm lithium and $1000 \mathrm{ppm}$ boron

b Values for stroke-control tests are approximate. Actual strain rates range between $\pm 5 \%$ of the listed value.

c Preexposure conditions are as follows:

1. Prior to being tested in air. specimen was fatigued for 570 cycles in oxygenated water with $800 \mathrm{ppb}$ $\mathrm{DO}$ at $0.46 \%$ strain range with sawtooth wave form. 0.004 and $0.4 \% / \mathrm{s}$ strain rates in tension and compression.

2. Specimen oxidized in oxygenated water with $600 \mathrm{ppb}$ DO for $100 \mathrm{~h}$ at $288^{\circ} \mathrm{C}$.

3. Specimen was fatigued for 569 cycles in oxygenated water with $800 \mathrm{ppb}$ DO at $0.46 \%$ strain range with sawtooth wave form, 0.004 and $0.4 \% / \mathrm{s}$ strain rates in tension and compression. 
Table 4. Fatigue test results for A533B steel

\begin{tabular}{|c|c|c|c|c|c|c|c|c|c|}
\hline $\begin{array}{c}\text { Test } \\
\text { Number }\end{array}$ & Env. ${ }^{a}$ & $\begin{array}{l}\text { Dissolved } \\
\text { Oxygen } \\
\text { (ppb) }\end{array}$ & at $\mathrm{RT}$ & $\begin{array}{l}\text { Cond. } \\
(\mu \mathrm{S} / \mathrm{cm})\end{array}$ & $\begin{array}{l}\text { Tensile } \\
\text { Rate }^{\mathrm{b}} \\
(\% / \mathrm{s})\end{array}$ & $\begin{array}{l}\text { Comp. } \\
\text { Rateb } \\
(\% / s)\end{array}$ & $\begin{array}{l}\text { Stress } \\
\text { Range } \\
\text { (MPa) }\end{array}$ & $\begin{array}{l}\text { Strain } \\
\text { Range } \\
(\%)\end{array}$ & $\begin{array}{c}\text { Life } \\
\mathrm{N}_{25} \\
\text { (Cycles) }\end{array}$ \\
\hline \multicolumn{10}{|c|}{ Strain Control Tests } \\
\hline 1508 & Air & - & - & - & 0.4 & 0.4 & 910.9 & 1.002 & 3,305 \\
\hline 1515 & Air & - & - & - & 0.4 & 0.4 & 866.1 & 0.752 & 6.792 \\
\hline 1625 & Air & - & - & - & 0.004 & 0.4 & 887.7 & 0.757 & 4,592 \\
\hline 1629 & Air & - & - & - & 0.4 & 0.4 & 782.9 & 0.503 & $31.243^{\mathrm{cl}}$ \\
\hline 1505 & Air & - & - & - & 0.4 & 0.4 & 767.6 & 0.501 & 31.200 \\
\hline 1576 & Air & - & - & - & 0.004 & 0.4 & 805.8 & 0.503 & 28,129 \\
\hline 1590 & Air & - & - & - & 0.4 & 0.004 & 821.1 & 0.503 & 24.471 \\
\hline 1640 & Air & - & - & - & 0.4 & 0.4 & 710.9 & 0.402 & 65,880 \\
\hline 1517 & Air & - & - & - & 0.4 & 0.4 & 692.5 & 0.353 & $2.053,295$ \\
\hline 1659 & Air & - & - & - & 0.004 & 0.4 & 656.2 & 0.343 & $>114,294$ \\
\hline \multicolumn{10}{|c|}{ Stroke Control Tests } \\
\hline 1521 & Air & - & - & - & 0.4 & 0.4 & 889.4 & 0.910 & 3.219 \\
\hline 1523 & Air & - & - & - & 0.4 & 0.4 & 898.6 & 0.917 & 2,206 \\
\hline 1522 & Air & - & - & - & 0.4 & 0.4 & 905.4 & 0.899 & 3,419 \\
\hline 1524 & Air & - & - & - & 0.4 & 0.4 & 892.3 & 0.950 & 3,714 \\
\hline 1525 & Air & - & - & - & 0.4 & 0.4 & 743.6 & 0.452 & 65,758 \\
\hline 1538 & Air & - & - & - & 0.4 & 0.4 & 708.0 & 0.387 & $>1,000,000$ \\
\hline 1526 & DI & 16 & - & - & 0.4 & 0.4 & 876.4 & 0.873 & 3,332 \\
\hline 1527 & $\mathrm{DI}$ & 17 & 6.0 & - & 0.4 & 0.4 & 752.8 & 0.493 & 10,292 \\
\hline 1528 & $\mathrm{DI}$ & 5 & 5.8 & - & 0.4 & 0.4 & 744.1 & 0.488 & 25,815 \\
\hline 1530 & PWR & 3 & 6.9 & 41.67 & 0.4 & 0.4 & 885.5 & 0.894 & 1,355 \\
\hline 1545 & PWR & 8 & 6.9 & 22.73 & 0.4 & 0.4 & 889.7 & 0.886 & 3.273 \\
\hline 1533 & PWR & 4 & 6.9 & 45.45 & 0.004 & 0.4 & 916.0 & 0.774 & 3,416 \\
\hline 1529 & PWR & 3 & 6.9 & 45.45 & 0.4 & 0.4 & 743.4 & 0.484 & 31,676 \\
\hline 1588 & PWR & 6 & 6.5 & 23.26 & 0.004 & 0.4 & 828.7 & 0.514 & $1 ., 321$ \\
\hline 1605 & PWR & 9 & 6.5 & 23.81 & 0.4 & 0.004 & 785.2 & 0.460 & $>57.443$ \\
\hline 1539 & PWR & 6 & 6.8 & 38.46 & 0.4 & 0.4 & 694.8 & 0.373 & 136,570 \\
\hline 1542 & PWR & 6 & 6.6 & 27.03 & 0.4 & 0.4 & 631.8 & 0.354 & $>1,154,892$ \\
\hline 1645 & BWR & 800 & 6.1 & 0.07 & 0.4 & 0.4 & 831.1 & 0.721 & 2,736 \\
\hline 1626 & BWR & 900 & 5.9 & 0.13 & 0.004 & 0.4 & 910.1 & 0.788 & 247 \\
\hline 1627 & BWR & 800 & 5.9 & 0.10 & 0.004 & 0.4 & 826.8 & 0.534 & 769 \\
\hline 1641 & BWR & 800 & 5.9 & 0.09 & 0.4 & 0.4 & 693.0 & 0.374 & 17.367 \\
\hline 1665 & BWR & 800 & 6.1 & 0.08 & 0.004 & 0.4 & 717.0 & 0.376 & 3.455 \\
\hline 1666 & BWR & 750 & 6.1 & 0.09 & 0.0004 & 0.4 & 728.4 & 0.376 & $>7.000$ \\
\hline 1647 & BWR & 800 & 6.1 & 0.09 & 0.4 & 0.4 & 688.0 & 0.363 & 26.165 \\
\hline 1660 & BWR & 750 & 6.1 & 0.11 & 0.004 & 0.4 & 689.6 & 0.360 & $>83.024$ \\
\hline 1649 & BWR & 700 & 6.3 & 0.08 & 0.4 & 0.4 & 673.4 & 0.352 & 28.710 \\
\hline 1652 & BWR & 700 & 6.1 & 0.09 & 0.4 & 0.4 & 638.1 & 0.328 & 56.923 \\
\hline 1655 & BWR & 750 & 6.1 & 0.10 & 0.4 & 0.4 & 567.6 & 0.298 & $>1,673,954$ \\
\hline
\end{tabular}

a DI: Deionized water; simulated PWR water contains 2 ppm lithium and 1000 ppm boron.

b Values for stroke-control tests are approximate. Actual strain rates are $\pm 5 \%$ of the listed value.

c Preexposure conditions are as follows: 1 . Specimen oxidized in oxygenated water with $600 \mathrm{ppb}$ DO for $100 \mathrm{~h}$ at $288^{\circ} \mathrm{C}$. 

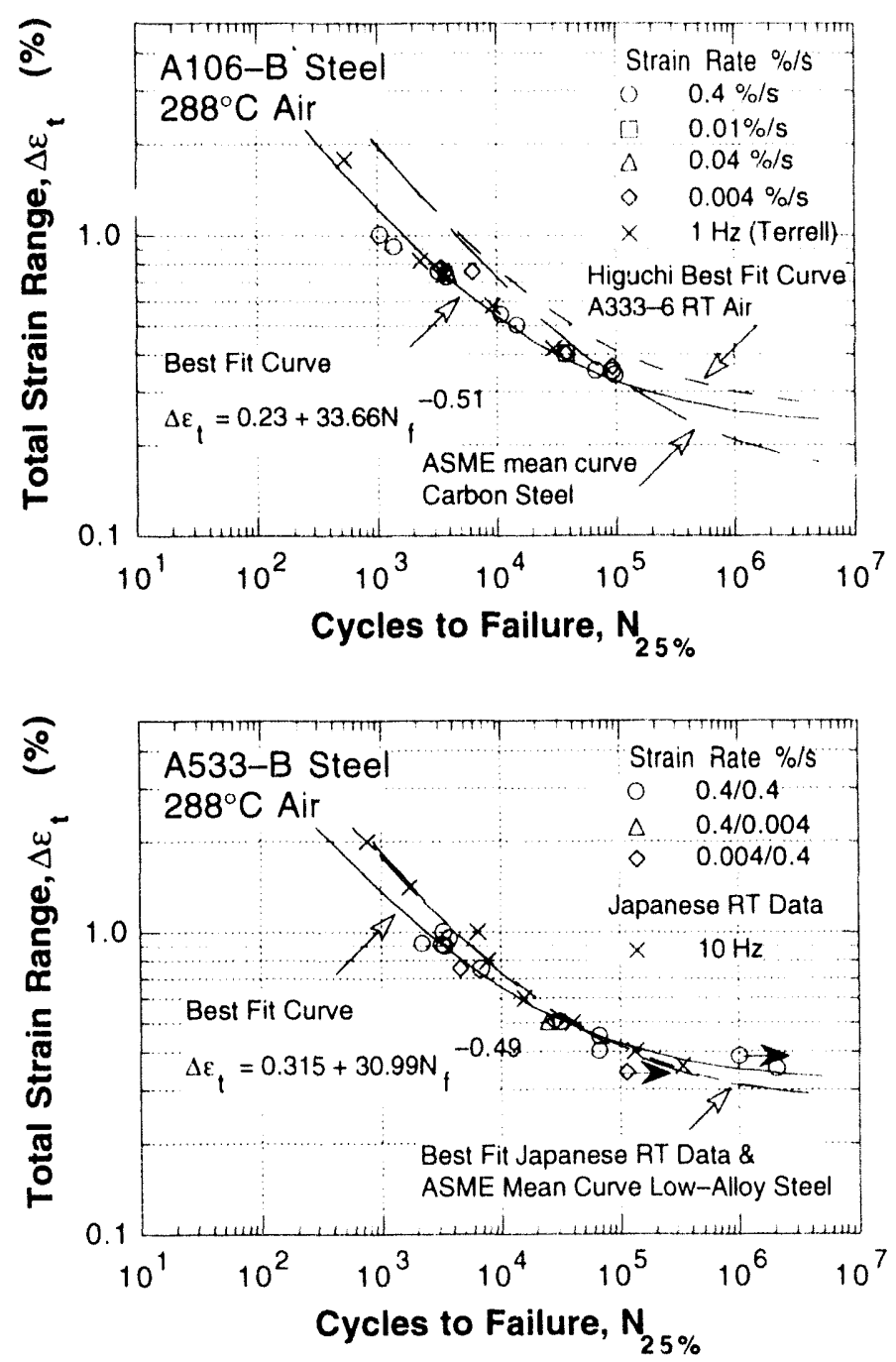

Figure 1.

Total strain range us. fatigue life data for A106-Gr B steel in air

Figure 2.

Total strain range us. fatigue life data for A533-Gr B steel in air

The surface oxide films that develop on carbon or low-alloy steel specimens in air or oxygenated water do not differ significantly. In general, the specimiens tested in air show slight discoloration, whereas the specimens tested in oxygenated water develop a gray/black corrosion scale and are covered with surface deposits. The specimens tested at high DO levels $(0.8 \mathrm{ppm})$ also showed patches of loose brown/red deposit. X-ray diffraction analysis of the surfaces indicated that for both steels, the corrosion scale is primarily magnetite $\left(\mathrm{Fe}_{3} \mathrm{O}_{4}\right)$ in simulated PWR water but also contains some hematite $\left(\mathrm{Fe}_{2} \mathrm{O}_{3}\right)$ after exposure to oxygenated water containing $\approx 0.8 \mathrm{ppm} D O$.

\subsubsection{Simulated PWR Environment}

The total strain range vs. fatigue-life plots for A106-Gr B and A533-Gr B steels in simulated PWR water containing $<10 \mathrm{ppb}$ DO, $1000 \mathrm{ppm}$ boron, and $2 \mathrm{ppm}$ lithium are shown in Figs. 4 and 5, respectively. The results indicate a marginal effect of PWR water on fatigue life at high strain ranges. For both steels. fatigue lives in PWR water are lower by a factor of up to 2 than those in air at a strain range $>0.5 \%$. Fatigue lives in water and air are 
comparable at a strain range $<0.5 \%$. The results also indicate that a decrease in strain rate by three orders of magnitude does not cause an additional decrease in fatigue life. The results for A 106-Gr B steel are consistent with data obtained by Terrell 10.11 in simulated IWR water, where no noticeable effect of strain rate or environment on fatigue life was observed (Fig. 4). The results are also consistent with the data of lida et al. 16 and Prater and Coffin, 19.20 in which the effects of environment were minimal at DO levels of $<0.1-0.2 \mathrm{ppm}$.

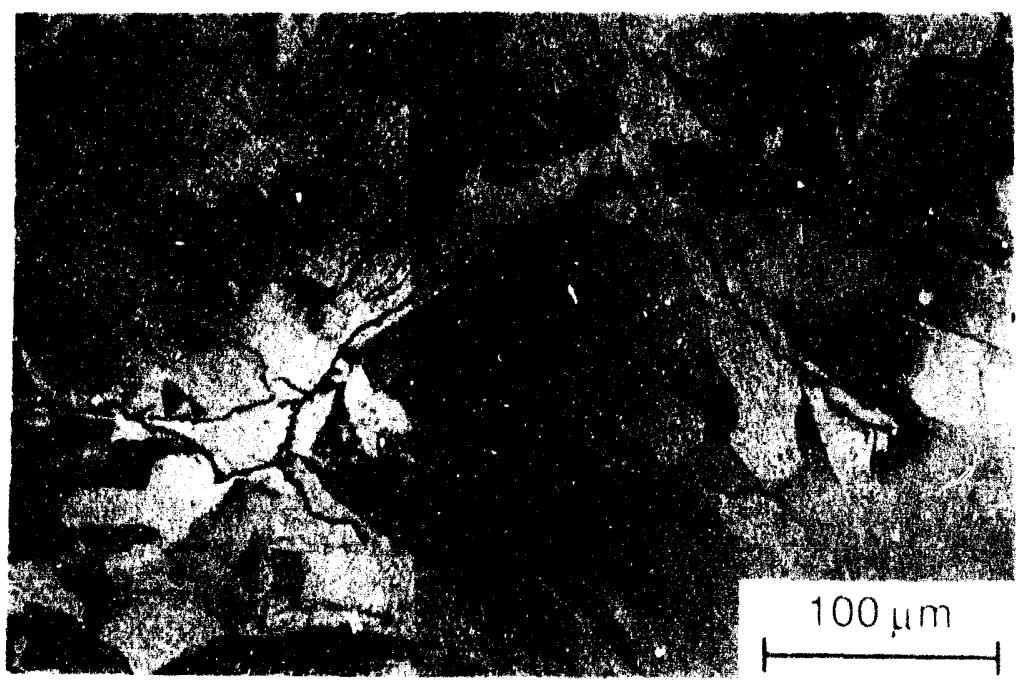

A106-Gr B

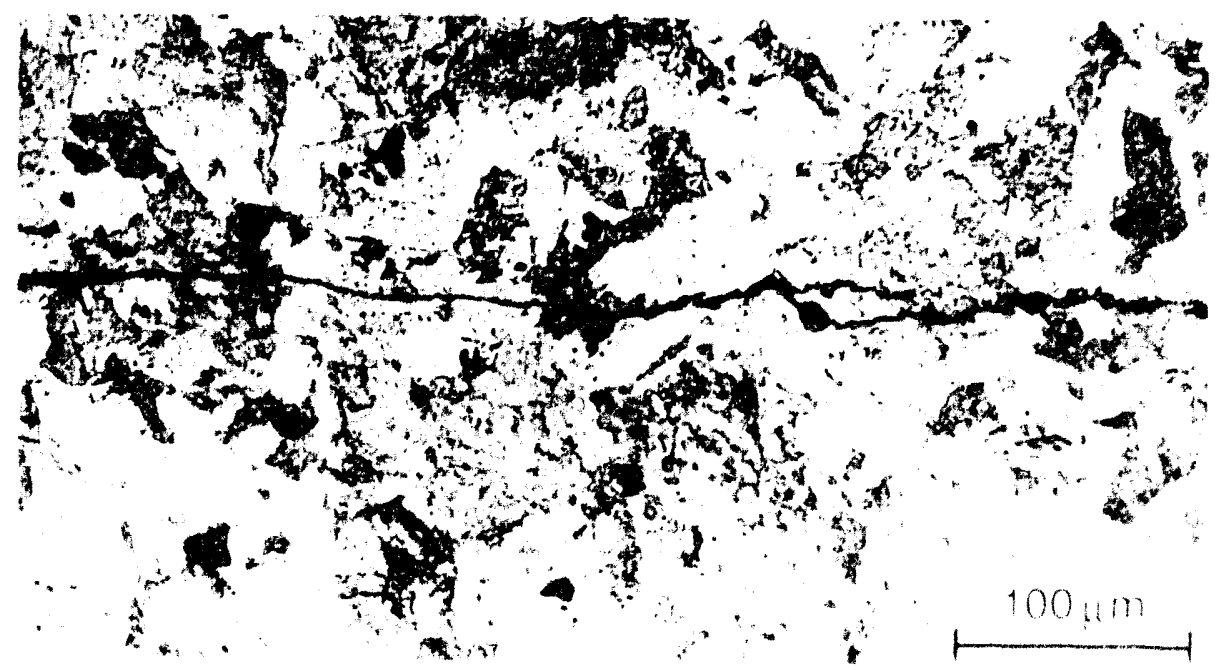

A533-Gr B

Figure 3. Micrographs of typical fatigue cracks along longitudinal sections of A 106-Gr B carbon steel and A533-Gr B lowalloy steel specimens 

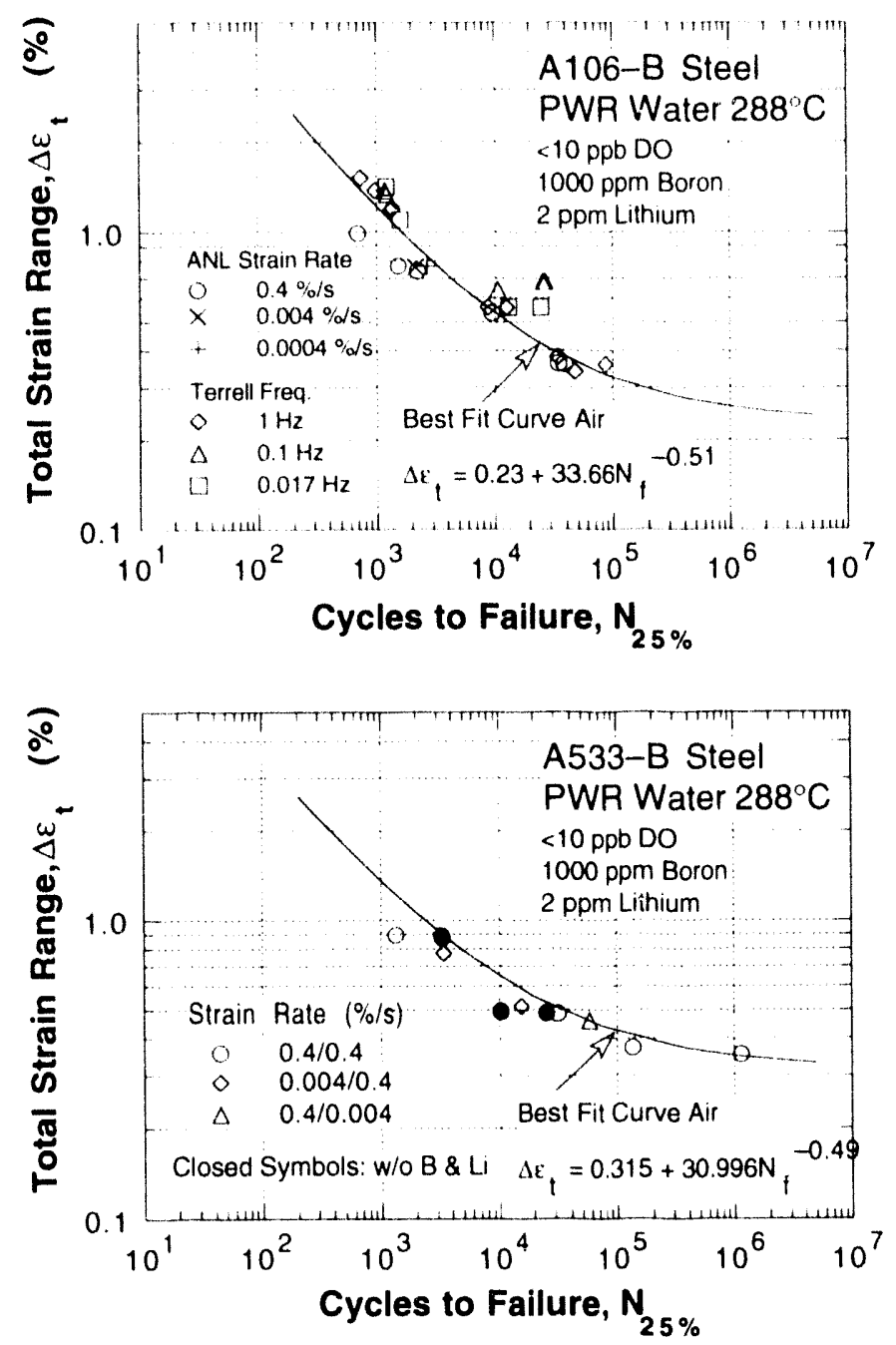

Figure 4.

Total strain range us. fatigue life data for A 106-Gr B steel in PWR water at $288^{\circ} \mathrm{C}$
Figure 5.

Total strain range us. fatigue life data for A533-Gr B steel in PWR water at $288^{\circ} \mathrm{C}$

\subsubsection{Oxygenated Water}

Environmental effects on fatigue life are significant at high DO levels. Total strain range vs. fatigue-life plots for A 106-Gr B and A533-Gr B steels in water containing $=0.8 \mathrm{ppm}$ DO are shown in Figs. 6 and 7, respectively. For A 106-Gr B steel, fatigue tests were conducted at a total strain range of $\approx 0.75 \%$ with a sawtooth wave form and tensile strain rate between 0.4 and $0.00004 \% / \mathrm{s}$; the compressive strain rate was $0.4 \% / \mathrm{s}$ in most of the tests. The results indicate that fatigue life decreases rapidly with decreasing strain rate and saturates at a strain rate between 0.001 and $0.0004 \% / \mathrm{s}$. Compared with tests in air. fatigue life in oxygenated water is lower by factors of 2.10 , and 20 at strain rates of 0.4 , 0.004 , anc $0.0004 \% / \mathrm{s}$, respectively. A further decrease in strain rate to $0.00004 \% / \mathrm{s}$ does not cause an additional decrease in fatigue life. The relative reduction in fatigue life at a total strain range of 0.75 or $0.4 \%$ is the same. The results also indicate that only the slow tensile-strain cycle is responsible for environmentally assisted reduction in fatigue life. Two fatigue tests on A 106-Gr B steel at a strain range of $\approx 0.75 \%$, one with a sawtooth wave form (i.e., 0.004 and $0.4 \% / \mathrm{s}$ strain rates, respectively, during the tensile and compressive half of the strain cycle) and the other with a triangle wave form (i.e., $0.004 \% / \mathrm{s}$ constant strain rate), show identical fatigue lives (Fig. 6). 


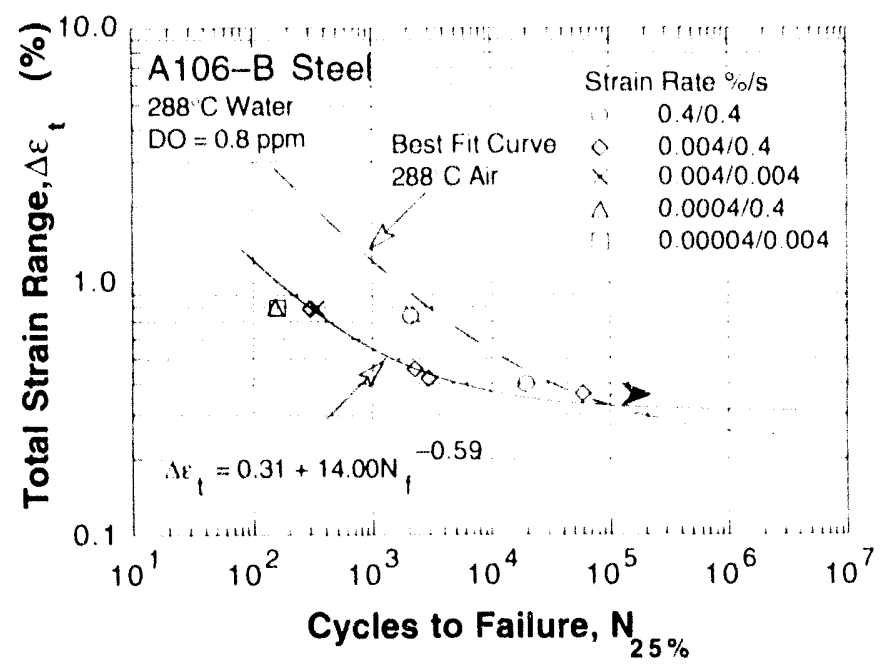

Figure 6.

Total strain range 's. fatigue? lịe data for A 106-Gr B steel in high-oxygen waler at $288^{\circ} \mathrm{C}$

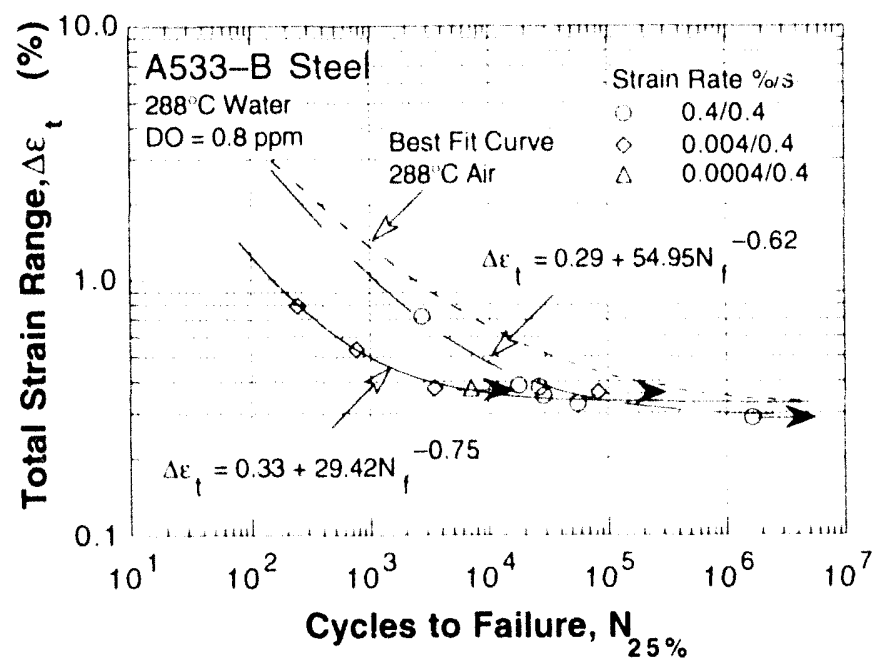

Figure 7.

Total strain range us. fatigue life data for A533-Gr B steel in highoxygen water at $288^{\circ} \mathrm{C}$

Low-alloy A533-Gr B steel shows identical behavior; for similar test conditions, the absolute values of fatigue life are comparable to those for A106-Gr B carbon steel. However. because life in air for A533-Gr B steel is greater than that for A 106-Gr B steel, the relative reduction in life for the low-alloy steel is larger than that for carbon steel. This is particularly true at low strain range $(0.4 \%)$, where even at the high-strain-rate fatigue life is lower by a factor of 10 than in air (Fig. 7).

\subsubsection{Strain Rate}

Fatigue life in exhibits a strong dependence on strain rate and DO concentration in water. Although the microstructures and cyclic-hardening behavior of the Al06-Gr B carbon steel and A533-Gr B low-alloy steel are significantly different, there is little or no difference in environmental degradation of fatigue life of these steels. The relative fatigue lives of several heats of carbon and low-alloy steels with varying sulfur content are plotted as a function of strain rate in Figs. 8 and 9 . Relative fatigue life is the ratio of life in water and life of that specific heat in air. 

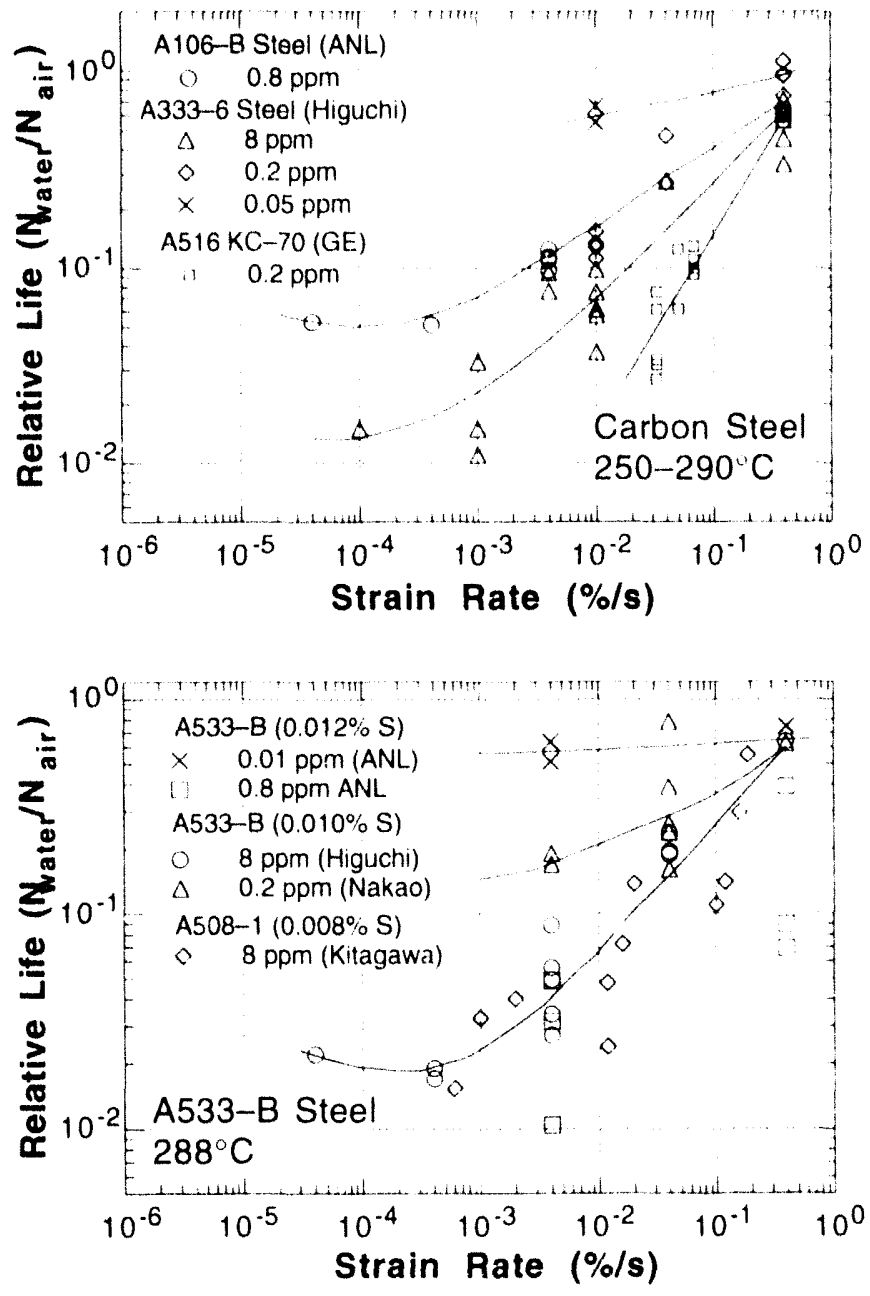

Figure 8.

Relative fatigue life of A $106-\mathrm{Gr} B$ carbon steel at different levels of DO and strain rates
Figure 9.

Relative fatigue life of A533-Gr B low-alloy steel at different levels of $D O$ and strain rates

The results indicate that the reduction in fatigue life depends not only on strain rate but also on DO in water and sulfur content in the steel. Environmental effects increase with decreasing strain rates and increasing levels of $\mathrm{DO}$ and sulfur. For example, the maximum reduction in fatigue life for the A106-Gr B and A333-Gr 6 carbon steels with a similar sulfur content is a factor of 2 at $\leq 0.05 \mathrm{ppm}$ DO and a factor of 50 or more at $8 \mathrm{ppm}$ DO. Fatigue lives at intermediate values of DO are between these limits.

However, data obtained on A516-Gr 70 carbon steel (0.033 wt.\% sulfur) by General Electric Co. (GE) in a test loop at the Dresden 1 reactor 4.5 show a different trend. For this steel, the reduction in fatigue life at $0.2 \mathrm{ppm}$ DO (square data points in Fig. 8) is greater by a factor of $\approx 2$ than that for the A 106-Gr B steel at $0.8 \mathrm{ppm}$ DO and for A333-Gr 6 steel at $0.2 \mathrm{ppm}$ DO. The difference may be attributed to the higher sulfur content in the A516Gr 70 steel. Similar effects of DO and sulfur content are observed for the low-alloy steels. The results also indicate that for both steels, the effect of strain rate on fatigue life saturates at a value between 0.001 and $0.0004 \% / \mathrm{s}$; the actual value may vary with DO and sulfur content.

Fatigue life can also be affected by loading wave form. Sawtooth or triangular wave forms were used in the ANL and Japanese studies. Fatigue tests are in progress with a trapezoidal wave form that consists of hold periods at peak tensile or compressive strains to 
establish the effects of wave shape. The results will be critical in determining how data obtained from simple laboratory loading histories should be applied to more complex loading situations in operating plants.

\subsubsection{Strain Range}

Fat'gue data in oxygenated water show a distinct threshold strain range value for environmental effects. This threshold for ANL heats of carbon and low-alloy steels appears to be at 0.36\%; fatigue tests on A 106-Gr B and A533-Gr B steels at $=0.36 \%$ strain range, $\approx 0.8 \mathrm{ppm}$ DO, and $0.004 \% / \mathrm{s}$ tensile strain rate did not fail even after 65,000 and 83,000 cycles, respectively (Figs. 6 and 7). For the carbon steel, the fatigue $S-N$ curves in air and water cross over at low strain ranges, 1.e. fatigue life in water is longer than that in air. This apparently different fatigue $\mathrm{S}-\mathrm{N}$ behavior is not caused by the water environment but can be attributed to dynamic strain aging of carbon steels. This is observed in Fig. 6 because of the difference in strain rate for the tests in air and water. The $\mathrm{S}-\mathrm{N}$ curve in air is based on tests at a strain rate of $0.4 \% / \mathrm{s}$, whereas the curve in water represents fatigue tests at a slower strain rate of $0.004 \% / \mathrm{s}$. For a specific strain range, fatigue tests in water at a slower strain rate show greater dynamic strain aging, higher cyclic stress, lower plastic strain range, and longer life.

\subsubsection{Crack Nucleation}

The reduction in fatigue life of carbon and low-alloy steels in oxygenated water may be caused by environmental effects on crack propagation and also on rrack nucleation. The fatigue crack growth behavior of these steels in high-temperature oxygenated water and the effects of sulfur content and loading rate are well known.21-28 The dissolution of MnS inclusions changes the water chemistry near the crack tip. making it more aggressive. This causes enhanced crack growth rates because either (a) the dissolved sulfides decrease the repassivation rate, which increases the amount of metal dissolution for a given oxide rupture rate; or (b) the dissolved sulfide poisons the recombination of $H$ atoms liberated by corrosion, whicil enhances 11 uptake by the steel at the crack tip.

Corrosion processes may also enhance crack nucleation. For example, corrosion pits or cavitles produced by dissolution of MnS inclusions can act as sites for nucleation of fatigue cracks.29.30 All specimens tested in air or water contained several secondary cracks, particularly those tested at high strain ranges. A detailed examination of the gage surfaces of the specimens was conducted to investigate the role of high-temperature oxygenated water on fatigue crack nucleation. The presence of surface deposits often impedes the examination. Consequently, the specimens were descaled with an electrolyte of $2 \mathrm{~g}$ hexamethylene tetramine in $1000 \mathrm{cn}^{3}$ of $1 \mathrm{~N} \mathrm{HCl}$. Typical morphology and micrographs of fatigue cracks on the gage surfaces of A106-Gr B and A533-Gr B specimens tested in air, simulated PWR, and high-DO water, are shown in Figs. 10-15. The descaled specimens show many detalls that were hidden by the oxide scale and/or deposits. Also, the descaled specimens show many more cracks that are not visible on the oxidized surface.

All specimens tested in water showed surface micropitting. These pits form either by corrosion of the material in oxygenated water or by selective dissolution of MnS or other inclusions. Typical examples of corrosion pits on A106-Gr B and A533-Gr B steel specimens are shown in Fig. 14. The micropits are often associated with cracks, as scen in 
Fig. 16: however, these are surtiae cracks in the oxide seale that do not extend inte the material. None of the examined sperimens showed any evidenere that fatigue rateks nucleate preferentally at the microplts. Typieal secondary latigue cracks on descaled surfaces of A06-Gir B and A533-Gir 13 specimens are shown in Fige. 17. Severall corrosion pils and cavities created by dissolution of inclusions are visible on the surface and seem to be associated with the crack. However, there is no indication that the erack actually nucleated at any of these sites. The cracks appear to encounter and pass through these corrosion pits or through stringers of inclusions. Examination of the hatigue specimens indicates that irrespective of environment, cracks in carbon and low-alloy steels nucleate along slip bands, carbide particles, or at the ferrite/pearlite phase boundaries. Examples of such cracks in a carbon steel specimen are shown in Fig. 18.

The metallographic examination was complemented by measuring the cracking frequency for fatigue specimens tested in different enviromments. Figure 19 shows plots of the number of cracks along longitudinal sections of the gage length of AlO6-Gr B and A533-Gr B specimens as a function of strain range in air, simulated PWR, and high-DO water at two different strain rates. In all cases, the number of cracks represent the average value along a $7 \mathrm{~mm}$ gage length. The results show that with the exception of the low-alloy steel tested in simulated PWR water, environment has no effect on the frequency (number/gage length) of cracks. For similar loading conditions, the number of cracks in the specimens tested in air and water with $0.8 \mathrm{ppm} D O$ are identical, although fatigue life is lower by a factor of $\approx 8$ in water. If the reduction in life is caused by enhanced crack nucleation, the specimens tested in high-DO water should show more cracks.

The low-alloy steel specimens tested in either simulated PWR water or deionized water with $<10 \mathrm{ppb}$ DO show a significantly higher frequency of cracks, although their fatigue life is only marginally lower than that in air. These cracks most likely are caused by hydrogen produced by the corrosion reaction. The frequency of cracks is higher only in the low-alloy steel and not in carbon steel because of structural differences; the low-alloy steel has a high tensile strength and a tempered bainitic structure.

The contributions of environment to crack nucleation were further evaluated by conducting exploratory tests. Figure 20 shows the fatigue life of AlO6-Gr $\mathrm{B}$ steel in air (dashed line) and in high-DO water at strain rates of 0.4 and $0.004 \% / \mathrm{s}$ (circle and diamond symbols, respectively). A fatigue specimen was preexposed in water with $0.6 \mathrm{ppm}$ DO for $100 \mathrm{~h}$ at $288^{\circ} \mathrm{C}$ and then tested in air at a total strain range of $0.4 \%$. At this strain range, nearly one-half of the fatigue life may be spent in crack nucleation. Fatigue life should be reduced if surface micropits facilitate crack nucleation: life of this specimen is identical to that of an nonoxidized sperimen. Similar behavior was observed for a preoxidized A533Gr B specimen tested at a strain range of $0.5 \%$. It is possible that a high DO and slow strain rate are also needed to influence crack nucleation. This possibility was checked by first testing a specimen in high-DO water at a strain range of $0.4 \%$ and a strain rate of $0.004 \% / \mathrm{s}$ for 570 cycles $(\approx 25 \%$ of the life at these loading conditions) and then testing in either air or water environment at a strain rate of $0.4 \% / \mathrm{s}$. Fatigue life of these tests should be reduced if crack nucleation contributes in any way to environmental effects. Once again, no reduction in life is observed. These results suggest that the reduction in fatigue life in oxygenated water is primarily due to environmental effects on fatigue crack propagation; t.e., environment has little or no effect on crack nucleation. 


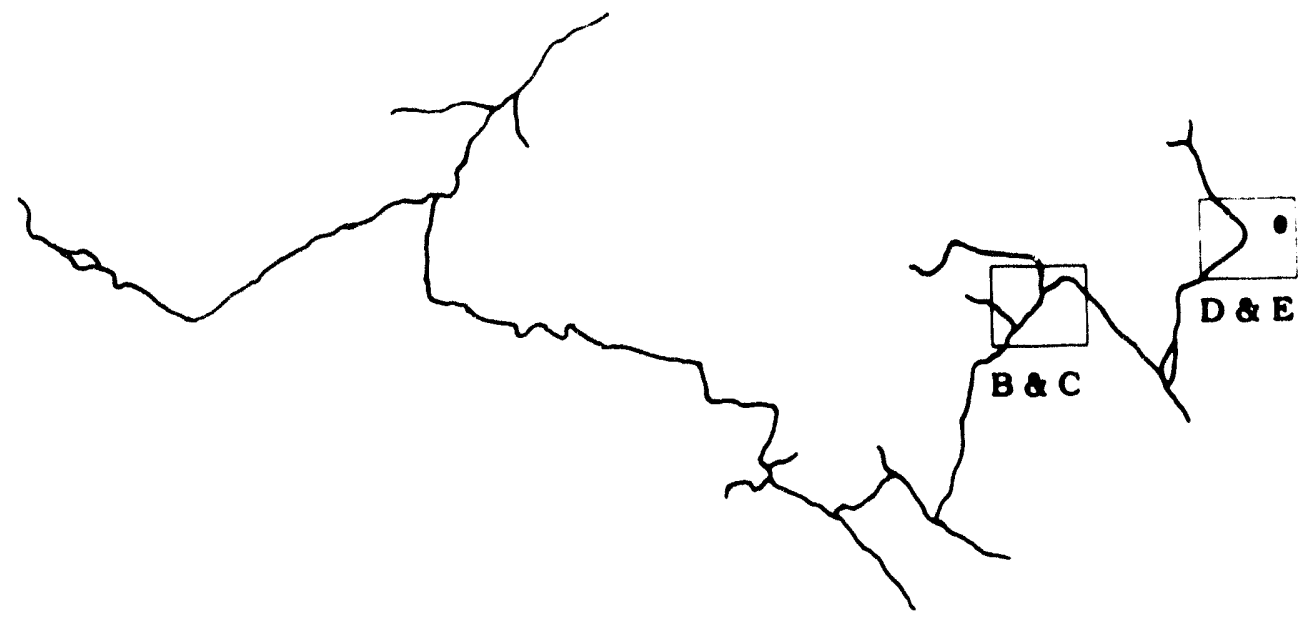

$\stackrel{60 \mu \mathrm{m}}{\longmapsto}$

A

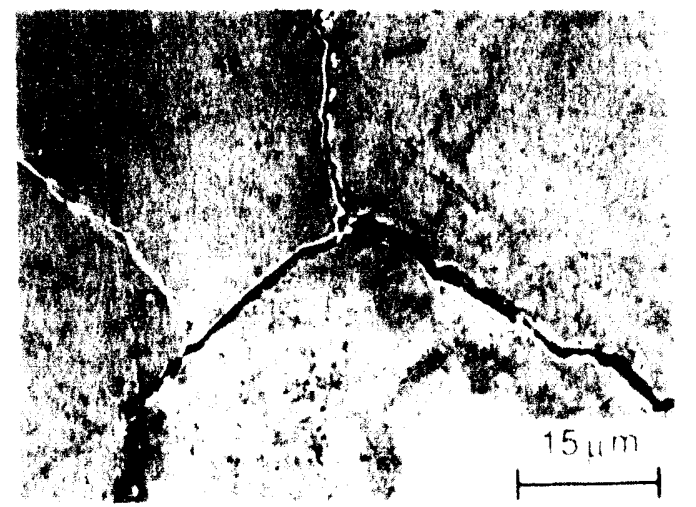

B

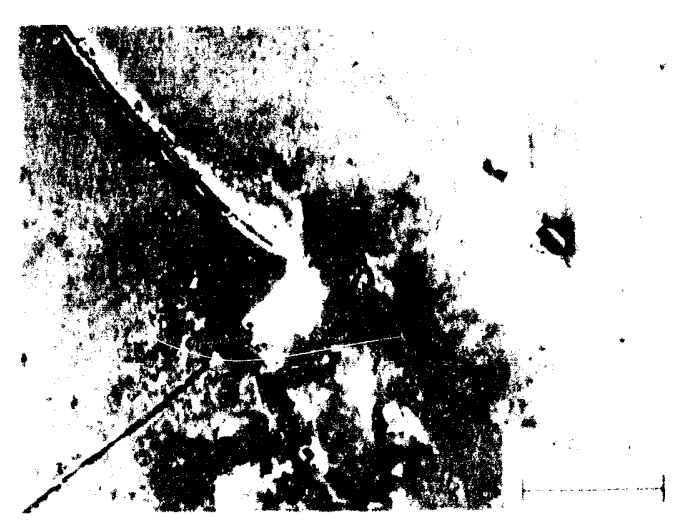

D

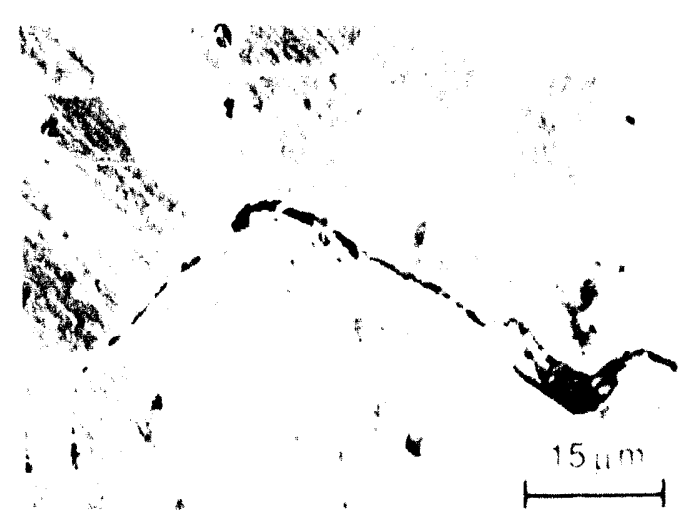

C

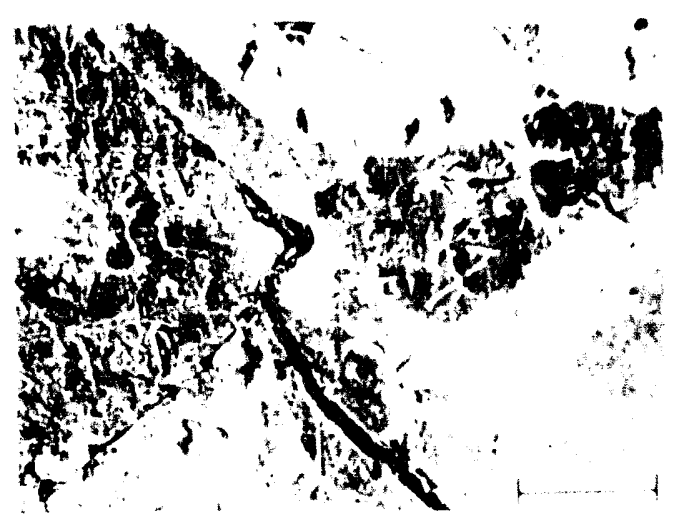

E

Figure 10. Morphology (A) and micrographs of fatigue cracks before ( $B$ and $D)$ and after (C and E) descaling of gage surface of A106-Gr B specimen tested in air 


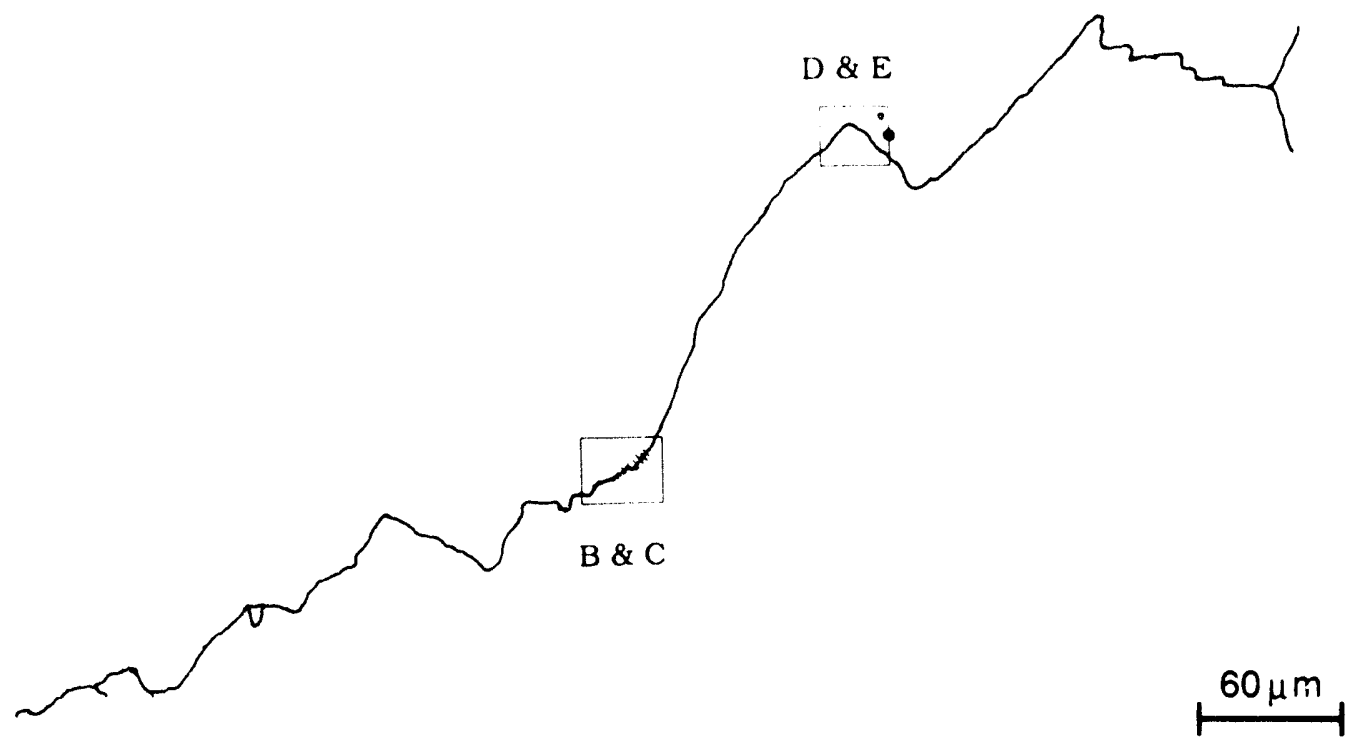

A

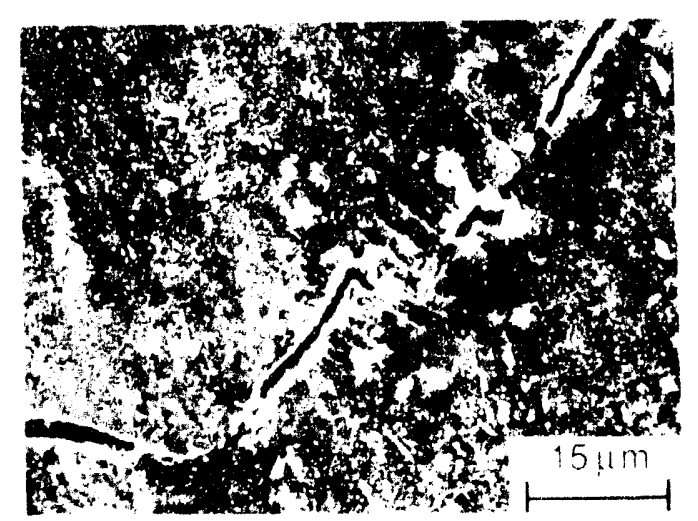

B

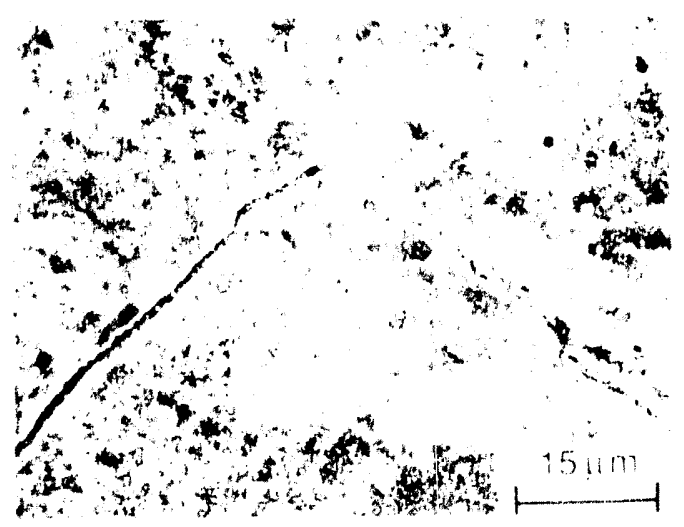

D

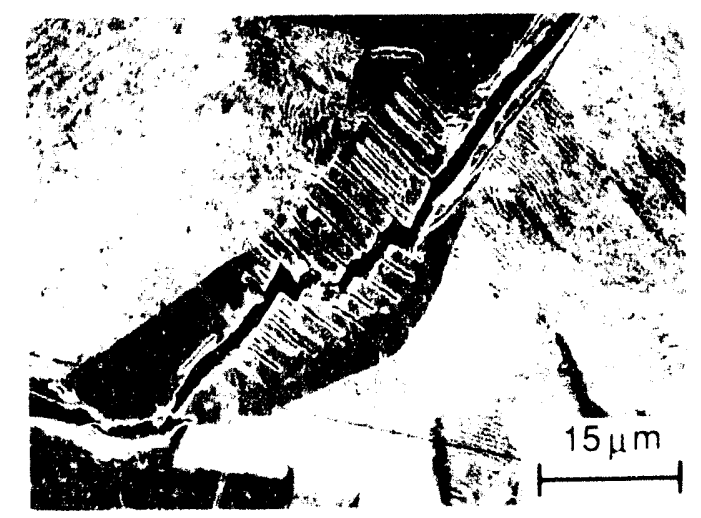

C

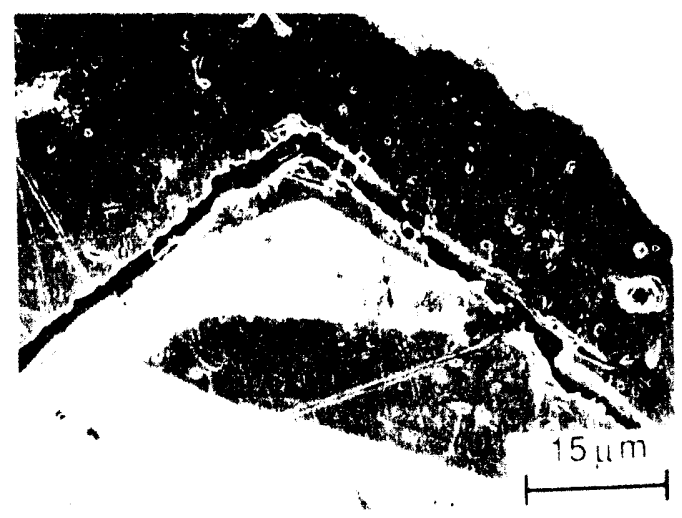

E

Figure 11. Morphology (A) and micrographs of fatigue cracks before ( $B$ and $D$ ) and after (C and $E$ ) descaling of gage surface of A106-Gr B specimen tested in simulated ?WR water 


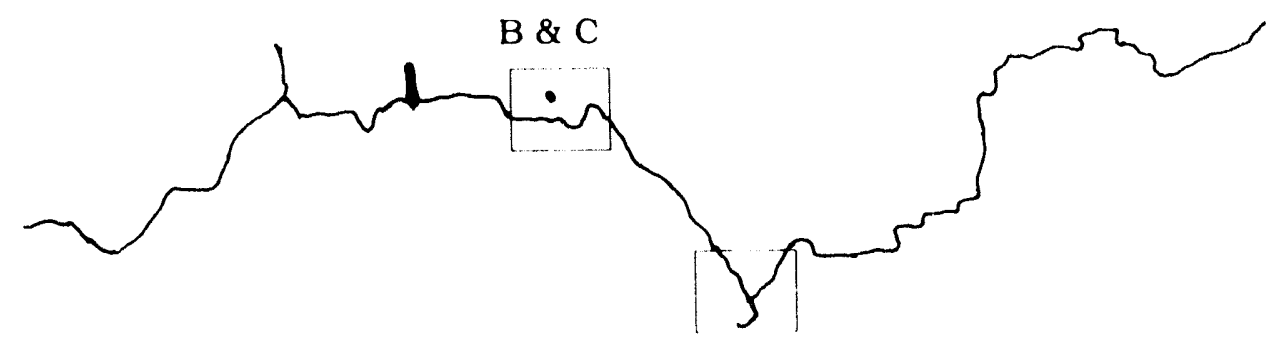

D \& E

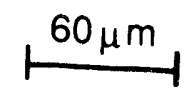

A

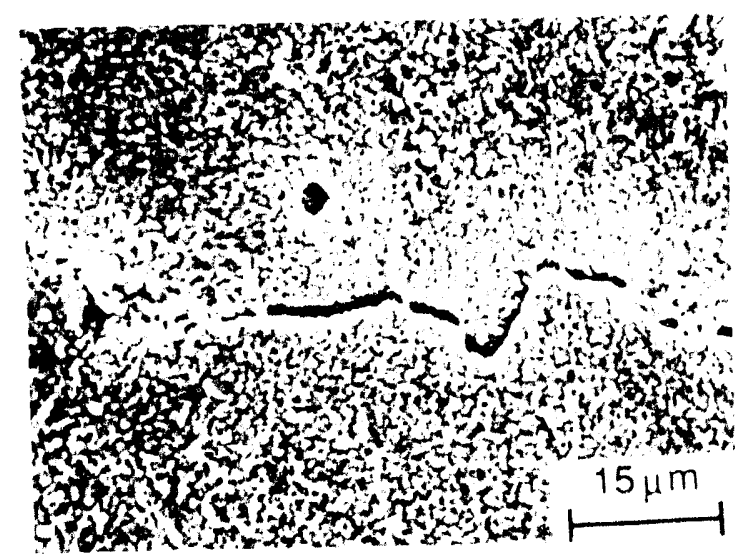

B

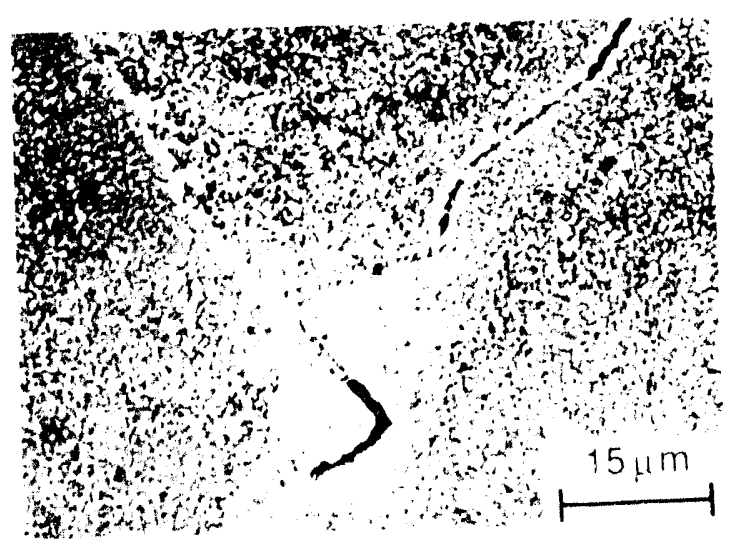

D

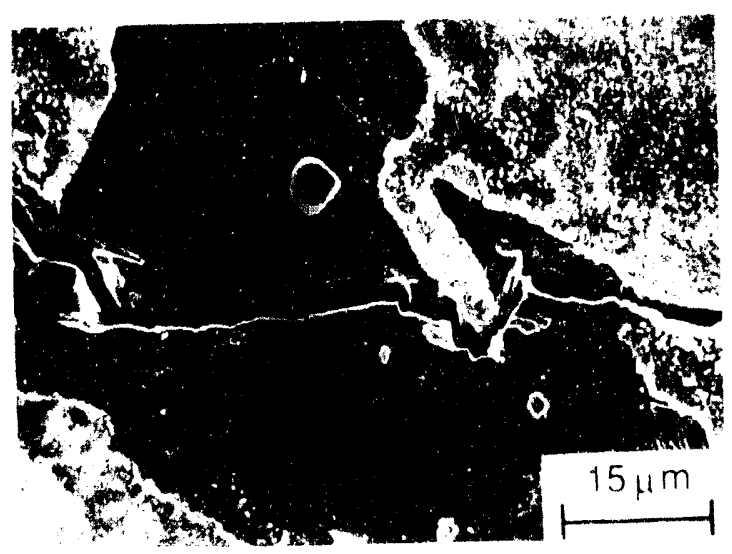

C

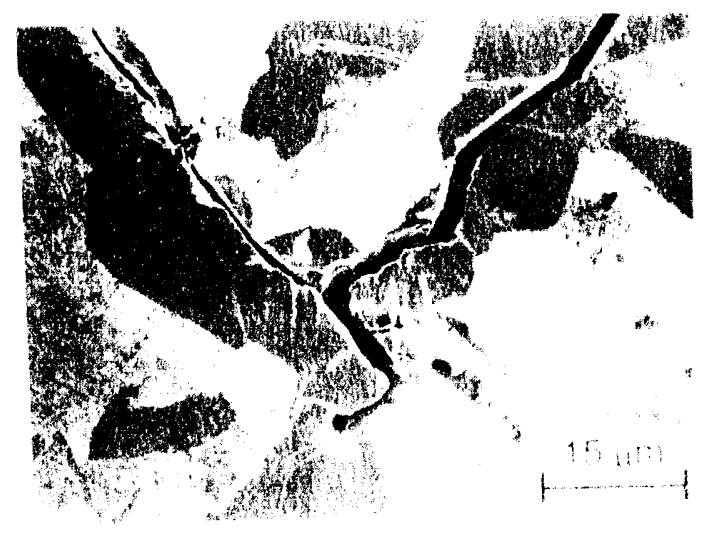

E

Figure 12. Morphology (A) and micrographs of fatigue cracks before (B and D) and after (C and E) descaling of gage surface of A106-Gr B specimen tested in water containing $\approx 0.8 \mathrm{ppm} \mathrm{DO}$ 


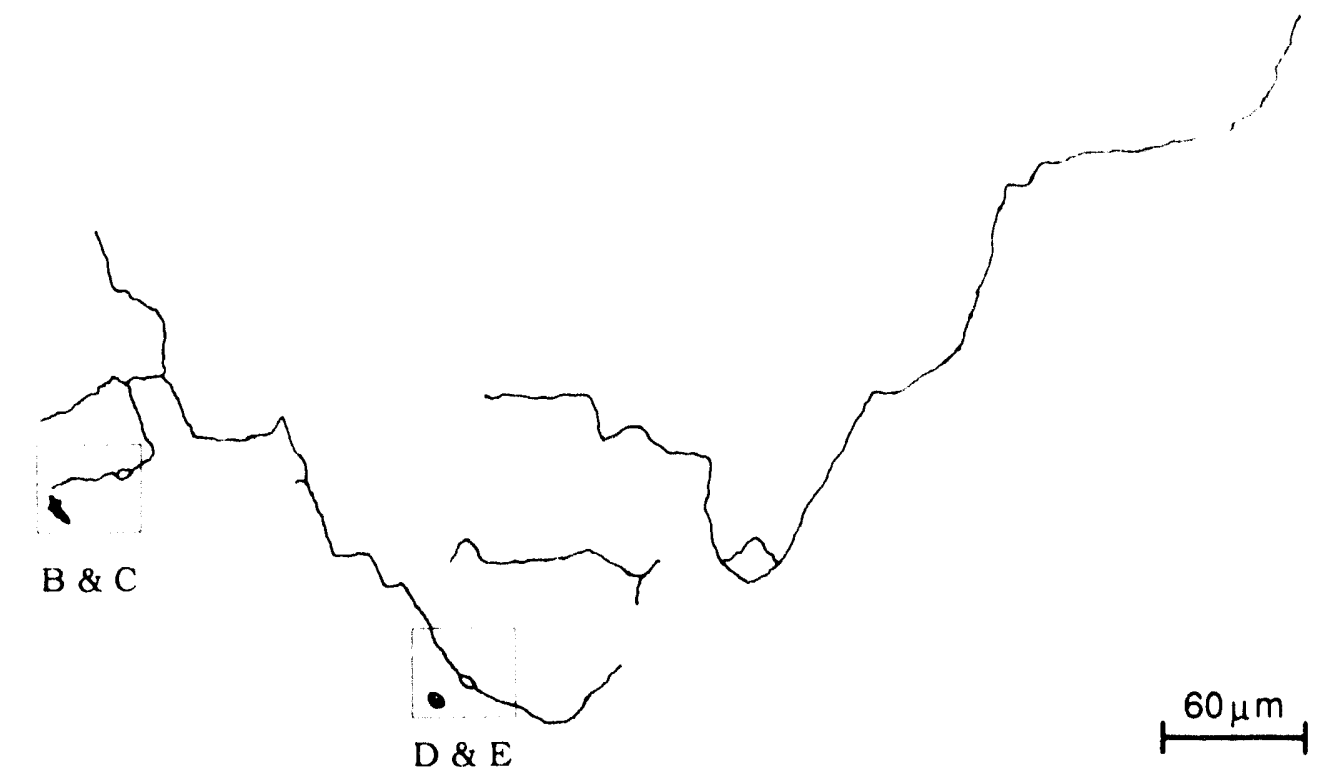

A

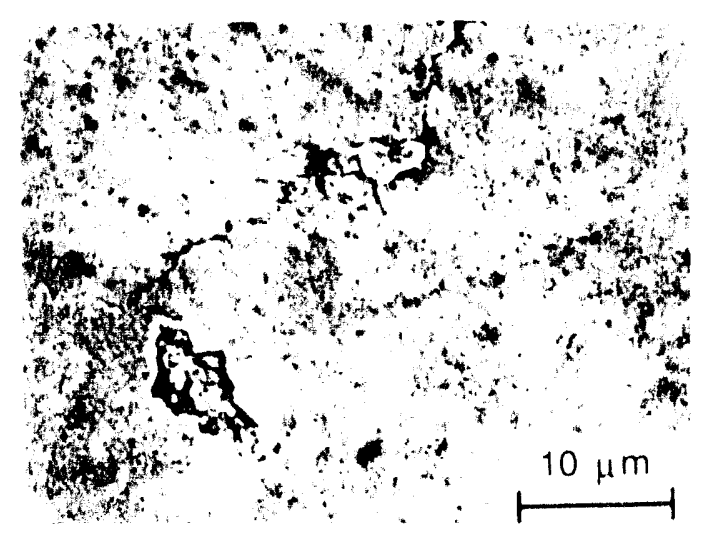

B

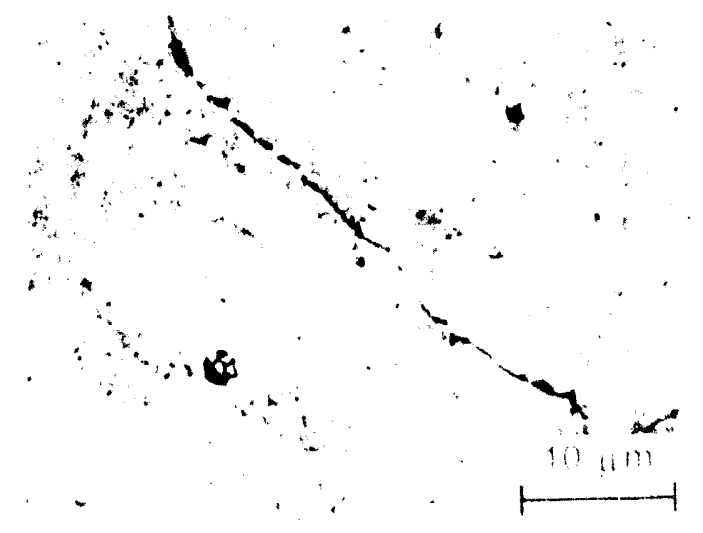

D

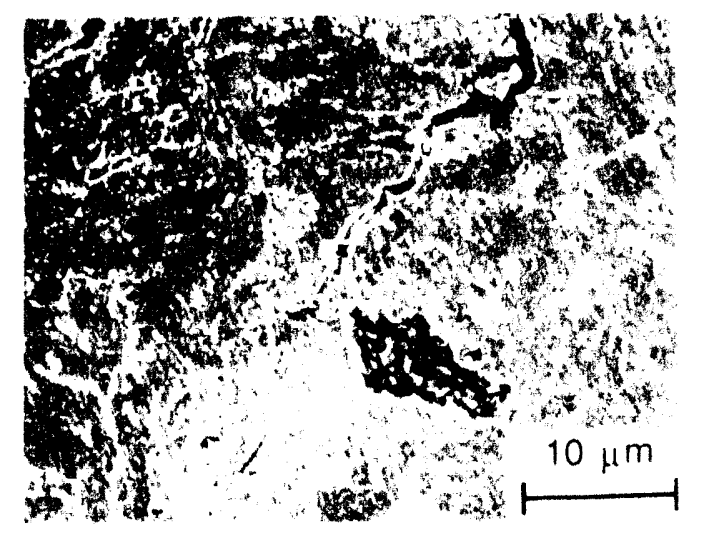

C

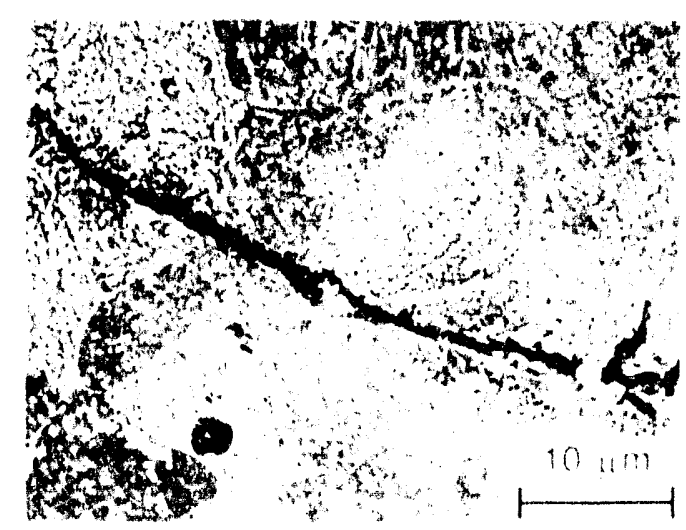

E

Figure 13. Morphology (A) and micrographs of fatigue cracks before (B and D) and after ( $C$ and $E$ ) descaling of gage surface of A533-Gr B specimen tested in air 


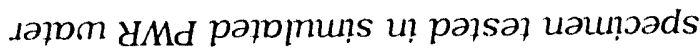

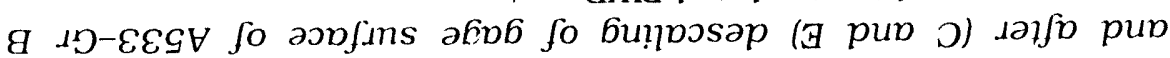

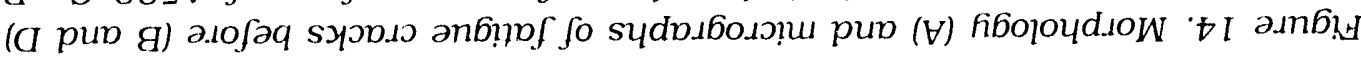

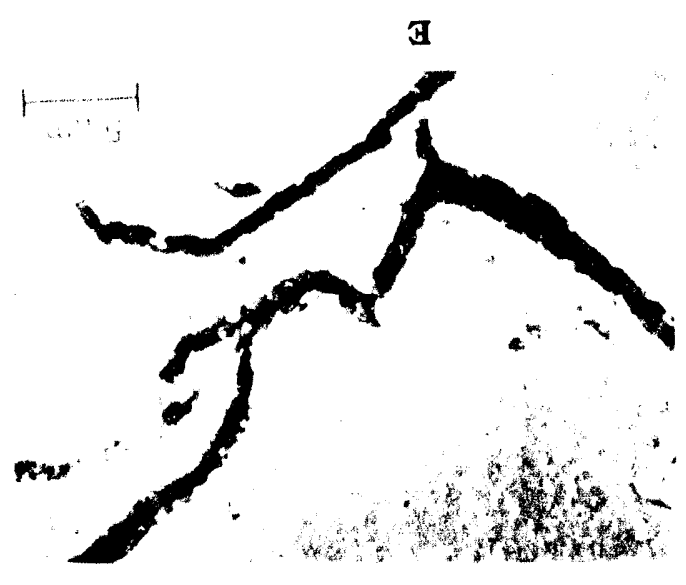

ว

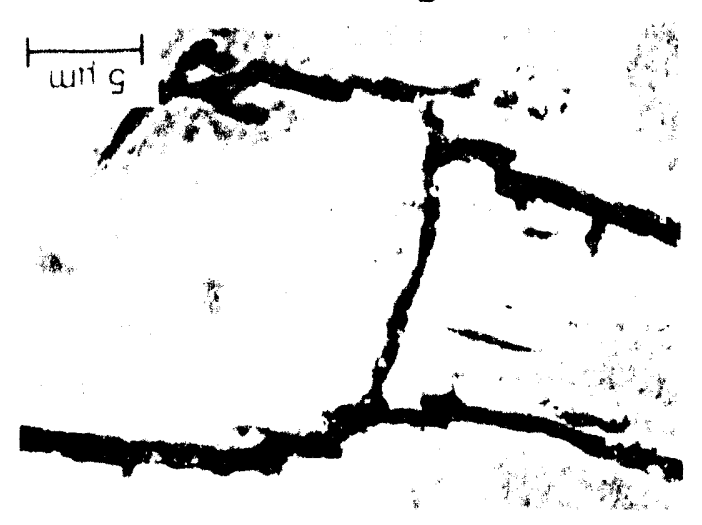

a

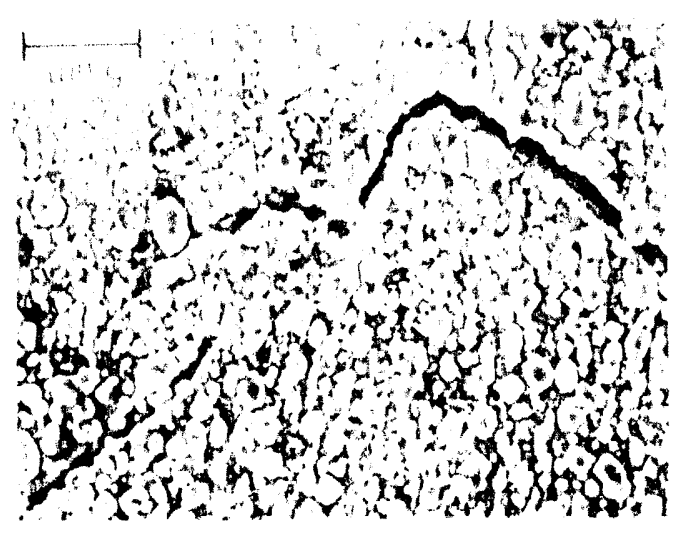

$\mathbf{g}$

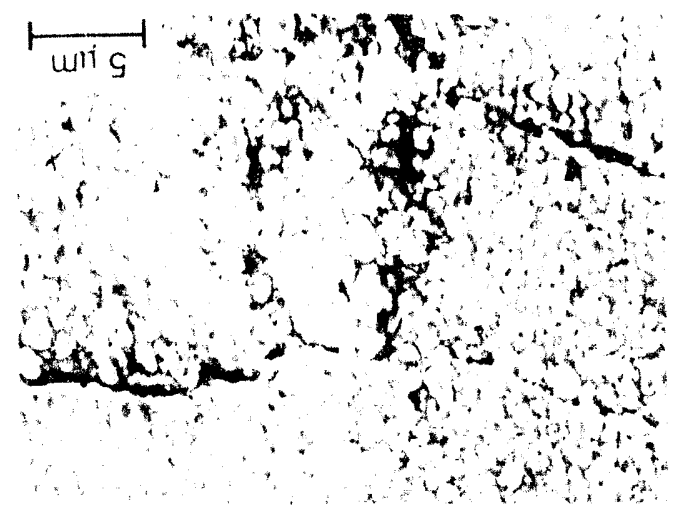

v
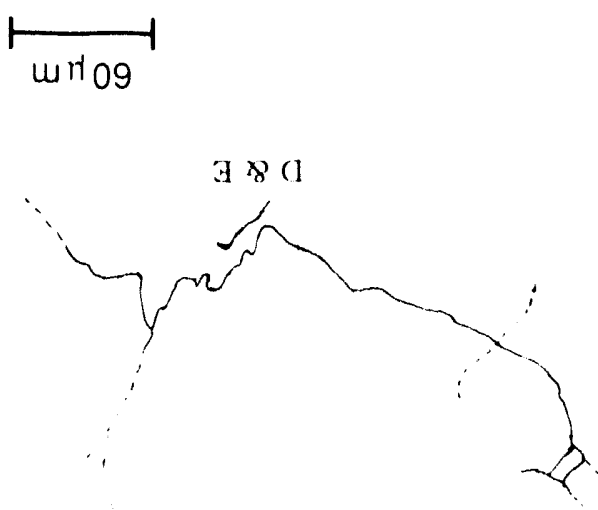

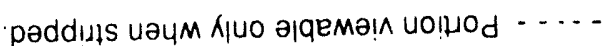

) $8 \mathrm{G}$ 
OCl udd 8.0 Gunu!̣pluos salpm un palsal uauṇads

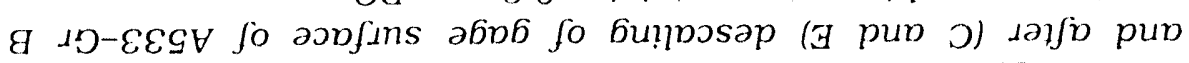

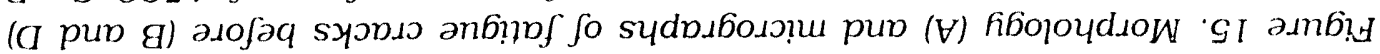
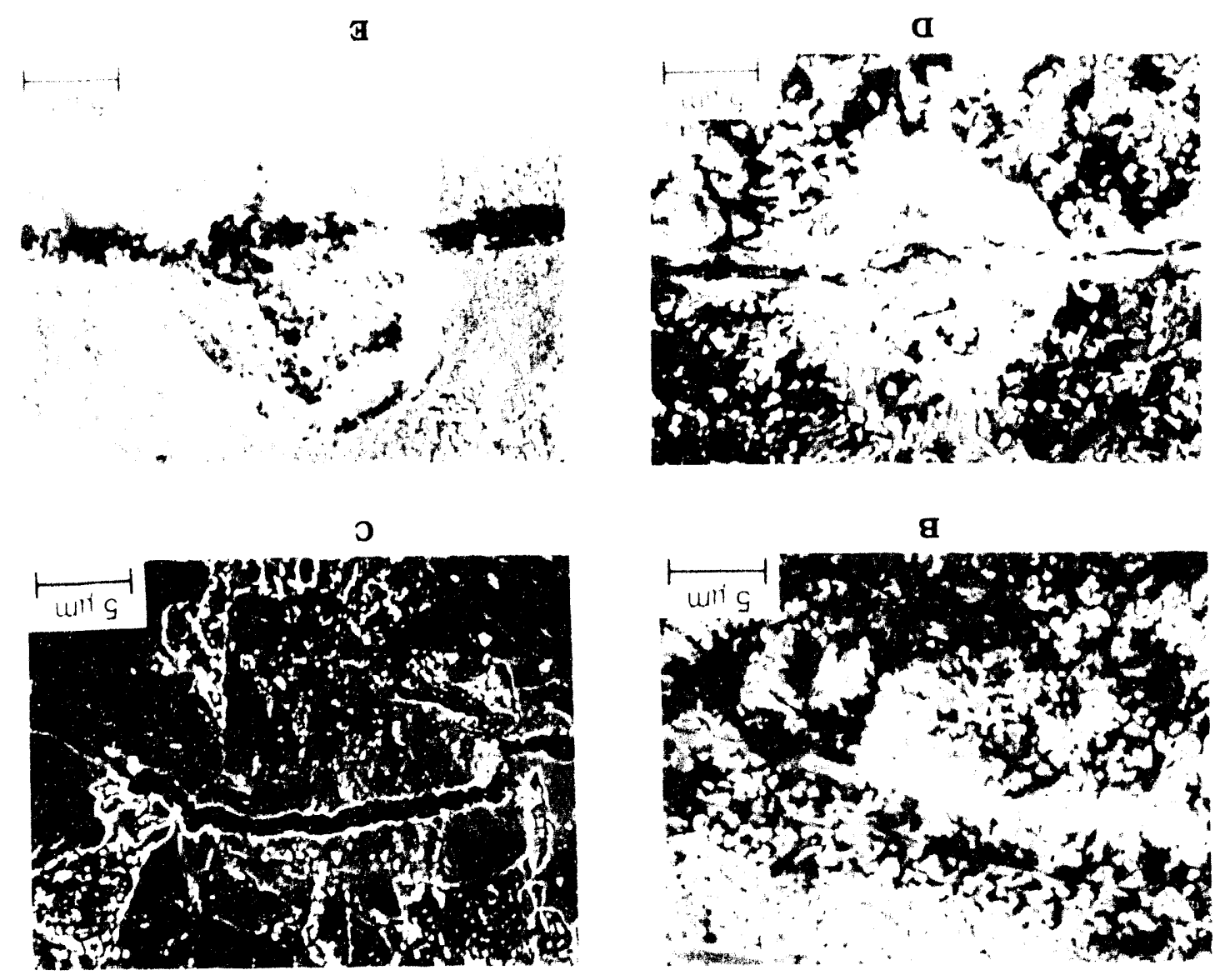

$\mathbf{v}$

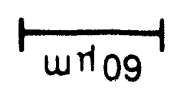

380

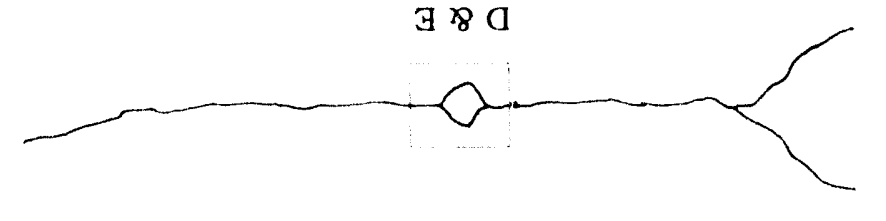

$\supset 89$

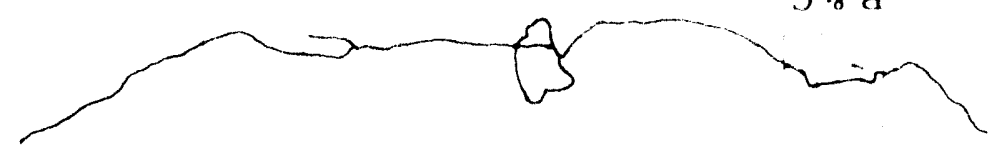




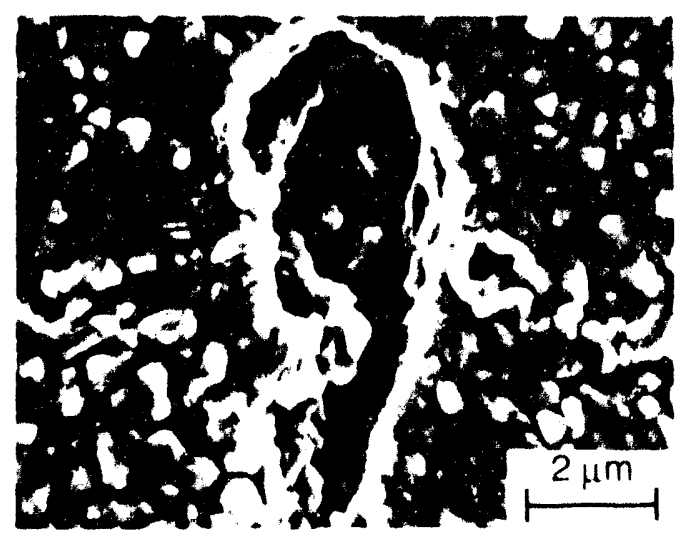

A

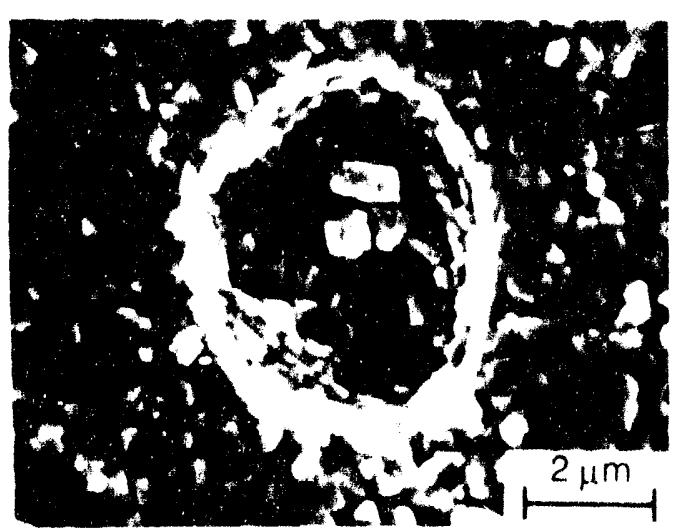

B

Figure 16. Micropits on surface of (A) A106-Gr B carbon steel and (B) A533$\mathrm{Gr} B$ low-alloy steel tested in oxygenated water at $288^{\circ} \mathrm{C}$

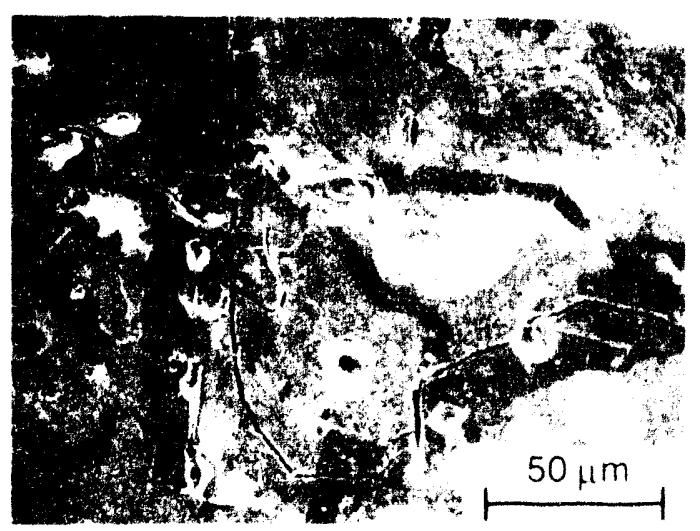

A

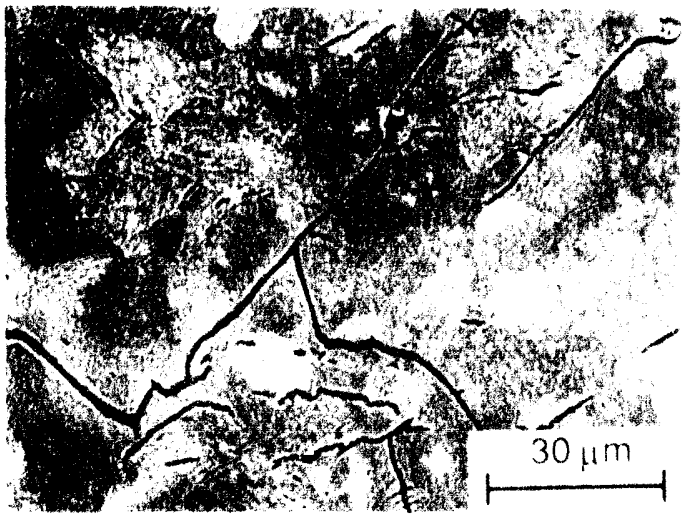

B

Figure 17. Secondary fatigue cracks on descaled surface of (A) A106-Gr B carbon steel and (B) A533-Gr B low-alloy steel specimens
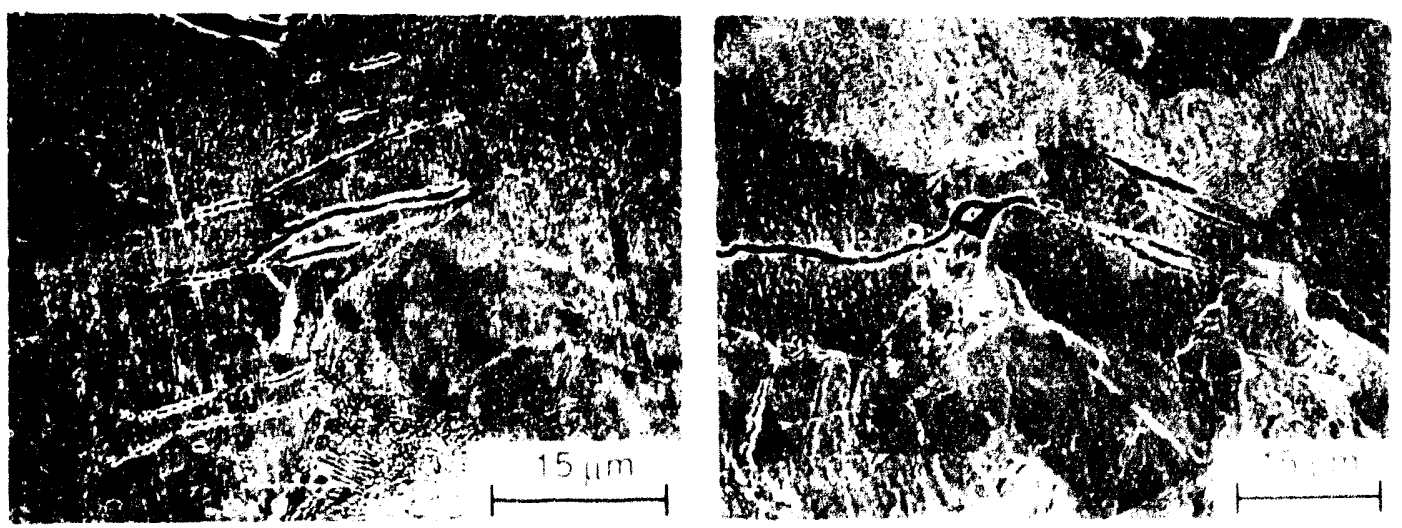

Figure 18. Nucleation of cracks along slip bands, carbide particles, and ferrite/pearlite phase boundaries of curbon steel fatigue specimen 

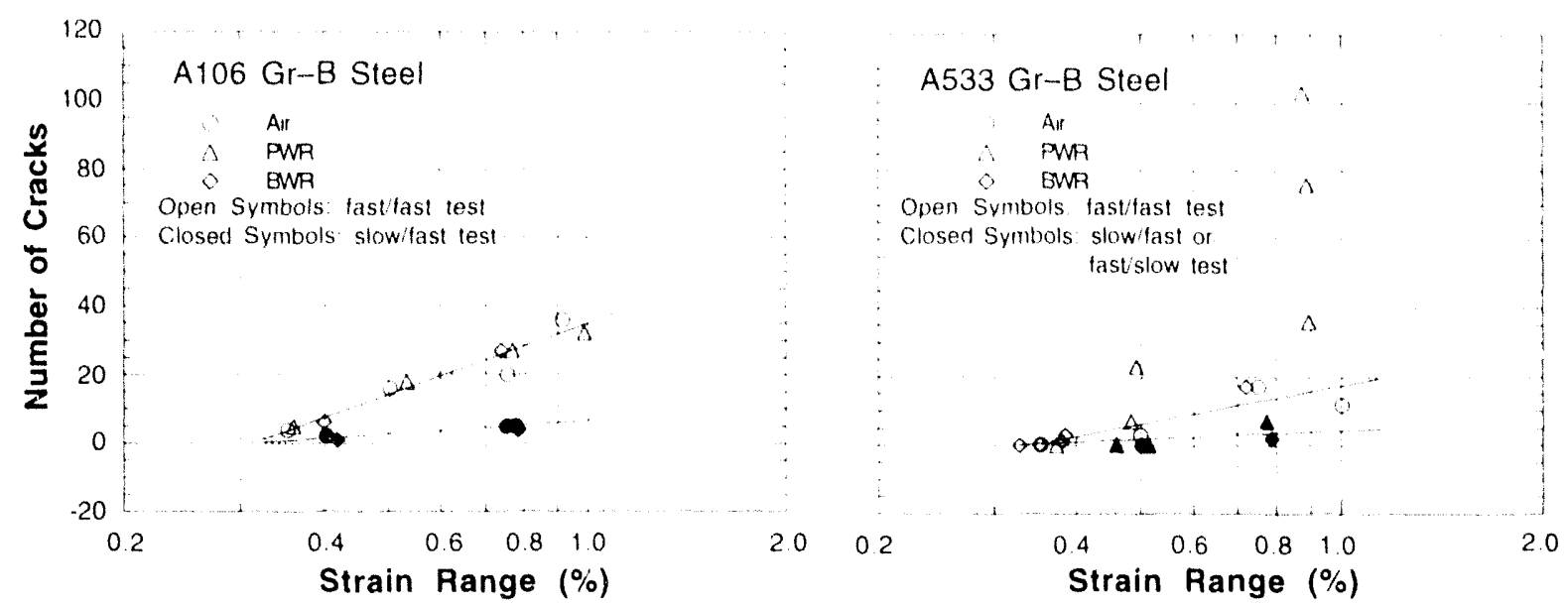

Figure 19. Number of cracks along longitudinal section of fatigue specimens tested in different environments

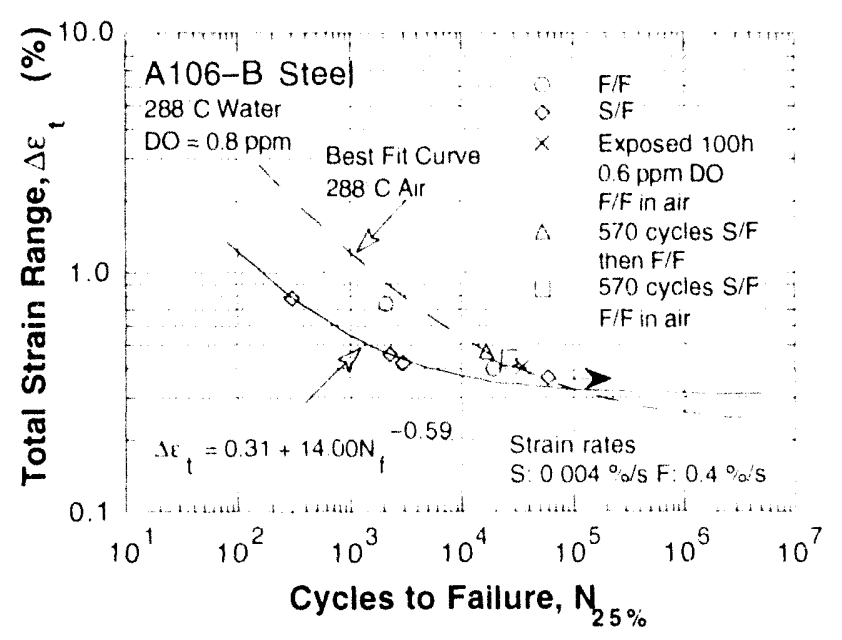

Figure 20.

Environmental effects on nucleation of fatigue cracks

\section{Environmentally Assisted Cracking of Cast SSs in Simulated BWR Water}

Cast-duplex SSs are used extensively in the nuclear industry in pump casings, valve bodies, piping, and other components in coolant systems of LWRs. The steels correspond to ASTM Specification A-35 I grades $\mathrm{CF}-3, \mathrm{CF}-3 \mathrm{~A}, \mathrm{CF}-8, \mathrm{CF}-8 \mathrm{~A}$, and $\mathrm{CF}-8 \mathrm{M}$, where the compositions of $\mathrm{CF}-3 \mathrm{~A}$ and $\mathrm{CF}-8 \mathrm{~A}$ fall within the composition limits of $\mathrm{CF}-3$ and $\mathrm{CF}-8$, but are further restricted to obtain ferrite/austenite ratios that result in higher ultimate and yield strengths. The molybdenum-free $\mathrm{CF}-3$ and $\mathrm{CF}-8$ grades contain low- and highcarbon concentrations $(<0.03$ and $<0.08 \mathrm{wt} . \%$, respectively) and are similar in composition to wrought Types $304 \mathrm{~L}$ and $304 \mathrm{SS}$. The Mo-containing $\mathrm{CF}-3 \mathrm{M}$ and $\mathrm{CF}-8 \mathrm{M}$ grades with low- and high-C content are similar to Types $316 \mathrm{~L}$ and $316 \mathrm{SS}$, respectively. After many years of service at reactor operating temperatures, these steels can undergo thermal aging embrittlement that is caused by precipitation and growth of a $\mathrm{Cr}-\mathrm{rich} \alpha^{\prime}$ phase, an $\mathrm{Ni}-$ and $\mathrm{Si}$-rich $\mathrm{G}$ phase, $\mathrm{M}_{23} \mathrm{C}_{6}, \gamma$ (austenite) in the ferrite, and additional precipitation and/or growth of existing carbides at the ferrite/austenite phase boundaries.31-40 These compositional changes increase the tensile strength ${ }^{41}$ and decrease the impact energy and fracture toughness of the steels. ${ }^{42-52}$ in general, the low-C CF-3 grade is most resistant and the Mo-bearing high-C $\mathrm{CF}-8 \mathrm{M}$ grade is least resistant to thermal embrittlement. ${ }^{42,45}$ 
Cracking of cast SS components exposed to I,WR cocolants is mother infrequent compared to that of other materials. However, an inspeetion of the drywell of a BWR to determine the cause of an increase in undentified leakage revealed a through-wall ratak in the manual gate valve in the condensate return line of the cmergency condenser system." Subsequently, the internal components of other valves in the emergency rondenser system were removed and insperted by visual, radiographic, and ultasonic tests. Inspections of the inner surface of the valves revealed racks near drain holes in the valve bodies, which were made from CF-8M SS. Some of the racks were within 0.15\%0.35 in. of passing through the $1.25-$ in. wall thickness $(-70-90 \%$ through wall). A metallographic examination of a boat specimen revealed that the material contained $=15^{\circ} \%$ delta ferrite and that the crack propagated transgramularly with little secondary cracking. which is characteristic of a fatigue crack.

The purpose of the present work is to (a) determine whether local compositional changes and concomitant increases in strength of the materials caused by thermal aging can influence EAC under cyclic loading in high-temperature water, and (b) establish whether CGR curves for wrought SS in high-temperature oxygenated water are applicable to cast grades of the steel in the as-received and thermally aged conditions.

\subsection{Technical Progress (W. E. Ruther and T. F. Kassner)}

During this reporting period, fracture-mechanics CGR tests were completed on two 1T-compact tension (CT) specimens of CF-8M (Heat 75) in the as-received and thermally aged $\left(30,000 \mathrm{~h}\right.$ at $\left.350^{\circ} \mathrm{C}\right)$ conditions in air at $289^{\circ} \mathrm{C}$. These tests provide baseline data to assess the influence of high-temperature water on crack growth in the material. Additional tests were performed on 1TCT specimens of $\mathrm{CF}-8$ SS (Heat 68) in the as-received and thermally aged $\left(30,000 \mathrm{~h}\right.$ at $\left.350^{\circ} \mathrm{C}\right)$ conditions to determine the influence of $\mathrm{DO}$ in highpurity (HP) water on the CGRs. Results obtained on as-received CF-8M (Heat 75) and specimens of CF-8M (Heat 75) and $\mathrm{CF}-8$ (Heat 68) steel aged for $10.000 \mathrm{~h}$ at $400^{\circ} \mathrm{C}$ and 30,000 at $350^{\circ} \mathrm{C}$ were presented in previous reports. 53.54

The aging conditions for these heats of steel were sufficient to reach a "saturation" Charpy-impact energy $\mathrm{C}_{V \text { sat, }}$ i.e., a minimum value that would be achieved by the materials after very-long-term aging. The actual value of the saturation impact energy for a specific cast SS is independent of aging temperature but depends strongly on the composition of the steel. It is lower for the Mo-bearing $\mathrm{CF}-3 \mathrm{M}$ and $\mathrm{CF}-8 \mathrm{M}$ steels than for the Mo-free $\mathrm{CF}-3$ and $\mathrm{CF}-8$ steels, and decreases with an increase in ferrite content or the $\mathrm{C}$ or $\mathrm{N}$ concentration in the steels. The room-temperature $\mathrm{C}_{V \text { sat }}$ values for cast SSs in thermal aging embrittlement studies conducted at $A N L 50$ ranged from $\approx 30$ to $162 \mathrm{~J} \cdot \mathrm{cm}^{-2}$. The room-temperature impact energy values for Heats No. $75(\mathrm{CF}-8 \mathrm{M})$ and $68(\mathrm{CF}-8)$ aged for $30,000 \mathrm{~h}$ at $350^{\circ} \mathrm{C}$ were 30 and $65 \mathrm{~J} \cdot \mathrm{cm}^{-2}$, respectively, which are indicative of materials with low fracture toughness after thermal aging. The chemical composition and ferrite content of these steels, and of $\mathrm{CF}-3$ and $-3 \mathrm{M}$ grades tested previously, 55,56 are given in Table 5 .

* NRC Information Notice 92-50: "Cracking of Valves in the Condensate Return Lines of a BWR Emergency Condenser System." July 2, 1992. 
Table 5. Chemical composition and ferrite content of cast SSs for corrosion fatigue tests in simulated BWR water

\begin{tabular}{|c|c|c|c|c|c|c|c|c|c|c|c|c|}
\hline \multirow[t]{2}{*}{ Material } & \multirow{2}{*}{$\begin{array}{l}\text { Heat } \\
\text { No. }\end{array}$} & \multicolumn{9}{|c|}{ Composition (wt."1) } & \multicolumn{2}{|c|}{ Ferrite $(\%)$} \\
\hline & & $\mathrm{Cr}$ & Mo & $\mathrm{Ni}$ & $M n$ & $\mathrm{Si}$ & ( & $\mathrm{N}$ & $\mathrm{P}$ & $\mathrm{S}$ & Calc. & Meas \\
\hline $\mathrm{CF}-8$ & 68 & 20.64 & 0.31 & 8.08 & 0.64 & 1.07 & 0.06 .3 & 0.062 & 0.021 & 0.014 & 14.9 & 23.4 \\
\hline $\mathrm{CF}-8 \mathrm{M}$ & 75 & 20.86 & 2,58 & 9.12 & 0.53 & 0.67 & 0.065 & 0.052 & 0.022 & 0.012 & 24.8 & 27.8 \\
\hline $\mathrm{CF}-3$ & $\mathrm{P} 2$ & 20.20 & 0.16 & 9.38 & 0.74 & 0.94 & 0.019 & 0.062 & 0.019 & 0.006 & 12.5 & 15.6 \\
\hline$C F-3 M$ & F5524 & 19.38 & 2.38 & 11.80 & 0.96 & 1.35 & 0.018 & 0.099 & 0.015 & 0.005 & 5.9 & 5.0 \\
\hline
\end{tabular}

CGRs in air of the as-received and aged $\left(30,000 \mathrm{~h}\right.$ at $\left.350^{\circ} \mathrm{C}\right) \mathrm{CF}-8 \mathrm{M}$ specimens are shown in Table 6. The tests were conducted at load ratios between 0.2 and 0.9 with a positive sawtooth wave form at a frequency of $7.7 \times 10^{-2} \mathrm{~Hz}$ and a rise time of $12 \mathrm{~s}$. Figure 21 shows a plot of the experimental results versus calculated values for wrought SS in air from Section XI of the ASME Code under the same loading conditions. The experimental results for the steel in both the as-received and aged conditions are consistent with predicted values for wrought SSs in alr at CGRs $>5 \times 10^{-10} \mathrm{~m} \cdot \mathrm{s}^{-1}$. At lower rates, the experimental values are lower by one order of magnitude. It is evident that thermal aging has no effect on the CGRs of $\mathrm{CF}-8 \mathrm{M}$ SS in air.

Figure 22 shows the fracture surface. fracture surface morphology, and crack path in the as-received specimen. The fracture surface and fracture surface morphology of the thermally aged specimen are shown in Fig. 23. Faint striations are visible on the fracture surface of the thermally aged specimen in Fig. 23, whereas this is less evident in the asreceived specimen. The crack path in the latter specimen was predominantly transgranular in relation to the austenite grains. It was not possible to obtain a photomicrograph of the crack path in the thermally aged specimen because the crack opened in the last phase of the test.

Additional CGR tests were conducted on as-received and thermally aged specimens of $\mathrm{CF}-8$ cast SS (Heat 68) in $289^{\circ} \mathrm{C}$ HP water containing $0.06-2.1 \mathrm{ppm}$ DO to supplement previous results in water with $0.4-4.5 \mathrm{ppm}$ DO. To achieve the desired DO concentration in the effluent water in all tests, it is necessary to compensate for consumption of oxygen by corrosion of the autoclave wall and internal components such as the load train, specimens, and internal flow shroud and by oxidation of trace amounts of organic species that can pass through the purification system. To obtain DO concentrations in the effluent water $>0.2 \mathrm{ppm}$, the DO level in the feedwater can be increased by an appropriate amount by adjusting the oxygen concentration in the cover gas of the feedwater tank. Similarly, a very low DO concentration in the effluent water $(<0.01 \mathrm{ppm})$ can be easily achieved by deoxygenated feedwater $(\approx 0.01 \mathrm{ppm} D O)$ because of corrosion of the system. However, it is virtually impossible to control DO concentrations in the effluent water in the range of 0.05$0.2 \mathrm{ppm}$ by adjusting the DO of the feedwater in a low-flow-rate system. Therefore, the test system was modified to attain DO values in this range by periodic injection of an oxygen/nitrogen gas mixture into the feedwater as it entered the autoclave. The frequency of oxygen injection was controlled by a timer that was activated by the output of an electrochemical cell composed of a platinum electrode and an $0.1 \mathrm{M} \mathrm{AgCl} / \mathrm{Ag}$ external 
Table 6. Crack growth results for as-recelved and aged CF-8M cast SS 1T-compacttension specimens $a$ under cyclic loading $b$ in air at $289^{\circ} \mathrm{C}$

\begin{tabular}{|c|c|c|c|c|c|c|c|c|}
\hline \multirow[b]{3}{*}{$\begin{array}{l}\text { Test } \\
\text { No. }\end{array}$} & \multirow[b]{3}{*}{$\begin{array}{c}\text { Time. } \\
\mathrm{h}\end{array}$} & \multirow{3}{*}{$\begin{array}{l}\text { Load } \\
\text { Ratio }\end{array}$} & \multirow[b]{3}{*}{$\begin{array}{l}\text { Freq.. } \\
10^{-2} \mathrm{~Hz}\end{array}$} & \multirow{3}{*}{$\begin{array}{c}\text { Rise } \\
\text { Time, } \\
\text { s }\end{array}$} & \multirow{2}{*}{\multicolumn{2}{|c|}{$\begin{array}{c}\text { CF-8M (No, 743-07B) } \\
\text { As-recelved }\end{array}$}} & \multirow{2}{*}{\multicolumn{2}{|c|}{$\begin{array}{l}\mathrm{CF}-8 \mathrm{M}(\text { No. } 742-05 \mathrm{~B}) \\
\text { Aged }\left(30,000 \mathrm{~h} \oplus 350^{\circ} \mathrm{C}\right)\end{array}$}} \\
\hline & & & & & & & & \\
\hline & & & & & $\begin{array}{c}\mathrm{K}_{\max } \mathrm{c} \\
\mathrm{MPa} \cdot \mathrm{m}{ }^{1 / 2}\end{array}$ & $\begin{array}{l}\text { Rate. } \\
10^{-10} \mathrm{~m} \cdot \mathrm{s}^{-1}\end{array}$ & $\begin{array}{c}\mathrm{K}_{\max } \mathrm{c} \\
\mathrm{MPa} \cdot \mathrm{m}^{1 / 2}\end{array}$ & $\begin{array}{l}\text { Rate. } \\
10^{-10} \mathrm{~m} \cdot \mathrm{s}^{-1}\end{array}$ \\
\hline 1 & $\begin{array}{l}720- \\
748\end{array}$ & 0.7 & 7.7 & 12 & 31.0 & 26.7 & 30.6 & 24.4 \\
\hline 2 & $\begin{array}{l}817- \\
850\end{array}$ & 0.3 & 7.7 & 12 & 31.6 & 59.2 & 31.5 & 64.9 \\
\hline $3 d$ & $\begin{array}{l}870- \\
1160\end{array}$ & 0.9 & 7.7 & 12 & 31.9 & 0.1 & 31.8 & 0.4 \\
\hline $4 d$ & $\begin{array}{l}1165- \\
1121\end{array}$ & 0.9 & 7.7 & 12 & 36.0 & 0.1 & 35.9 & 0.1 \\
\hline 5 & $\begin{array}{l}1835- \\
2040\end{array}$ & 0.8 & 7.7 & 12 & 37.0 & 6.3 & 36.8 & 7.0 \\
\hline 6 & $\begin{array}{l}2162- \\
2865\end{array}$ & 0.9 & 7.7 & 12 & 45.9 & 0.5 & 45.9 & 0.7 \\
\hline 7 & $\begin{array}{l}3002- \\
3044\end{array}$ & 0.7 & 7.7 & 12 & 46.8 & 24.1 & 47.4 & 36.6 \\
\hline $8 e$ & $\begin{array}{l}3050- \\
3056\end{array}$ & 0.2 & 7.7 & 12 & 49.0 & 343.0 & 54.8 & 1040.0 \\
\hline
\end{tabular}

a Heat No. 74 for CF-8M contains $18.4 \%$ ferrite.

bPositive sawtooth wave form was used.

cStress intensity, $\mathrm{K}_{\max }$, values at the end of the time period.

dRate calculated from the maximum change in crack length during the test; other rates, except for Test 8 , were determined from least-squares fit to the data.

e Rate determined from a single measurement of crack extension.

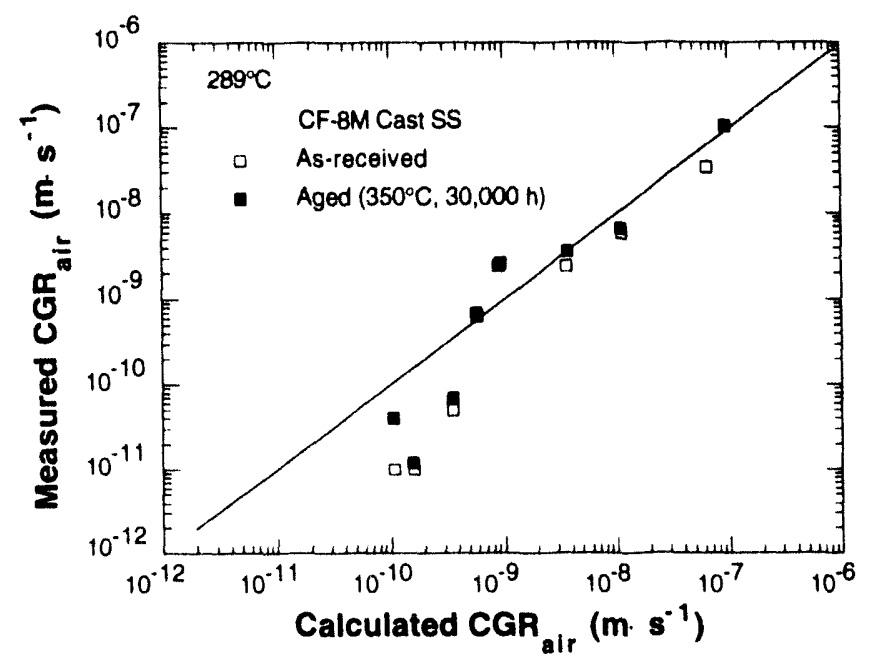

Figure 21.

Measured CGRs of CF-8M SS (Heat 74) in as-received and aged $\left(350^{\circ} \mathrm{C}\right.$ for $30,000 \mathrm{~h}$ ) conditions in air at $289^{\circ} \mathrm{C}$ versus calculated CGRs for wrought SS from Section XI of ASME Code 


\begin{tabular}{|c|c|c|}
\hline $\begin{array}{l}\text { HEAT TREATMENT } \\
\text { As received }\end{array}$ & $\begin{array}{l}\text { LOAD CONIDITIONS } \\
K_{\text {max }}=31+49 \mathrm{MPa}^{1 / 2} \\
\mathrm{R}=0.20 .9 ; \text { Freel }=0.077 \mathrm{~Hz}\end{array}$ & $\begin{array}{l}\text { ENVIRONMENT } \\
\text { laboratory } A \mathrm{ir} \\
\text { 2KY }\end{array}$ \\
\hline
\end{tabular}

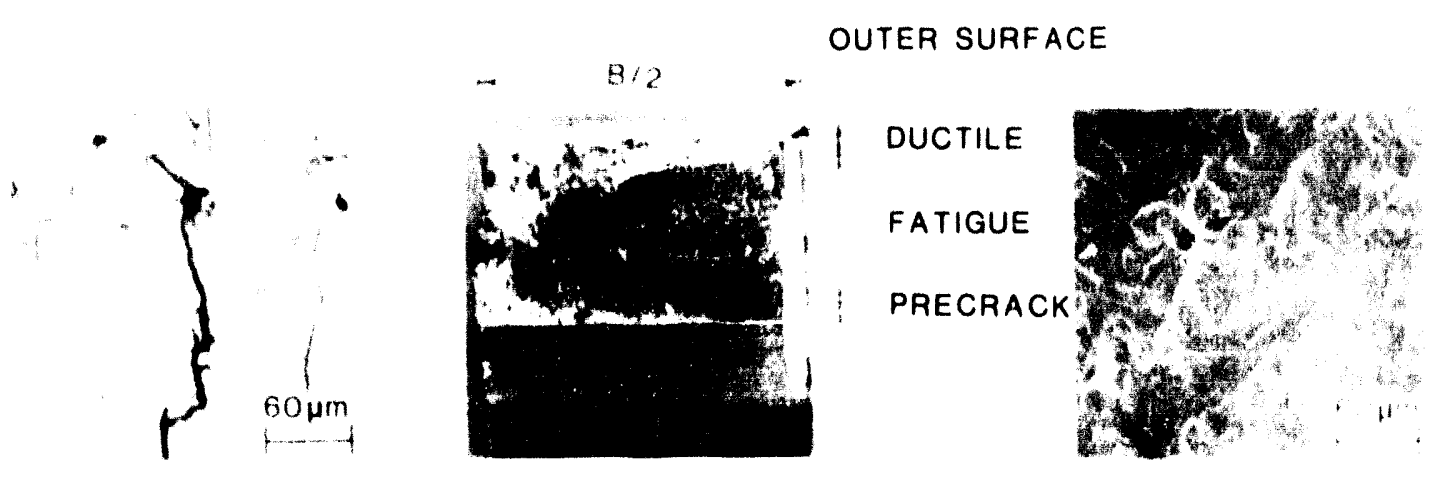

CRACK TIP REGION

FRACTURE SURFACE

FRACTURE MORPHOLOGY

Figure 22. Crack path. fracture surface, and fracture morphology of asreceived 1TCT specimen of CF-8M cast SS (No. 743-07B) after crack growth experiment in air at $289^{\circ} \mathrm{C}$

\begin{tabular}{|c|c|c|}
\hline HEAT TREATMENT & LOAD CONDITIONS & ENVIRONMENT \\
$350^{\circ} \mathrm{C}$ for $30.000 \mathrm{~h}$ & $\mathrm{~K}_{\max }=31-55 \mathrm{MPa} \cdot \mathrm{m}^{1 / 2}$ & Laboratory Air \\
& $\mathrm{R}=0.2-0.9 ;$ Freq $=0.077 \mathrm{~Hz}$ & $289^{\circ} \mathrm{C}$ \\
\hline
\end{tabular}

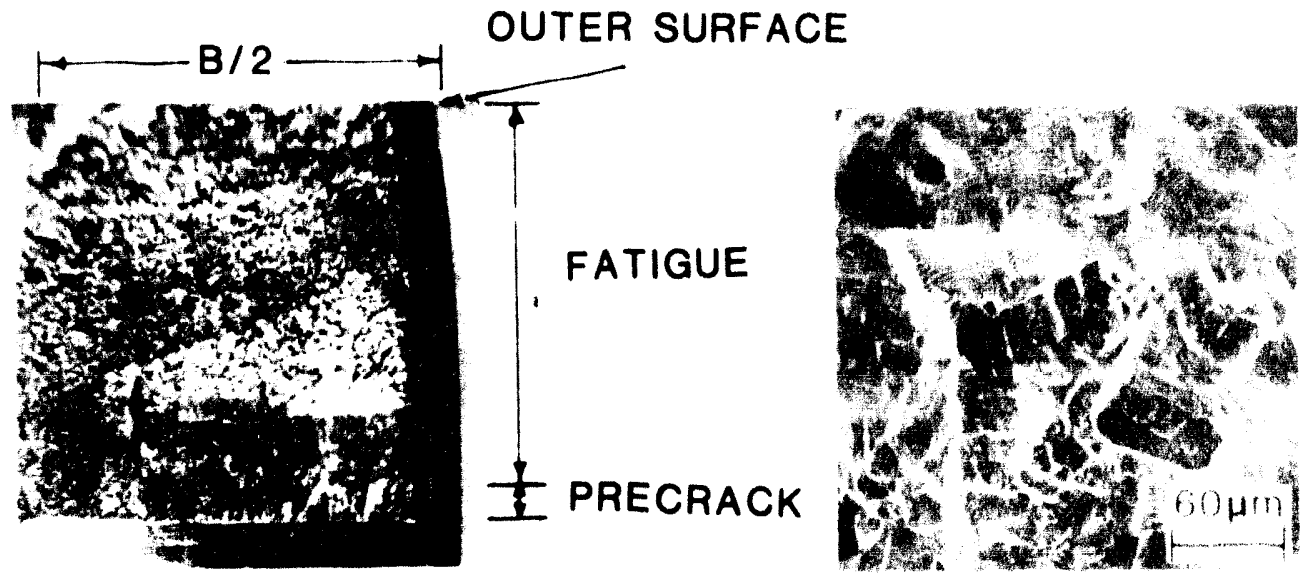

FRACTURE SURFACE

FRACTURE MORPHOLOGY

Figure 23. Fracture surface and fracture morphology of thermally aged 1TCT specimen of CF-8M cast SS (No. 742-O5B) after rrack growth experiment in air at $289^{\circ} \mathrm{C}$ 
reference electrode located at the outlet of the antoclave at $289 \mathrm{c}$. When the electrochemical potential (ECP) decreased below the control value (e.g., -200 mVStIE) by a gtven amoumt (e.g., $10 \mathrm{mV}$ ), a solenotd valve located in the feedwater line opened momentarily and admitted a small volume of oxygen that dissolved in the feedwater as it flowed through a heat exchanger and was heated to $289 \mathrm{C}$ before it entered the autoclave. Based on the operating characteristies of the particular system, namely, the target DO level, flow rate, and temperature, the number of oxygen injection events to attain the desired DO level within $\pm 15 \%$ was determined. This control system was also used to obtain DO concentrations $>0.2 \mathrm{ppm}$ in the effluent water is subsequent tests.

Results of the CGR tests on as-received and thermally aged CF-8 specimens are shown in Table 7 (Tests $9-15$ ) along with previous results ${ }^{54}$ on these specimens and a thermally aged specimen of $\mathrm{CF}-8 \mathrm{M}$ steel. The data were obtained in HP water containing $0.06-4.5$ $\mathrm{ppm}$ DO at a frequency and rise time of the positive sawtooth wave form of $7.7 \times 10^{-2} \mathrm{~Hz}$ and $12 \mathrm{~s}$, respectively. $R$ values $\left(K_{\min } / K_{\max }\right)$ between 0.3 and 0.95 , and $K_{\max }$ values of $\approx 30-46 \mathrm{MPa} \cdot \mathrm{m}^{1 / 2}$. This range of conditions produced CGRs in the range of $\approx 1 \times 10^{-11}$ to $2 \times 10^{-8} \mathrm{~m} \cdot \mathrm{s}^{-1}$ for the as-received and thermally aged $\mathrm{CF}-8$ specimens. These data and results that were reported previously 53.54 were used to determine the effects of DO and load ratio on CGR over a limited range of $K_{\max }$. The influence of these variables on CGR cannot be obtained with a single set of specimens because of the maximum allowable crack length in a ITCT specimen.

Figures 24-26 show the dependence of CGR on load ratio for as-received and thermally aged $\mathrm{CF}-8$ specimens and thermally aged $\mathrm{CF}-8 \mathrm{M}$ specimens in $\mathrm{HP}$ water containing $\approx 0.1-6.2 \mathrm{ppm}$ DO at $289^{\circ} \mathrm{C}$ for $\mathrm{K}_{\max }$ values of $=30-38 \mathrm{MPa} \cdot \mathrm{m}^{1 / 2}$. The two curves in each figure represent calculated CGRs from correlations developed at ANL 57.58 for wrought SS in high-temperature water containing 0.2 and $8.0 \mathrm{ppm} \mathrm{DO}$ at $\mathrm{K}_{\max }$ values of 30 and 38 MPa $\mathrm{m}^{1 / 2}$, respectively, which encompass minimum and maximum values for these parameters for the data shown in the plots.

The experimental data in Figs. 24 and 25 for as-received and thermally aged $\mathrm{CF}-8$ at $R$ values $\leq 0.8$ are reasonably consistent with predictions of the model for wrought SSs in water containing $0.2 \mathrm{ppm}$ DO. The somewhat higher CGRs for thermally aged $\mathrm{CF}-8 \mathrm{M}$ in Fig. 26 at $R$ values between 0.3 and 0.95 are well represented by the model for water containing $8.0 \mathrm{ppm}$ DO.

The CGR dependence of thermally aged specimens of CF-8 on DO concentration and ECP of Type $304 \mathrm{SS}$ in HP water at an R of 0.95 and $\mathrm{K}_{\max }$ of $35-38 \mathrm{MPa} \cdot \mathrm{m}^{1 / 2}$ is shown in Figs. 27 and 28. The dependence of ECP of Type 304 SS on DO concentration of effluent water from these and previous tests is shown in Fig. 29. The solid lines that depict the CGR data in Figs. 27 and 28 are consistent with the well-known sigmoidal dependence of ECP on DO shown in Fig. 29.

The dependence of the CGRs of aged CF-8 specimens on $K_{\max }$ in water containing 0.3-7.2 ppm DO at $289^{\circ} \mathrm{C}$, i.e., in the plateau region in Fig. 29 where ECP increases slowly with DO concentration, is shown in Fig. 30. The dashed and solid lines represent the CGR 
Table 7. Crack growth rates for CF-8M and CF-8 cast SS $1 T$-compact tension specimens $a_{\text {under cyclic loading }}^{b}$ in $289^{\circ} \mathrm{C}$ water

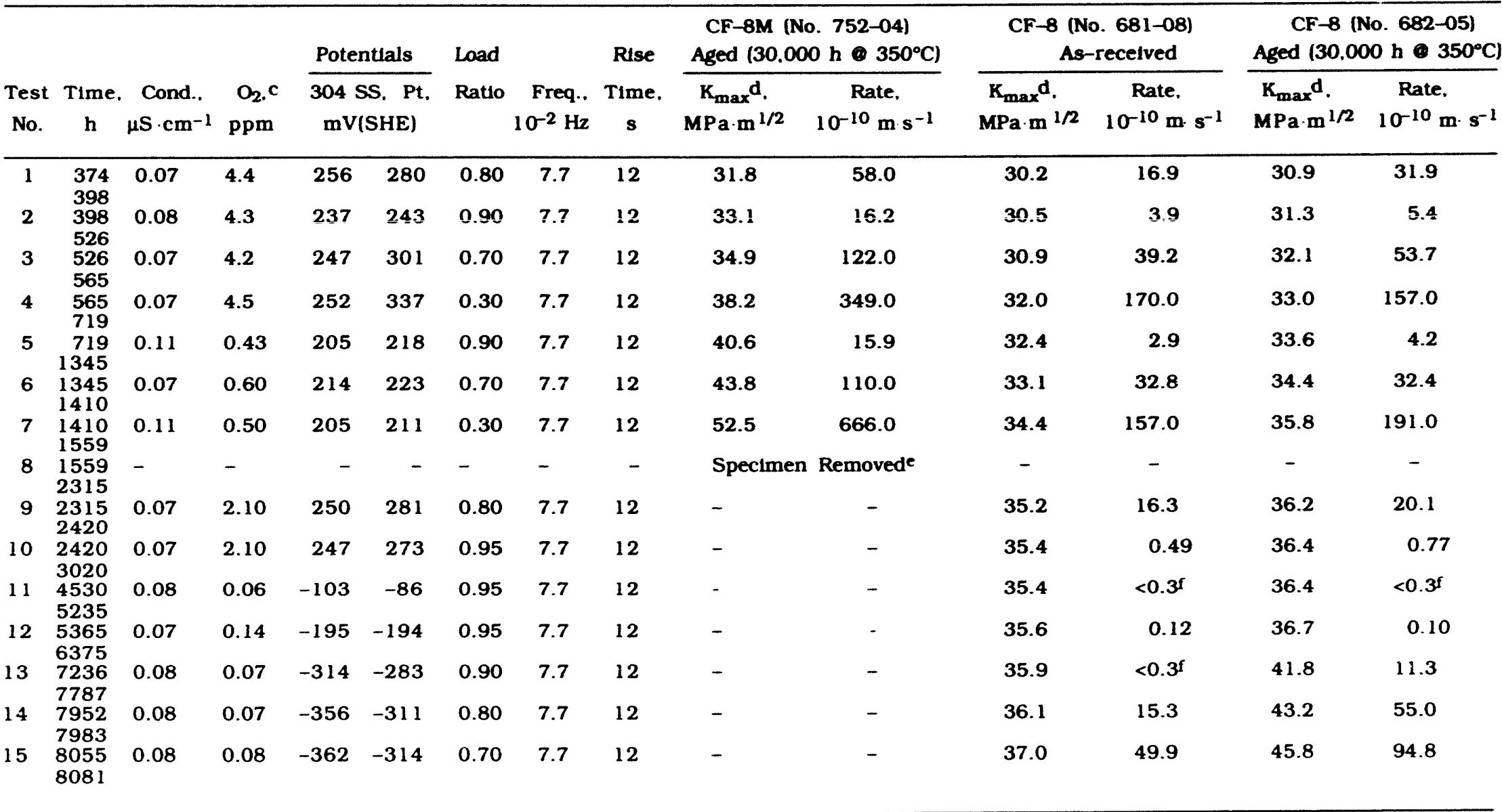

\footnotetext{
a Heat No. 75 for CF-8M containing $27.8 \%$ ferrite (Spec. No. 752-04) and No. 68 for CF-8 containing 23.4\% ferrite (Specs. No. $681-08$ and $682-05$ ). bpositive sawtooth wave form was used.

cEffluent dissolved-oxygen concentrations.

d Stress intensity. $K_{\max }$. values at the end of the time period.

especimen removed from autoclave because the crack length exceeded the maximum allowable value.

f Value based on the sensivity of the crack length measurement $\left(5 \times 10^{-5} \mathrm{~m}\right)$ divided by the test time.
} 

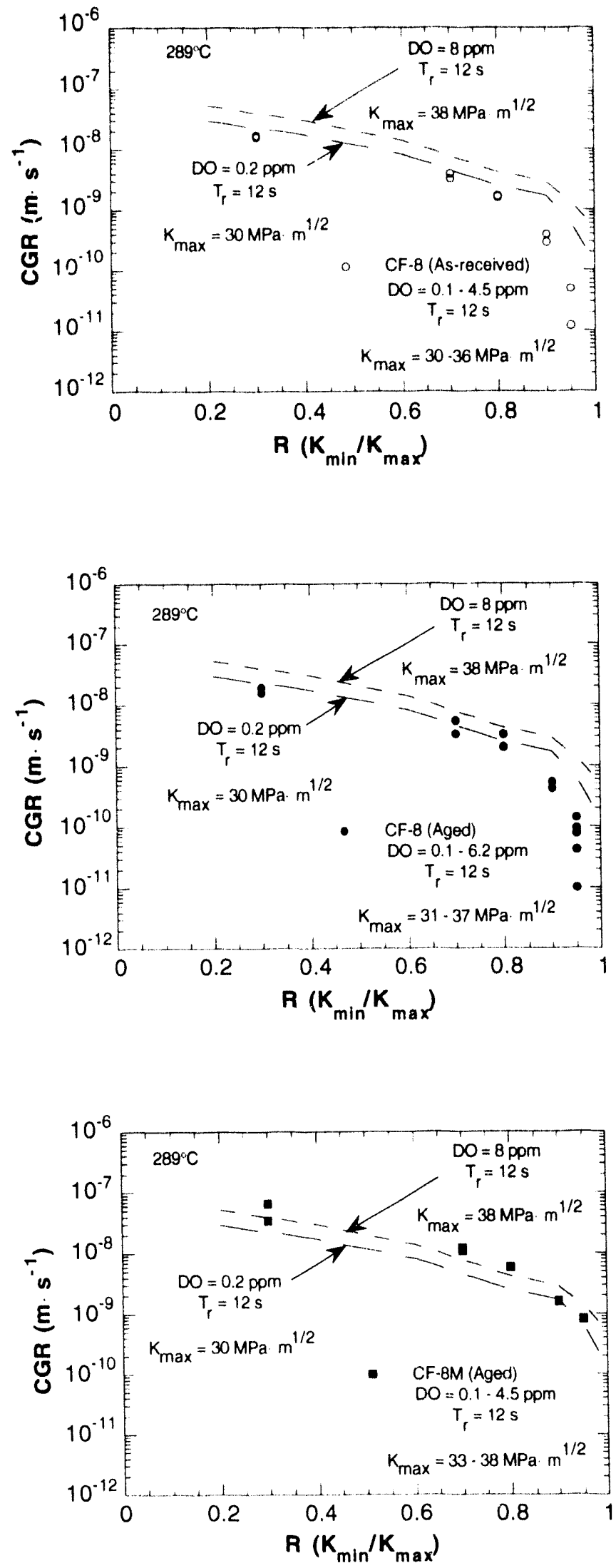

Figure 24.

Dependence of CGR of as-received $C F-8$ SS on load raiso in HP oxygenated water at $289^{\circ} \mathrm{C}$. Dashed curves represent model predictions in water containing 8 and 0.2 ppm DO and stress intensity values of 38 and $30 \mathrm{MPa} \cdot \mathrm{m}^{1 / 2}$, respectively, bound the test conditions for experimental data.
Figure 25.

Dependence of CGR of aged CF-8 SS on load ratio in HP oxygenated water at $289^{\circ} \mathrm{C}$. Dashed curves represent model predictions in water containing 8 and 0.2 ppm DO and stress intensity values of 38 and $30 \mathrm{MPa} \cdot \mathrm{m}^{1 / 2}$, respectively, bound the test conditions for experimental data.
Figure 26.

Dependence of CGR of aged CF-8M SS on load ratio in HP oxygenated water at $289^{\circ} \mathrm{C}$. Dashed curves represent model predictions in water containing 8 and 0.2 ppm DO and stress intensity values of 38 and $30 \mathrm{MPa} \cdot \mathrm{m}^{1 / 2}$, respectively, bound the test conditions for experimental data. 

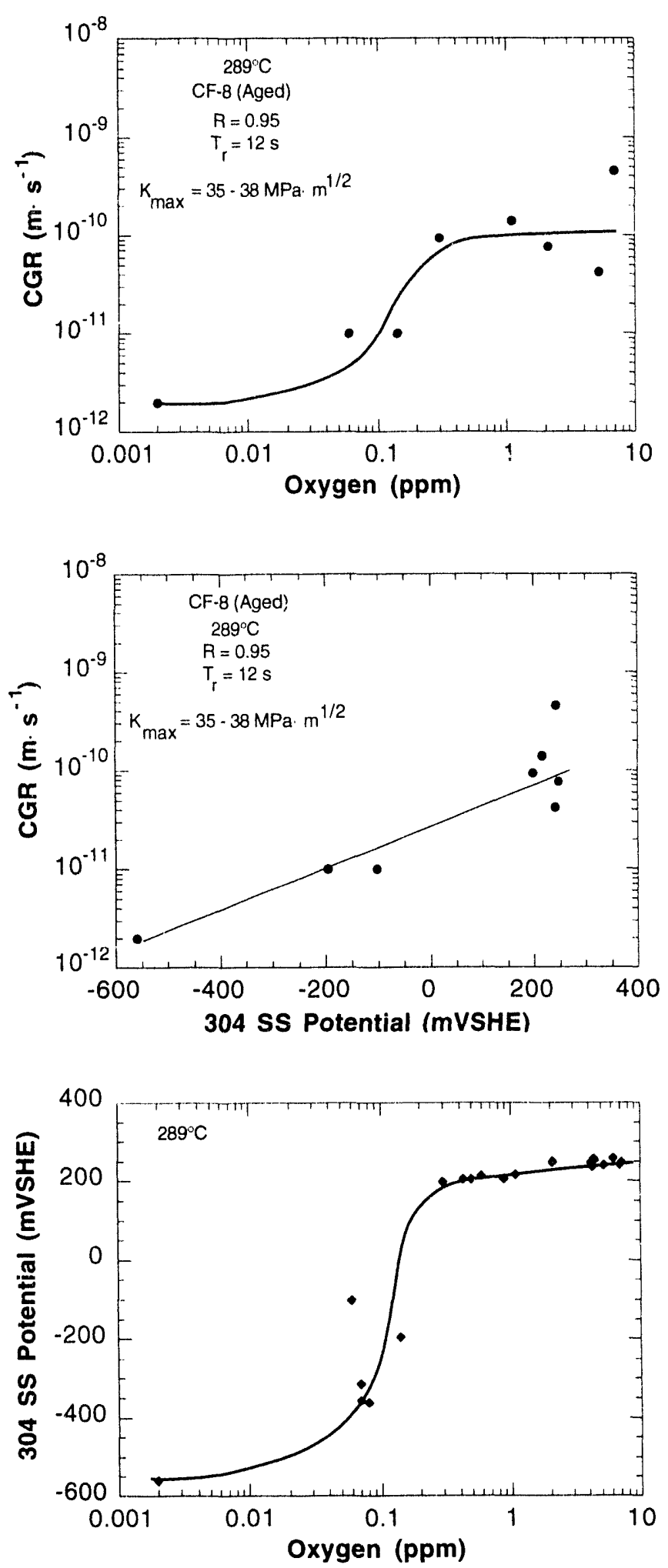

Figure 27.

Dependence of CGR of aged CF-8 SS on DO concentration of HP water at $289^{\circ} \mathrm{C}$
Figure 28.

Dependence of CGR of aged CF-8 SS on ECP of Type 304 SS in HP water at $289^{\circ} \mathrm{C}$
Figure 29.

Dependence of ECP of Type 304 SS on DO concentration of HP water from CGR tests on cast SS specimens at $289^{\circ} \mathrm{C}$

dependence of wrought SSs on $\mathrm{K}_{\max }$ in water containing $8 \mathrm{ppm} \mathrm{DO}$ and in air, respectively, from the model at an $\mathrm{R}$ of 0.95 and a rise time of $12 \mathrm{~s}$. The limited data suggest a threshold stress intensity value of $\approx 35 \mathrm{MPa} \cdot \mathrm{m}^{1 / 2}$ for EAC under these loading conditions, namely a transition from the air curve at lower values of $K_{\max }$ to a water curve at higher values. As 
indicated in Fig. 25, the CGRs of aged CF-8 specimens lie below the calculated curve for water containing $8 \mathrm{ppm}$ DO over the entire range of $R$ values. Most of the data at an $R$ value of 0.95 in Fig. 25 are in the vicinity of what appears to be a threshold $K_{\max }$ for EAC, which may account for the wide variation in CGRs at this $R$ value. This may also be the situation in Fig. 24 for the specimen in the as-received condition, although there are only two data points. The one data point in Fig. 26 for a thermally aged CF-8M specimen at an $R$ value of 0.95 and a $\mathrm{K}_{\max }$ of $\approx 37 \mathrm{MPa} \cdot \mathrm{m}^{1 / 2}$ is indicative of EAC based on model predictions in water containing 8 and $0.2 \mathrm{ppm}$ DO.

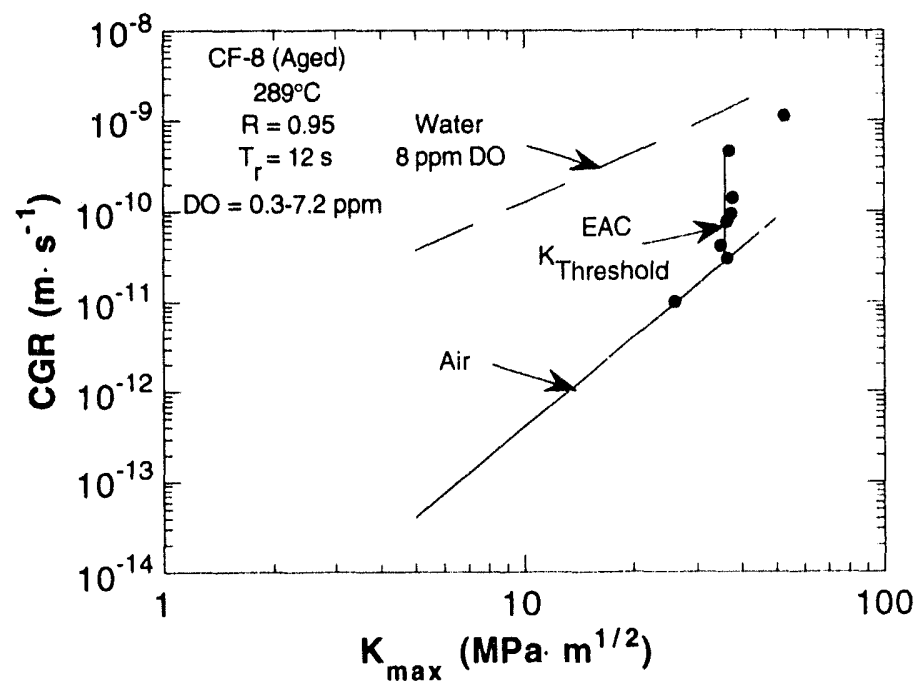

Figure 30.

Dependence of CGR of aged CF-8 SS on $K_{\max }$ in $H P$ oxygenated water at $289^{\circ} \mathrm{C}$. Dashed and solid lines represent model predictions in water containing 8 ppm DO and in air. respectively, at $R$ value of 0.95 and rise time of $12 \mathrm{~s}$.

Figures 31-33 show the morphology of fatigue and stress corrosion cracks in the asreceived $C F-8$ and thermally aged $C F-8$ and $-8 \mathrm{M}$ specimens. The 1TCT specimens were sectioned vertically, and one-half of each specimen was split in the plane of the crack in liquid nitrogen. The corrosion-product film was removed from the fracture surface by a chemical process to reveal the morphology of the underlying material. The intact portion of the specimen that encompassed the crack was polished and etched to corroborate the mode of crack propagation and also to determine if crack branching had occurred during the test. The total crack lengths at the end of the test were compared with values obtained from the DC potential-drop technique. As in the case of previous specimens, 53 the crack paths in Figs. 31-33 favor the ferrite phase or ferrite/austenite phase boundaries. The path traverses austenite grains when their orientation would require the crack to deviate significantly from the crack plane. Scanning electron photomicrographs of the fracture surfaces reveal somewhat featureless transgranular cracks in the ferrite and austenite phases.

Fracture-mechanics CGR test 3 are in progress on three 1TCT specimens of CF-3 cast SS in the as-received and thermally aged conditions to further explore the effects of thermal aging on corrosion-fatigue behavior and to establish the threshold stress intensity for EAC as a function of load ratio in HP oxygenated water at $289^{\circ} \mathrm{C}$. 


\begin{tabular}{|c|c|c|}
\hline HEAT TREATMENT & LOAD CONDITIONS & ENVIRONMENT \\
As-received & $\mathrm{K}_{\max }=30-37 \mathrm{MPa} \cdot \mathrm{m}^{1 / 2}$ & HP Water; $0.07-4.5 \mathrm{ppm}$ DO \\
& $\mathrm{R}=0.3-0.95 ;$ Freq. $=0.077 \mathrm{~Hz}$ & $289^{\circ} \mathrm{C}$ \\
\hline
\end{tabular}

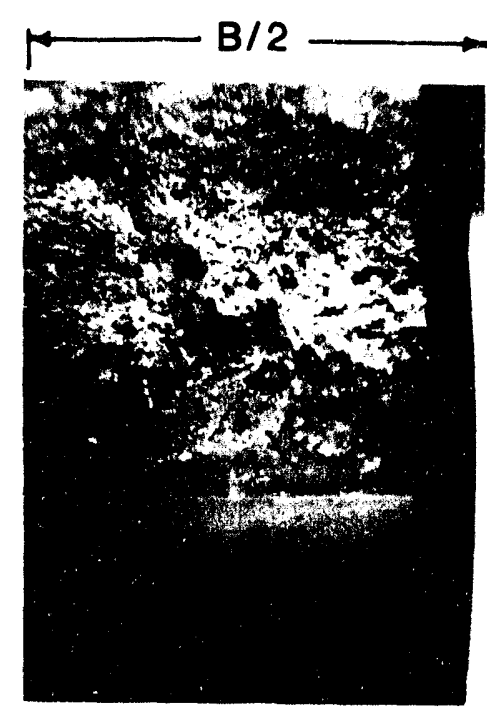

OUTER SURFACE

FRACTURE SURFACE
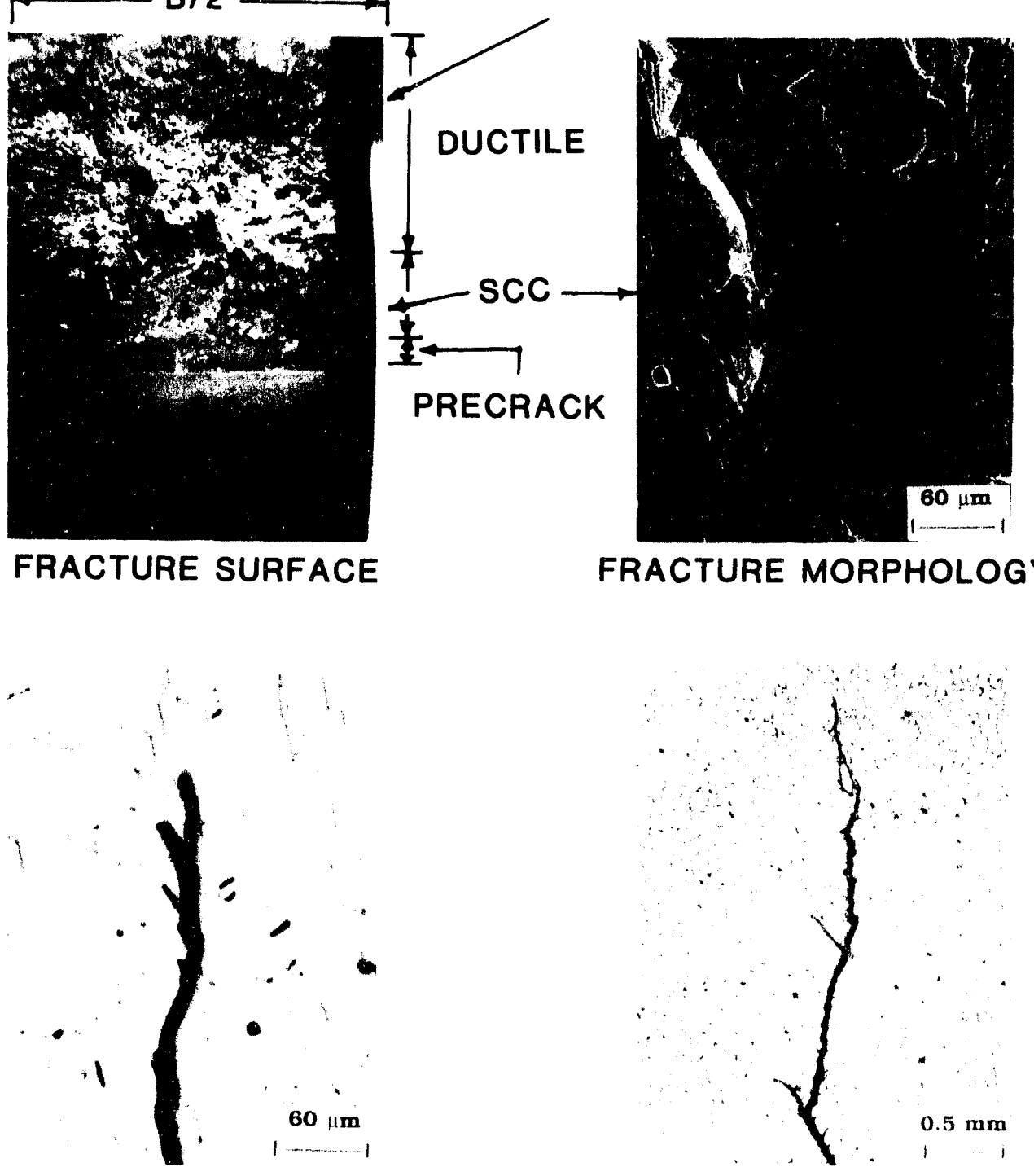

CRACK TIP REGION

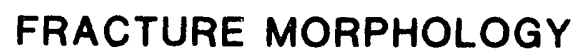

Figure 31. Crack path, fracture surface, and fracture morphology of as-received 1TCT specimen of CF-8 cast SS (No. 681-08) after crack growth experiment in $H P$ water at $289^{\circ} \mathrm{C}$ 


\begin{tabular}{|c|c|c|}
\hline HEAT TREATMENT & LOAD CONDITIONS & ENVIRONMENT \\
$350^{\circ} \mathrm{C}$ for $30,000 \mathrm{~h}$ & $\mathrm{~K}_{\max }=30-46 \mathrm{MPa} \cdot \mathrm{m}^{1 / 2}$ & HP Water; $0.07-4.5 \mathrm{ppm}$ DO \\
& $\mathrm{R}=0.3-0.95 ;$ Freq. $=0.077 \mathrm{~Hz}$ & $289^{\circ} \mathrm{C}$ \\
\hline
\end{tabular}

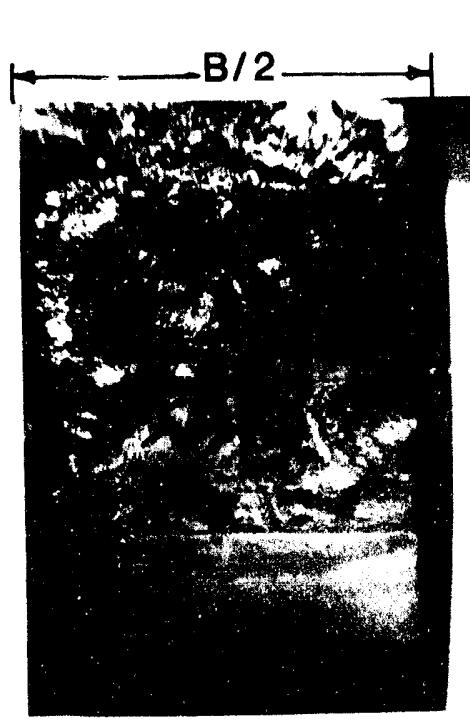

FRACTURE SURFACE

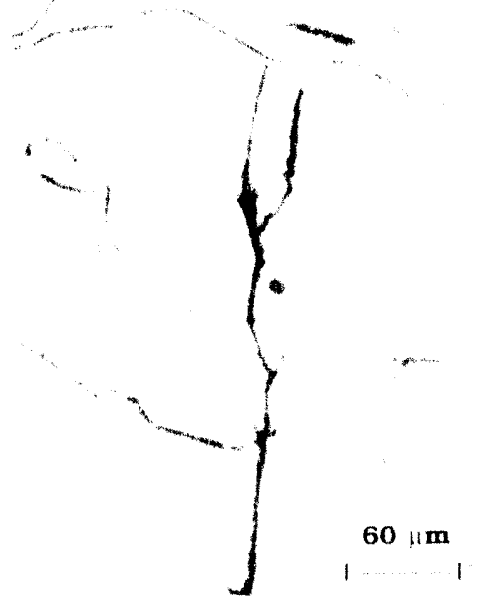

CRACK TIP REGION
OUTER SURFACE

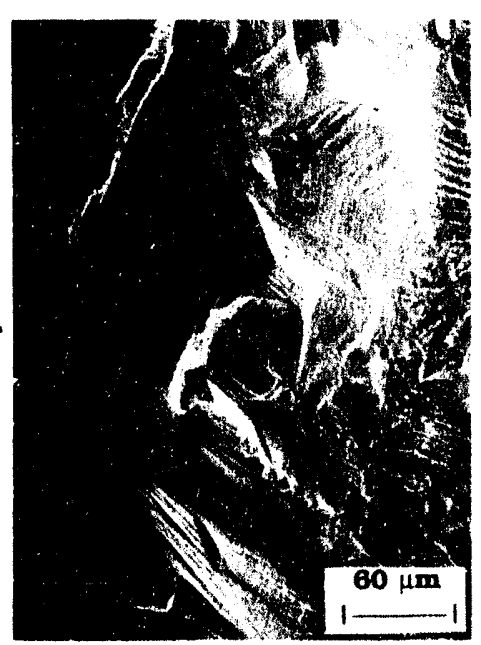

FRACTURE MORPHOLOGY

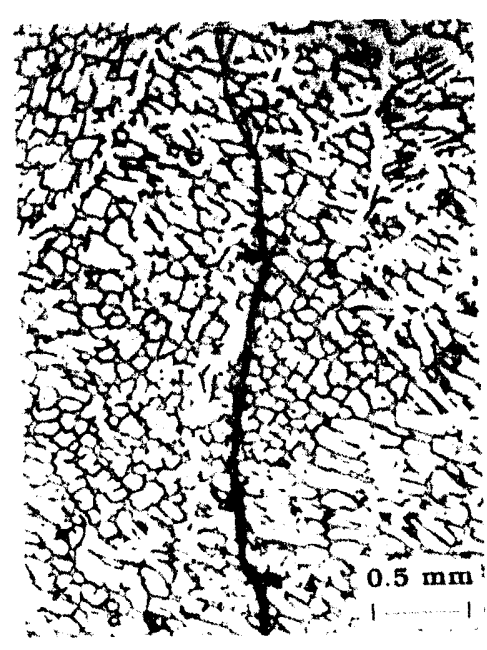

CRACK PROPAGATION

Figure 32. Fracture surface and fracture morphology of thermally aged 1TCT specimen of CF-8 cast SS (No. 682-05) after crack growth experiment in air at $289^{\circ} \mathrm{C}$ 


\begin{tabular}{|c|c|c|}
\hline HEAT TREATMENT & LOAD CONDITIONS & ENVIRONMENT \\
$350^{\circ} \mathrm{C}$ for $30,000 \mathrm{~h}$ & $\mathrm{~K}_{\max }=30-53 \mathrm{MPa} \cdot \mathrm{m}^{1 / 2}$ & HP Water: $0.07-4.5 \mathrm{ppm} \mathrm{DO}$ \\
& $\mathrm{R}=0.3-0.95 ;$ Freq. $=0.077 \mathrm{~Hz}$ & $289^{\circ} \mathrm{C}$ \\
\hline
\end{tabular}

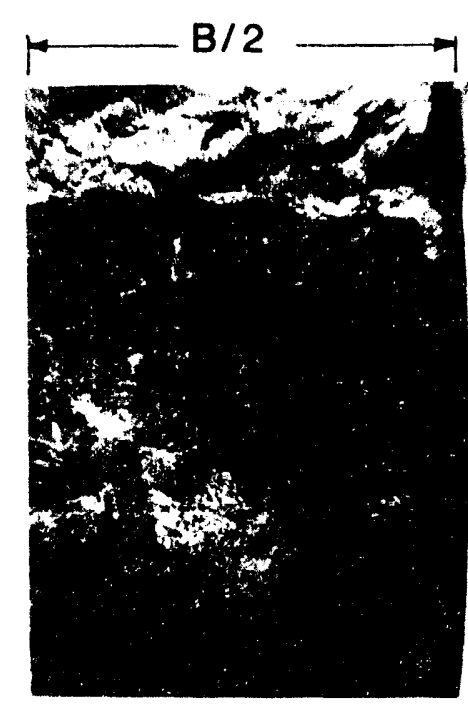

FRACTURE SURFACE

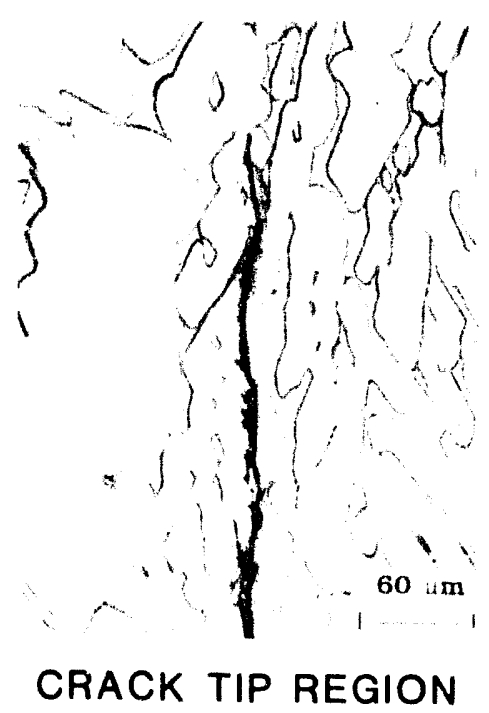

\section{OUTER SURFACE}

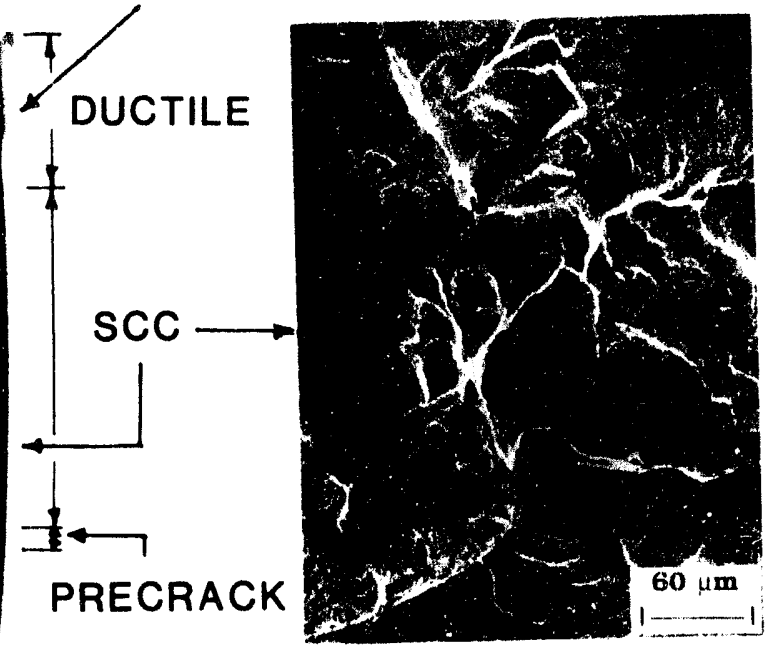

FRACTURE MORPHOLOGY

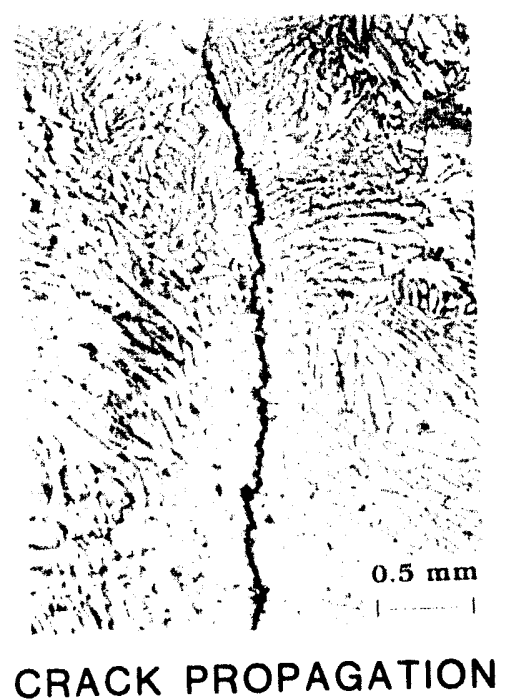

Figure 33. Fracture surface and fracture morphology of thermally aged 1TCT specimen of CF-8M cast SS (No. 752-04) after crack growth experiment in $\mathrm{HP}$ water at $289^{\circ} \mathrm{C}$ 


\section{Irradiation-Assisted Stress Corrosion Cracking of Austenitic SS}

In recent years, failures of reactor-core internal components in both BWRs and PWRs have increased after accumulation of relatively high fluence $\left(>5 \times 10^{20} \mathrm{n} \cdot \mathrm{cm}^{-2}, \mathrm{E}>1 \mathrm{MeV}\right)$. The general pattern of the observed failures indicates that as nuclear plants age and neutron fluence increases, various apparently nonsensitized austenitic SSs become susceptible to intergranular failure. Some components (e.g., BWR core shroud, control blade handle and sheath) are known to have cracked under minimal applied stress. Although most failed components can be replaced, some safety-significant structural components (e.g.. BWR top guide, shroud, and core plate) would be very difficult or impractical to replace. Therefore, the structural integrity of these components after accumulation of high fluence has been a subject of concern, and extensive research has been conducted to provide an understanding of this type of degradation, which is commonly known as irradiation-assisted stress corrosion cracking (IASCC).

In the mid-1960s, investigators began to implicate impurities such as $\mathrm{Si}, \mathrm{P}$, and $\mathrm{S}$ in IASCC failure of components fabricated from solution-annealed nonsensitized austenitic SS. However, in direct contradiction of the earlier beliefs and initially encouraging test results obtained from high-purity (HP) Type 348 and 304 austenitic SSs, several investigators recently have reported results from slow-strain-rate-tensile (SSRT) and in-reactor tests indicating that resistance to IASCC failure of other HP heats of Type 304 and 348 SS is no better than that of commercial-purity (CP) materials. Therefore, the issue of superior performance of HP materials and the mechanisms of IASCC appear to be far from established. In general, heat-to-heat variation in susceptibility to IASCC has been observed to be very significant regardless of material grade, even among similar HP materials containing virtually identical chemical compositions. This seems to cast serious doubt not only on the role of grain-boundary segregation of impurities (i.e., Si, P, or S) but also on the premise that $\mathrm{Cr}$ depletion is the only important mechanism of IASCC. Although significant grain-boundary $\mathrm{Cr}$ depletion can play an important role in IASCC of thermally sensitized and irradiated components, we suspect that another primary process that involves trace impurity elements, which are not specified in the ASTM specifications, may contribute to IASCC of solution-annealed materials. These elements, which have been overlooked by most investigators, are typically associated with iron and steel making processes and with fabrication of the actual components, i.e., elements associated with flux compounds, cutting agents, recycled scrap, and strengthening additions. In the present study, results of grainboundary chemical analysis by Auger electron spectroscopy (AES) of specimens obtained from Type 304 SS components irradiated in operating BWRs were examined to determine the role of trace elements.

Other topics contained in this report are (a) status of the Halden-reactor irradiation of austenitic SS alloys irradiated to a fluence of $\approx 0.43 \times 10^{21} \mathrm{n} \cdot \mathrm{cm}^{-2}, \mathrm{E}>1 \mathrm{MeV}$ ), (b) progress of the assembly of a $\mathrm{J}-\mathrm{R}$ test facility that will be used to determine fracture toughness of specimens irradiated in the Halden reactor, and (c) initial data that show the effects of ECP and DO on IGSCC of irradiated BWR specimens.

\subsection{Role of Trace Elements in SCC of Irradiated Austenitic SSs (H. M. Chung, W. E. Ruther, and J. E. Sanecki)}

In previous publications, 59,60 we have reported results of AES analyses of several heats 
of Types 304 SS. Detailed analyses of grain-boundary chemistry were conducted on BWR neutron-absorber tubes that were fabricated from two heats of HP Type 304 SS of virtually identical bulk chemical composition (Heats HP304-A and $-\mathrm{CD}$. Table 8) but exhibiting a

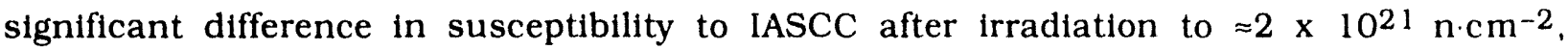
$\mathrm{E}>1 \mathrm{MeV}$ (Fig. 34). Grain-boundary concentrations of $\mathrm{Cr}, \mathrm{Ni}, \mathrm{Si}, \mathrm{P}, \mathrm{S}$, and $\mathrm{C}$ of the two HP heats were virtually identical. However, grain boundaries of the crack-resistant material contained less $\mathrm{N}$ and more $\mathrm{B}$ and $\mathrm{Li}$ than those of the susceptible material. This observation indicates that, besides the deleterious effect of grain-boundary $\mathrm{Cr}$ depletion, grain-boundary segregation of $\mathrm{N}$ and $\mathrm{B}$ plays an important role in IASCC. That is, lower $\mathrm{N}$ and higher $\mathrm{B}$ concentrations on grain boundaries are beneficial in that they suppress IASCC.

Table 8. Chemical composition and fluence of HP and CP Type 304 SS BWR components

\begin{tabular}{|c|c|c|c|c|c|c|c|c|c|c|c|c|}
\hline \multirow{2}{*}{$\begin{array}{l}\text { Heat } \\
\text { ID No. }\end{array}$} & \multicolumn{9}{|c|}{ Composition (wt.\%) } & \multirow{2}{*}{$\begin{array}{l}\text { Source } \\
\text { Code }\end{array}$} & \multirow{2}{*}{$\begin{array}{l}\text { Service } \\
\text { Reactor }\end{array}$} & \multirow{2}{*}{$\begin{array}{c}\text { Fluence } \\
10^{21} \\
\mathrm{n} \cdot \mathrm{cm}^{-2}\end{array}$} \\
\hline & $\mathrm{Cr}$ & Ni & $\mathrm{Mn}$ & C & $\mathbf{N}$ & B & $\mathrm{Si}$ & $\mathrm{P}$ & s & & & \\
\hline HP304-A & 18.50 & 9.45 & 1.53 & 0.018 & 0.100 & $<0.001$ & $<0.03$ & 0.005 & 0.003 & V-ATa & BWR-B & $0.2-1.4$ \\
\hline HP304-B & 18.30 & 9.75 & 1.32 & 0.015 & 0.080 & $<0.001$ & 0.05 & 0.005 & 0.005 & $\mathrm{~V}-\mathrm{AT}^{\mathrm{a}}$ & BWR-B & $0.2-1.4$ \\
\hline HP304-CD & 18.58 & 9.44 & 1.22 & 0.017 & 0.037 & 0.001 & 0.02 & 0.002 & 0.003 & V-ATa & BWR-B & $0.2-1.4$ \\
\hline HP304-CD & 18.58 & 9.44 & 1.22 & 0.017 & 0.037 & 0.001 & 0.02 & 0.002 & 0.003 & QC-ATa & BWR-QC & 2.0 \\
\hline CP304-A & 16.80 & 8.77 & 1.65 & $0.08 \mathrm{~b}$ & 0.052 & - & 1.55 & $0.045^{b}$ & $0.030^{b}$ & BL-ATC & BWR-Y & $0.2-2.0$ \\
\hline CP304-B & $18.0-20.0$ & 8-10.5 & $2.00^{b}$ & $0.08^{\mathrm{b}}$ & - & - & $1.00^{\mathrm{b}}$ & $0.045^{b}$ & $0.030^{\mathrm{b}}$ & $L C-S^{d}$ & BWR-LC & $0.5-2.6$ \\
\hline
\end{tabular}

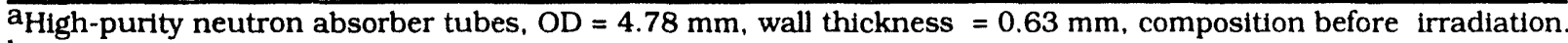

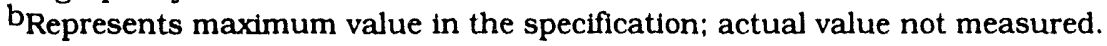

$c_{C}$ ommercial-purity absorber tubes, $\mathrm{OD}=4.78 \mathrm{~mm}$, wall thickness $=0.79 \mathrm{~mm}$, composition after irradiation.

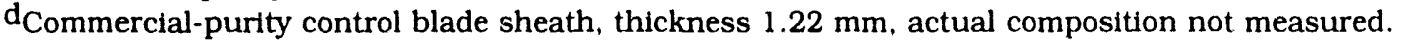

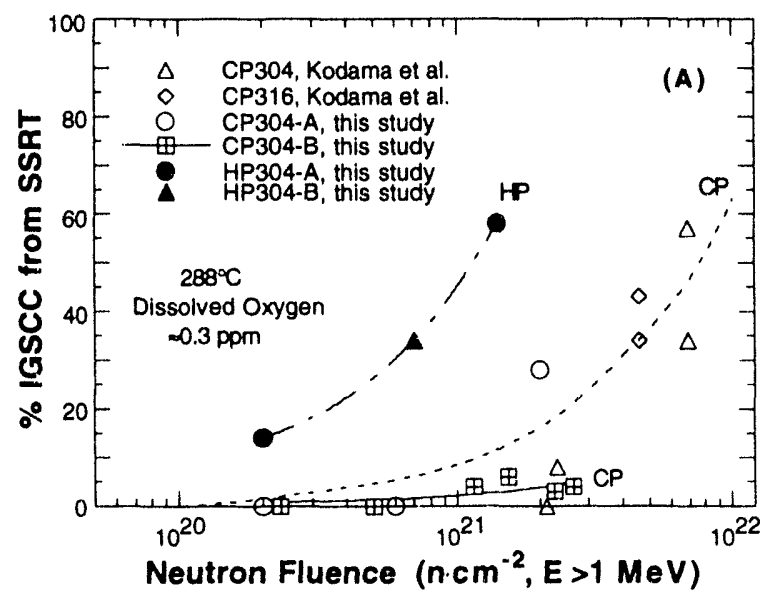

Figure 34.

Percent IGSCC us. fluence for HP and CP Type 304 SS BWR specimens from SSRT tests at $289^{\circ} \mathrm{C}$ in simulated BWR water. Specimens irradiated to $2 \times 10^{21} \mathrm{n} \cdot \mathrm{cm}^{-2}$ were analyzed to determine role of trace impurities.

Significant heat-to-heat variation similar to that of Ref. 59 has been also reported for HP heats of Type 348 SS by Garzarolli et al.61 Contrary to their earlier observation of superior resistance for one of the $\mathrm{HP}$ heats both in a BWR and PWR, 62 three similar HP heats of Type 348 SS of virtually identical chemical composition exhibited poor resistance to LASCC in a PWR.61 It has been also reported recently that Types 304 and 316 SS. irradiated to a fluence of $\approx 3 \times 10^{21} \mathrm{n} \cdot \mathrm{cm}^{-2}(\mathrm{E}>1 \mathrm{MeV})$ at $50^{\circ} \mathrm{C}$ in the Japan Material Testing Reactor (JMTR), exhibited a surprisingly high susceptibility to IGSCC in SSRT tests 
at $288^{\circ} \mathrm{C}$ despite the likelihood that grain-boundary $\mathrm{Cr}$ depletion is negligible at such a low irradiation temperature. These observations 60,61 , $^{*}$ strongly suggest that an unidentifled process other than grain-boundary $\mathrm{Cr}$ depletion or radiation-induced segregation (RIS) of primary impurities 60.63 (such as Si, P. C, or S) plays an important role in IASCC.

We have suspected for some time that IASCC may be influenced by minor impurity and/or trace elements that are not specified in the ASTM specification. Besides the $\mathrm{Cr}, \mathrm{Ni}$, $\mathrm{Mn}, \mathrm{Si}, \mathrm{P}, \mathrm{S}, \mathrm{C}$, and $\mathrm{N}$ normally identified in the ASTM specification, other minor impurities and trace elements may have been overlooked by most investigators. These elements originate mostly from (a) flux material used to make iron and steel, (b) materials used to facilitate fabrication and shaping of components, (c) recycled scrap, and (d) ferrovanadium added to increase the strength of steels, which may include $\mathrm{Ca}, \mathrm{Al}, \mathrm{F}, \mathrm{Cu}, \mathrm{Mg}, \mathrm{B}, \mathrm{Te}, \mathrm{Se}, \mathrm{BI}$, $\mathrm{Pb}$, and $\mathrm{V}$. Most of these elements were found to be present in the HP and CP Type 304 SS specimens from BWR neutron-absorber tubes and a control-blade sheath (Fig. 34) that we analyzed by AES.

Surprisingly, the susceptibility to IGSCC correlates well with the grain-boundary concentrations of $F$ and $V$. AES spectra of these elements are shown in Fig. 35 . The primary Auger electron peak (derivative peak) for $\mathrm{F}$ is at $650 \mathrm{eV}$ and two minor peaks occur at 605 and $625 \mathrm{eV}$, respectively. Because the primary peak of $\mathrm{F}$ overlaps the strong peak of $\mathrm{Fe}$ at $651 \mathrm{eV}$, it is easy to overlook the presence of $\mathrm{F}$ in the steels. Fluorine originates from welding electrodes or fluorspar, a compound frequently used as flux material by many producers of iron and steel (or from recycled steel that contains $F$ ), whereas $V$ originates from ferrovanadium; a strengthening addition used extensively by most steel makers. $\mathrm{CaF}_{2}$ is a major constituent $(\approx 75 \%)$ of fluorspar, a neutral flux. Any amount of scrap iron and steel originally produced with the use of fluorspar and recycled could introduce $F$ into a new heat of steel.

A survey of AES spectra from a variety of iron and steels in the literature indicated that $\mathrm{F}$ was absent or negligible in some heats, e.g., nonirradiated AISI 3340 steel $(3.4 \mathrm{Ni}-1.9 \mathrm{Cr}-$ $2.2 \mathrm{C}-0.03 \mathrm{Sb}), 64$ nonirradiated Type $304 \mathrm{SS}, 65$ nonirradiated high-purity Fe doped with $0.09 \mathrm{wt} \% \mathrm{~B}, 66$ and nonirradiated and irradiated $9 \mathrm{Cr}-1 \mathrm{~W}-2 \mathrm{Mn}$ steel.67 However, in some heats of material, intensities of the $605-$ and $625-\mathrm{eV}$ peaks of $\mathrm{F}$ were significant, e.g., irradiated Type 304 SS, 68 nonirradiated Type 304 SSs, 69 nonirradiated Fe-1.7C-3.2Mn and $\mathrm{Fe}-1.7 \mathrm{C}-3.0 \mathrm{Ni}, 70$ and irradiated Nimonic PE 16.71 The relative grain-boundary concentrations for $F$ were determined based on the ratio of the amplitude of secondary Augerelectron peak of $\mathrm{F}(605 \mathrm{eV})$ to the amplitude of the primary Fe peak; actually the sum of the primary $\mathrm{Fe}$ and $\mathrm{F}$ peaks $(650 \mathrm{eV})$. The relative concentrations of $\mathrm{F}$, obtained from ductile (denoted " $D$ "), faceted featureless (denoted "U"), and intergranular (denoted "I") fracture surfaces of BWR specimens of Heats CP304-A, CP304-B, HP304-CD, and HP304-A irradiated to $\approx 2 \times 10^{21} \mathrm{n} \cdot \mathrm{cm}^{-2}(\mathrm{E}>1 \mathrm{MeV})$, are shown in Fig. 36. In the figure, the righthand-side insets show results obtained from duplicate specimens. In Fig. 37, similar results of AES analyses of $\mathrm{V}$ are shown.

\footnotetext{
* M. Kodama, J. Morisawa, S. Nishimura, K. Asano, S. Shima, and K. Nakata, Stress Corrosion Cracking and Intergranular Corrosion of Austentic Stainless Steels Irradiated at $323 \mathrm{~K}$, in Proc. 6th Intl. Conf. on Fusion Reactor Materials, September 27-October 1, 1993, Stresa, Italy, in press.
} 
In two materials that exhibited relatively good resistance to IGSCC (i.e., CP304-B sheath and HP304-CD neutron-absorber tube, Fig. 34), the concentrations of F and $V$ were relatively low or negligible. The HP304-CD neutron-absorber tube exhibited superior resistance to IASCC based on in-reactor service experience. ${ }^{72}$ In contrast. the two materials that exhibited relatively poor resistance (i.e., CP3O4-A and HP'304-A neutron-absorber tubes, Fig. 34) showed relatively high concentrations of $F$ and $V$ on grath boundaries and in grains. Based on data in Figs. 36 and 37, grain-boundary concentrations of $F$ and $V$ were plotted in Figs. 38A and 38B, respectively, as function of \%IGSCC measured from SSRT tests of the BWR-irradiated specimens.

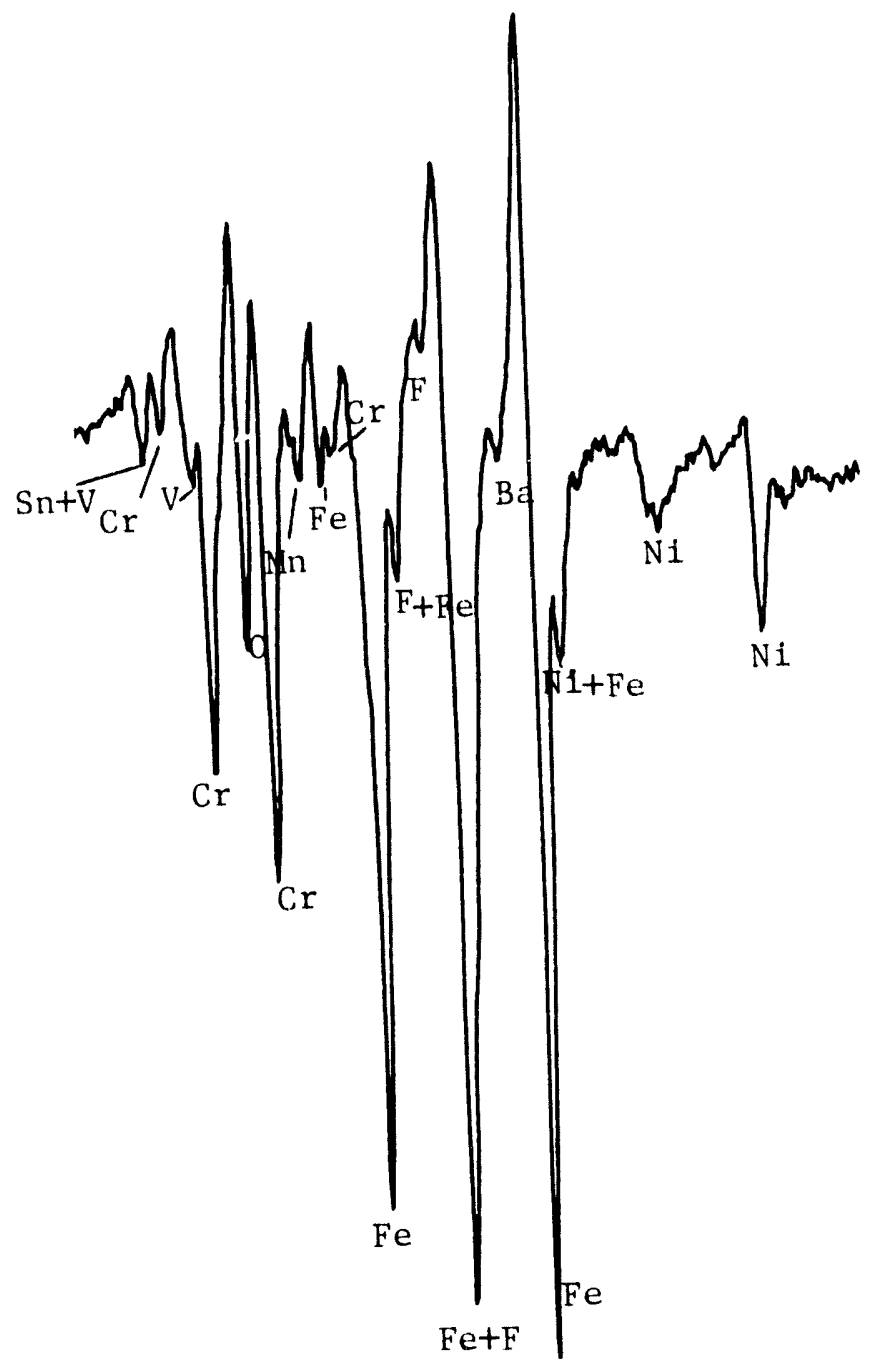

Figure 35. Auger peaks from minor impurity elements in typical AES spectra obtained from BWR specimens of Type 304 SS irradiated to $\approx 2 \times 10^{21} \mathrm{n} \cdot \mathrm{cm}^{-2}$

Fluorine could combine with $\mathrm{H}$ to form HF molecules, which react with water. Vanadium is known to form many complex compounds with impurity elements, many of which are known to be readily soluble in water, e.g., vanadium fluorides. Vanadium is also characterized by its slow transmutation to $\mathrm{Cr}$ by thermal neutrons. Although, as Fig. 38 shows, susceptibility to IASCC appears to be promoted by the presence of $\mathrm{F}$ and/or $\mathrm{V}$ atoms on grain boundaries, a mechanism by which this might occur is not known. 

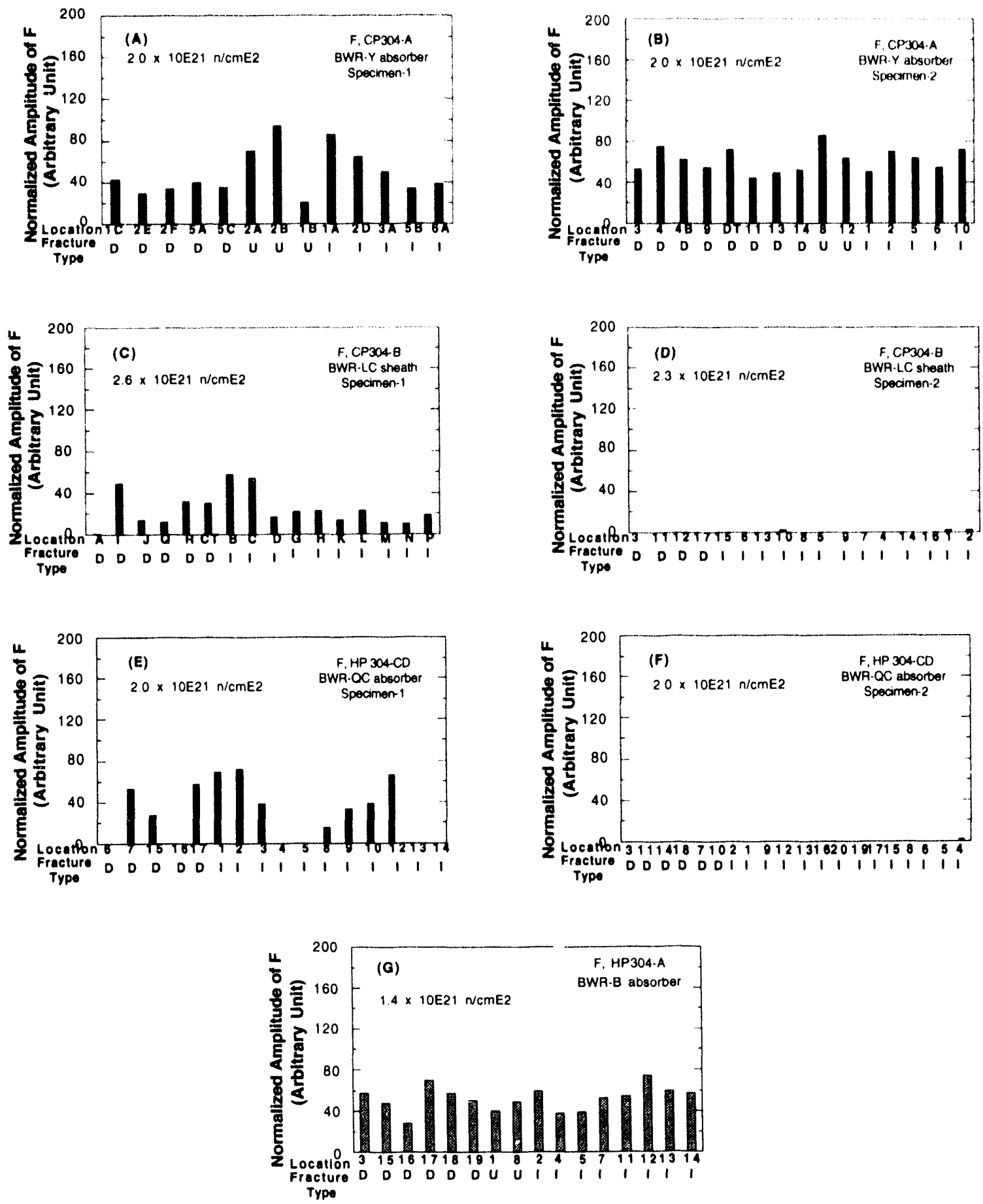

Figure 36. Intensities of $F$ signal (605 eV) from ductile (denoted by " $D$ "), intergranular ("I"), and faceted ("U") fracture surfaces of CP and HP Type 304 SS BWR specimens irradiated to $\approx 2 \times 10^{21} \mathrm{n} \cdot \mathrm{cm}^{-2}$ 

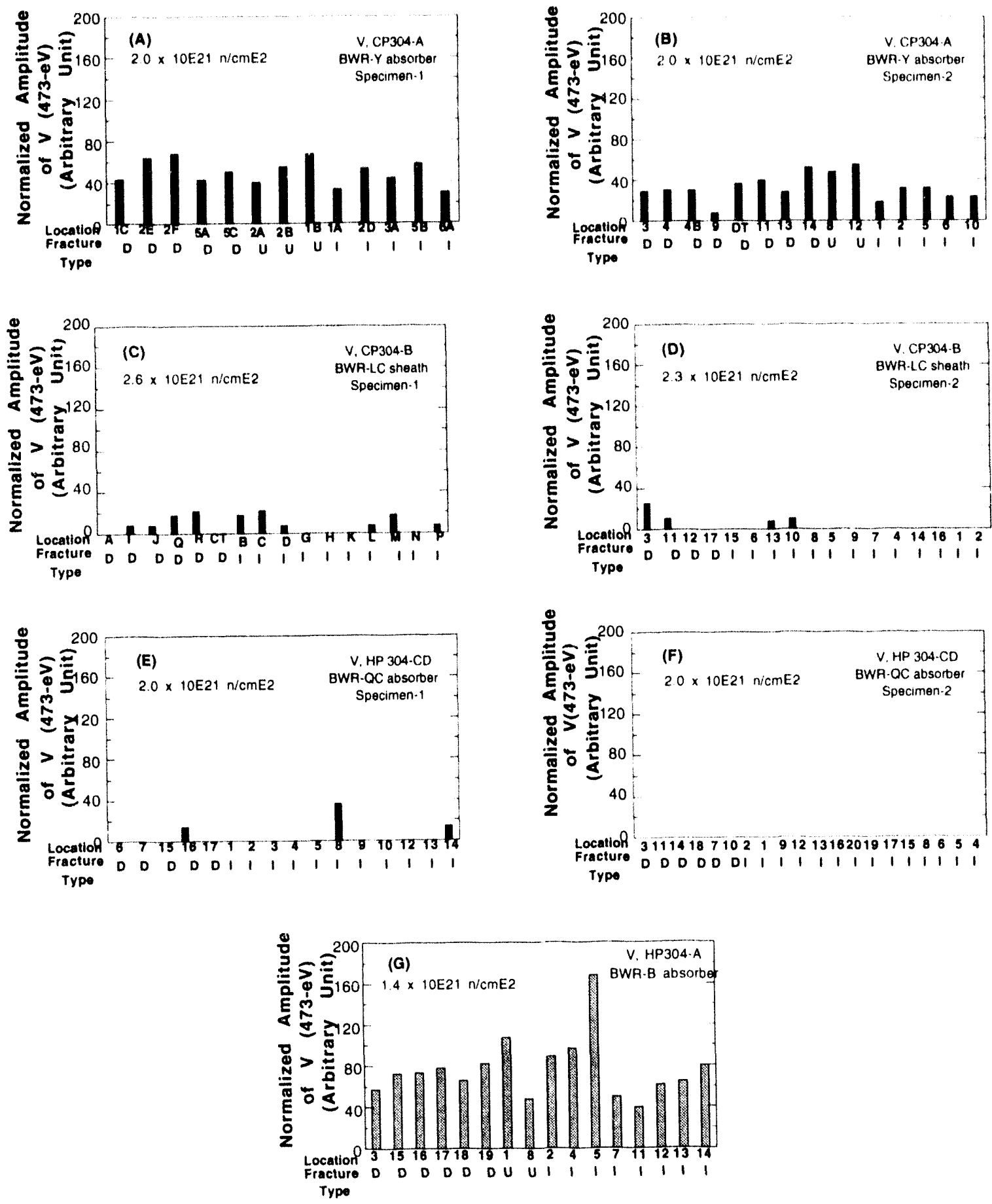

Figure 37. Intensities of $V$ signal (473 eV) from ductile (denoted by " $D$ "), intergranular ("I"), and faceted ("U") fracture surfaces of CP and HP Type 304 SS BWR specimens irradiated to $\approx 2 \times 10^{21} \mathrm{n} \cdot \mathrm{cm}^{-2}$

It seems that $\mathrm{F}$ atoms are preferentially trapped at certain types of precipitates. For example, the IASCC-resistant HP304-CD heat contained $\mathrm{Cu}$-rich precipitates in relatively high number density, and results of Auger electron analysis indicate that $F$ atoms are trapped at these precipitates. This is shown in Fig. 39. 

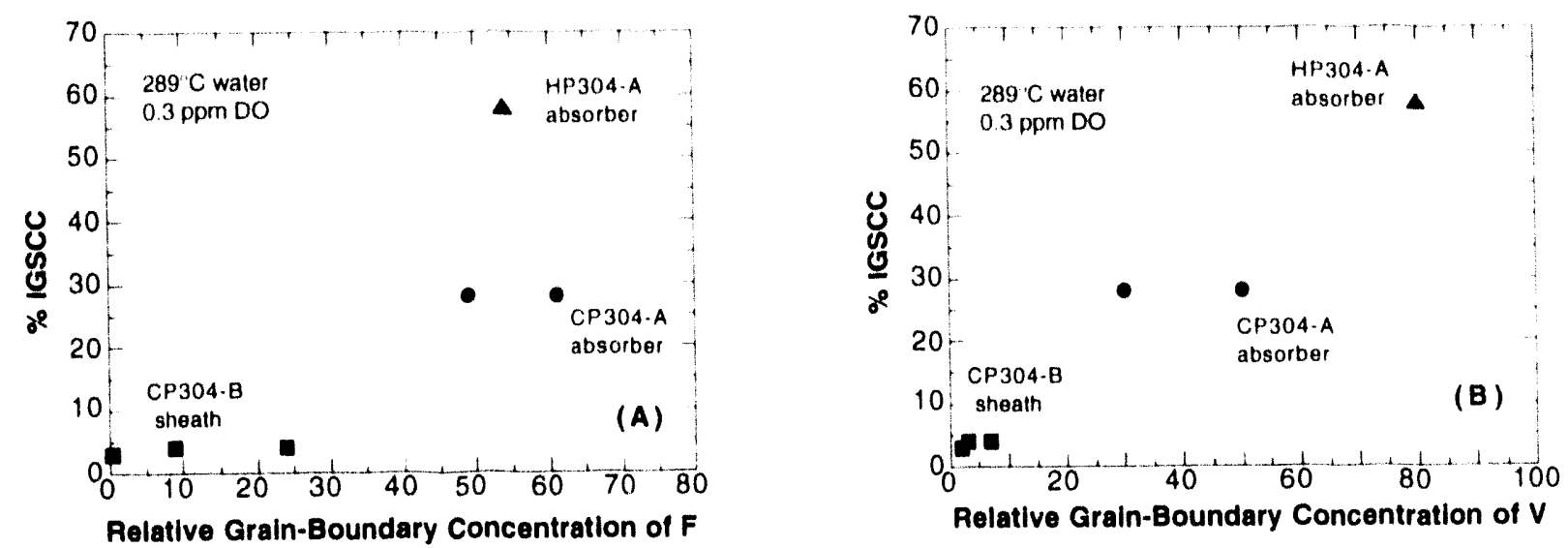

Figure 38. Grain-boundary concentration of (A) $F$ and (B) $V$ vs. \% IGSCC measured from SSRT tests of BWR neutron-absorber tubes and control-blade sheath irradiated to $\approx 2 \times 10^{21} \mathrm{n} \cdot \mathrm{cm}^{-2}(\mathrm{E}>1 \mathrm{MeV})$

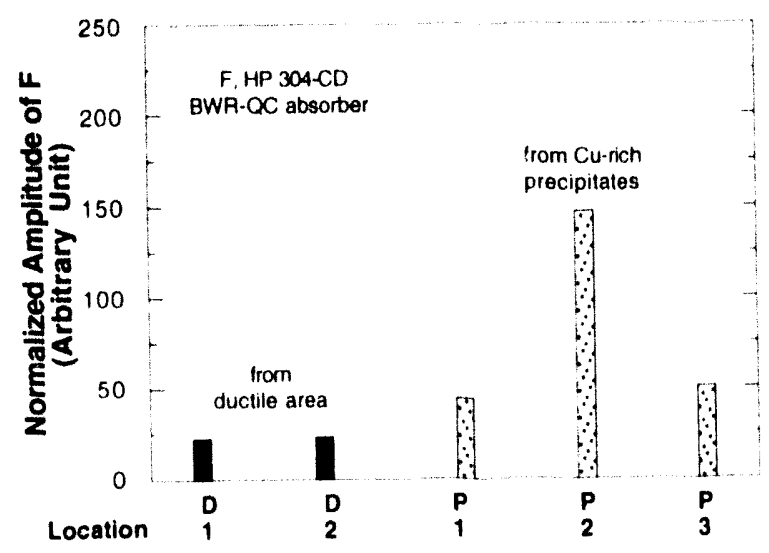

Figure 39.

Relative Auger electron intensities of $F$ from ductile-fracture regions and from $\mathrm{Cu}-$ rich precipitates in IASCC-resistant HP3O4 SS neutron-absorber tubes irradiated to $2.0 \times 10^{21} \mathrm{n.cm}-2$, indicating that $\mathrm{F}$ atoms are trapped at $\mathrm{Cu}$-rich precipitates

\subsection{Effect of Water Chemistry on IASCC Susceptibility (H. M. Chung and W. E. Ruther)}

The effect of water chemistry on IASCC of BWR components has been assumed by many investigators to be similar to that for IGSCC of thermally sensitized austenitic SSs. However, actual data that show the influence of water chemistry on susceptibility of irradiated materials to IASCC are very limited. Whether IASCC can be suppressed effectively by a reduction of the ECP of the material and what the threshold level of ECP may be have not been well established. Data for effects of water chemistry on IASCC have been reported for a few heats of Types 304 and 316 SS. ${ }^{73-76}$ In Fig. 40, the effects of ECP and DO on $\%$ IGSCC and average CGR measured from SSRT tests are summarized. In the figure, results obtained from the present investigation on BWR absorber tubes and sheath are also included to give a comparison with data reported in the literature. Only the data obtained for a similar fluence range $\left(1.2-3.5 \times 10^{21} \mathrm{n} \cdot \mathrm{cm}^{-2}\right)$ have been included in each plot. From Fig. 40, unlike the dependence of IGSCC of thermally sensitized materials on ECP or DO concentration in water, it seems that influence of water chemistry on susceptibility to IGSCC of irradiated materials varies strongly from heat to heat, even among materials of 
similar type and irradiation history. Future work in this task will concentrate on determining effects of ECP at $<-100 \mathrm{mVSHE}$ and DO at $<0.1 \mathrm{ppm}$ on susceptibility to cracking of specimens of HP and CP heats of Type 304 SS irradiated in a BWR.
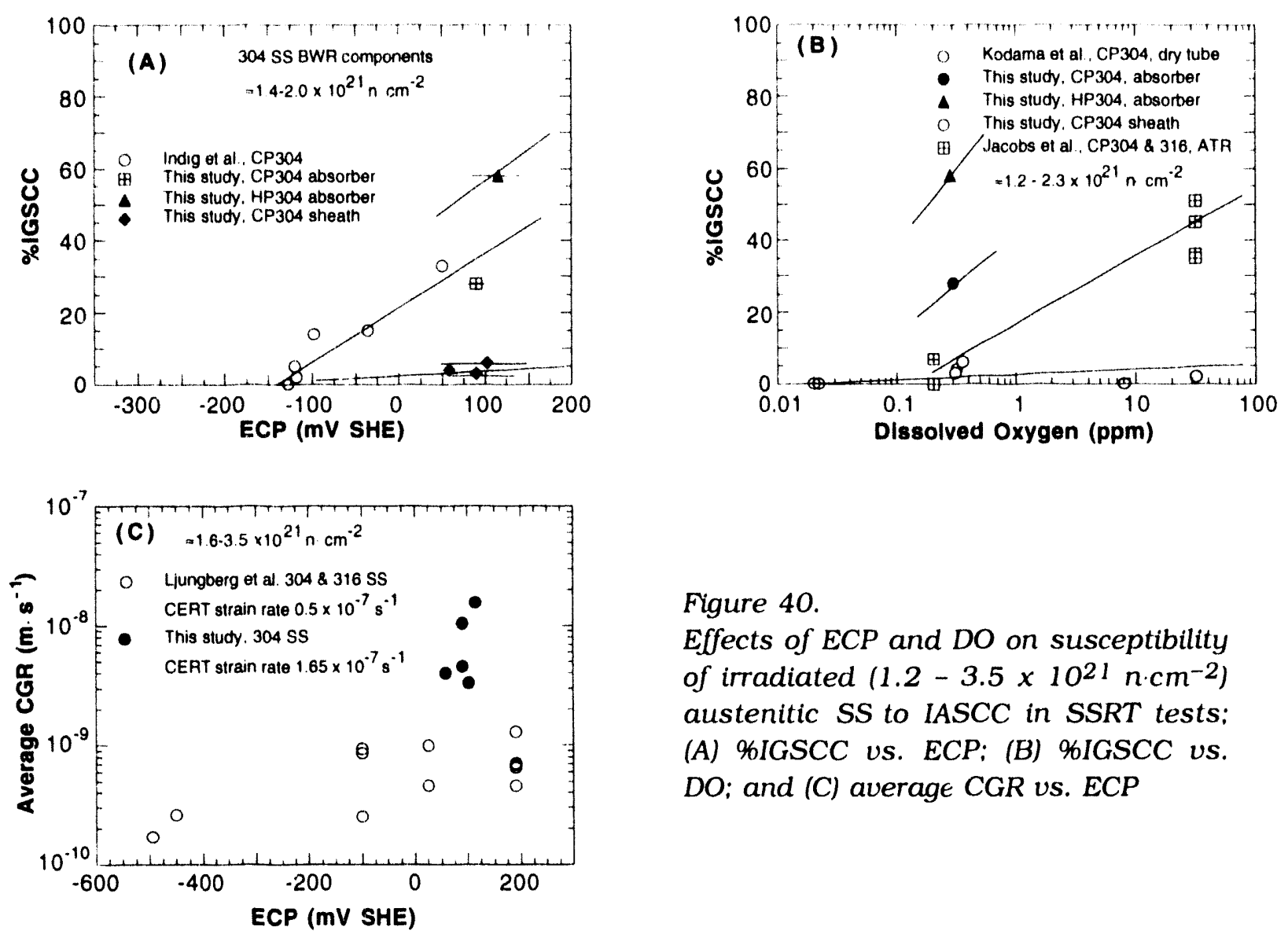

Figure 40.

Effects of ECP and DO on susceptibility of irradiated $\left(1.2-3.5 \times 10^{21} \mathrm{n} \cdot \mathrm{cm}^{-2}\right)$ austenitic SS to IASCC in SSRT tests; (A) \%IGSCC vs. ECP; (B) \%IGSCC vs. $D O ;$ and $(C)$ average CGR vs. ECP

\subsection{Irradiation of Austenitic SS Alloys in Halden Reactor (T. Karlsen, Halden Reactor Project, Halden, Norway, and H. M. Chung)}

Irradiation of SSRT and CT fracture-toughness specimens of austenitic SS in the Halden heavy-bolling-water reactor (HBWR) has been in progress. The cooperative work, jointly conducted with the OECD Halden Reactor Project in Norway, utilizes dry irradiation capsules (see Fig. 41). The reactor loop operates under a condition similar to that of a BWR; temperature and fast neutron flux $(E>1 \mathrm{MeV})$ of the specimens stacked in He-filled capsules are $\approx 288^{\circ} \mathrm{C}$ and $\approx 4-6 \times 10^{13} \mathrm{n} \cdot \mathrm{cm}^{-2} \cdot \mathrm{s}^{-1}$, respectively.

A total of 96 SSRT and 24 CT specimens, machined from 27 model alloys of austenitic SS, are being irradiated in 6 capsules, 1.e., 1 low-fluence $\left(\approx 0.5 \times 10^{21} \mathrm{n} \cdot \mathrm{cm}^{-2}, \mathrm{E}>1 \mathrm{MeV}\right)$, 2 medium-fluence $\left(\approx 1.5 \times 10^{21} \mathrm{n} \cdot \mathrm{cm}^{-2}\right)$, and 3 high-fluence $\left(\approx 3.1 \times 10^{21} \mathrm{n} \cdot \mathrm{cm}^{-2}\right)$ capsules. Four capsules were stacked vertically in the irradiation vehicle as illustrated in Fig. 41 . Each capsule filled with research-grade He contains 16 SSRT and 4 CT specimens together with 2 dummy pieces of SS to fill voids in the capsule. The specimen encapsulation and stacking sequence is shown in Fig. 42 and dimensions of the SSRT and CT specimens are given in Fig. 43. 
6 วิqе $\mathrm{L}$

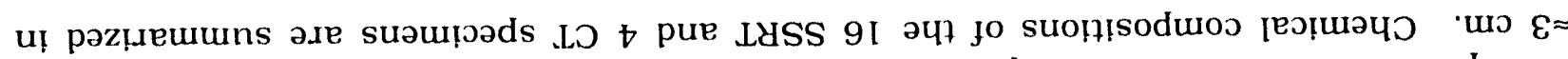

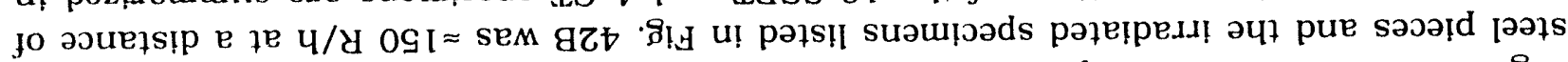

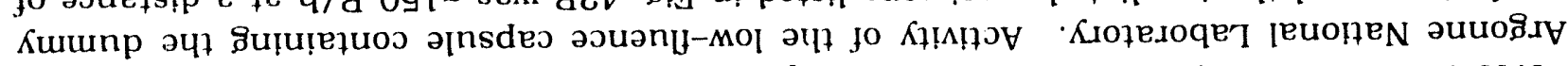

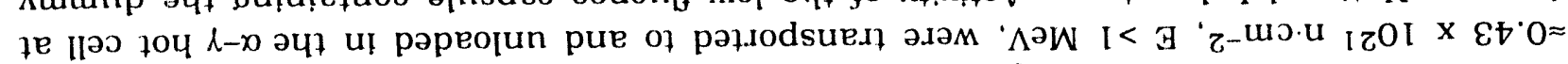

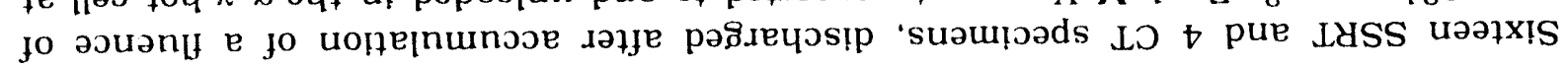

чMgH นарр⿱㇒⿴囗⿱一一)

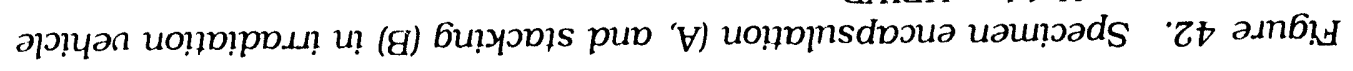
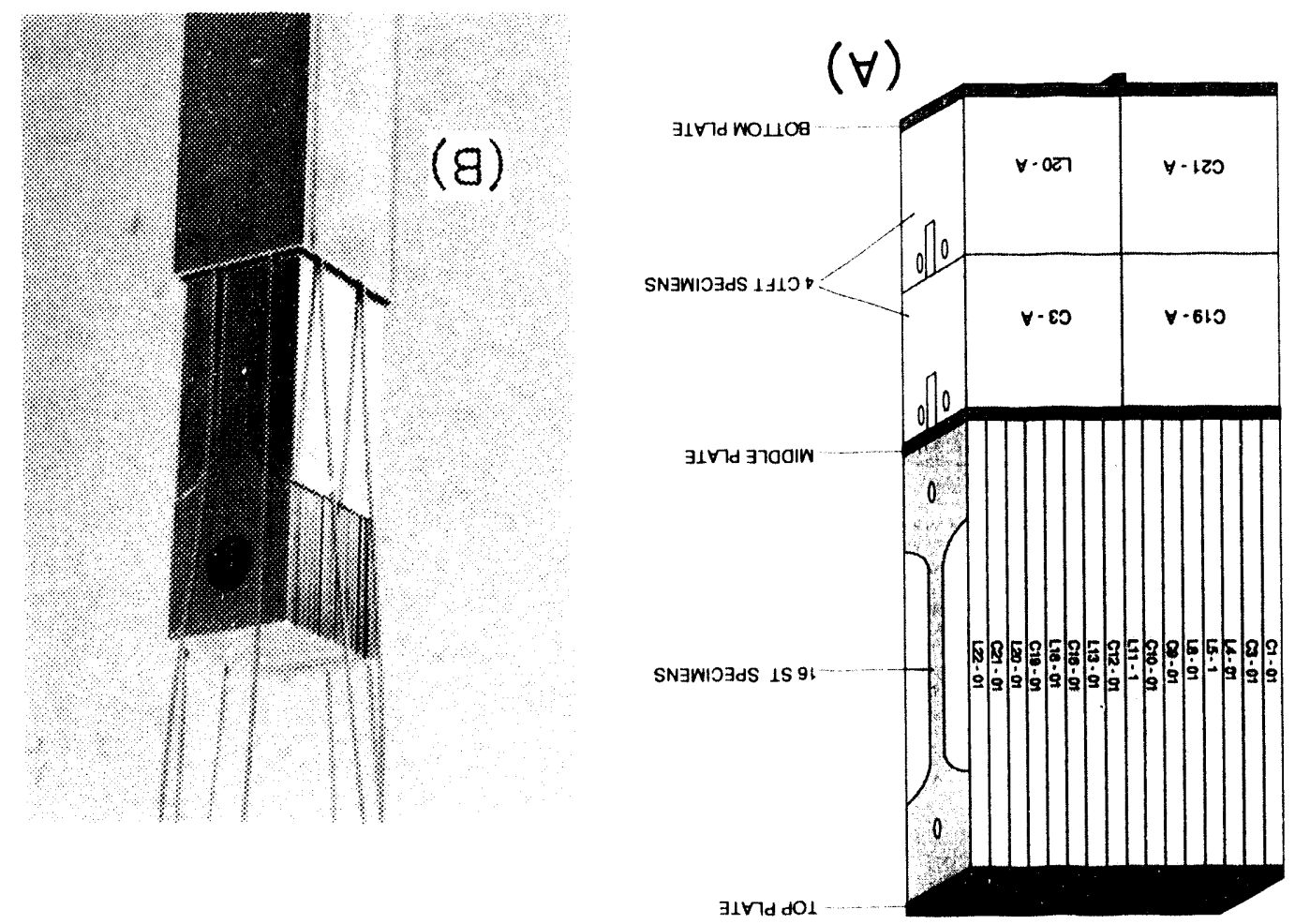

'४MяH иарірH u! 6uppol

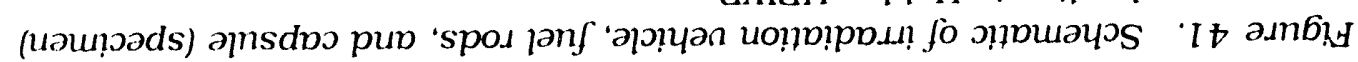
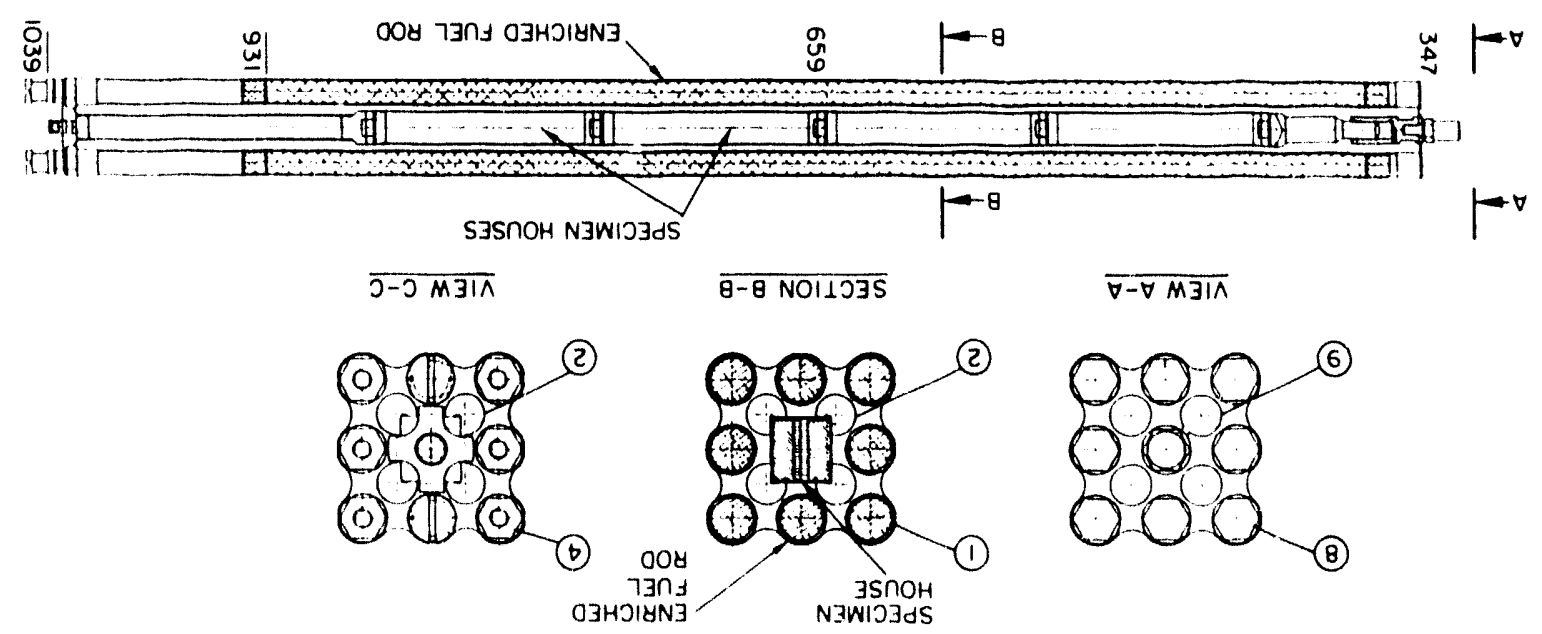

$\overline{\nabla-\nabla M 31 \Lambda}$

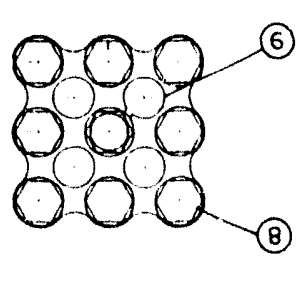




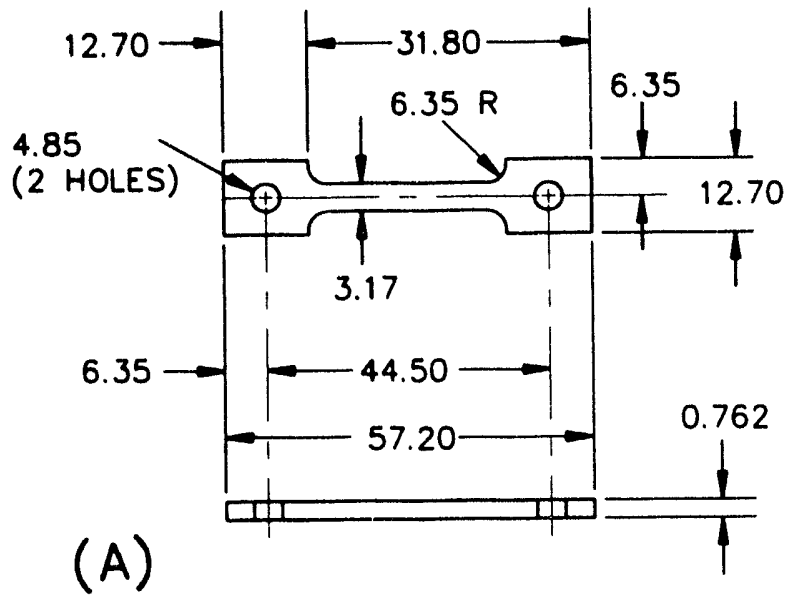

ALL DIMENSIONS IN MILLIMETER (mm)

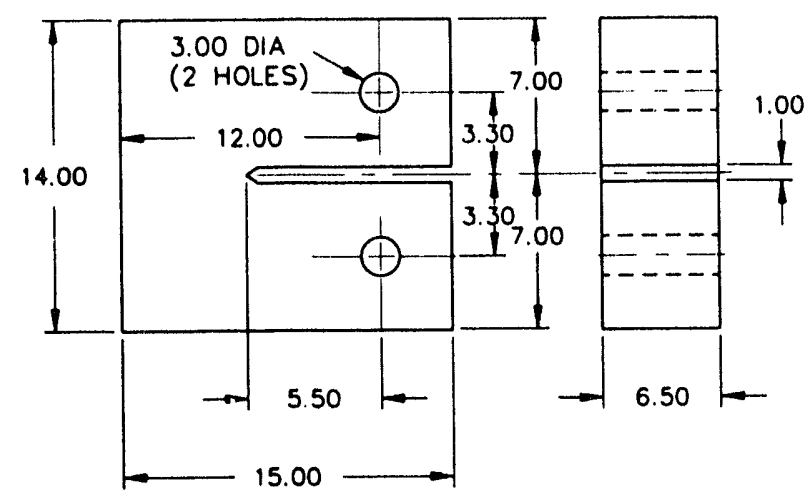

(B) all dimensions in MiLLIMETER (mm)

Figure 43. Dimensions of (A) SSRT and (B) CT specimens being irradiated in Halden HBWR

Table 9. Composition of SSRT and CT specimens of austenitic SSs irradiated to $\approx 0.43 \times 10^{21} \mathrm{n} \cdot \mathrm{cm}^{-2}(E>1 \mathrm{MeV})$ in Halden reactor

\begin{tabular}{crccccccc}
\hline Specimen & \multicolumn{10}{c}{ Composition (wt.\%) } \\
\hline ID No. & \multicolumn{1}{c}{$\mathrm{Ni}$} & $\mathrm{S} 1$ & $\mathrm{P}$ & $\mathrm{S}$ & $\mathrm{Mn}$ & $\mathrm{C}$ & $\mathrm{N}$ & $\mathrm{Cr}$ \\
\hline SSRT & & & & & & & & \\
C1-1 & 8.12 & 0.50 & 0.038 & 0.002 & 1.00 & 0.060 & 0.060 & 18.11 \\
C3-1 & 8.91 & 0.46 & 0.019 & 0.004 & 1.81 & 0.016 & 0.083 & 18.55 \\
L4-1 & 10.20 & 0.94 & 0.031 & 0.010 & 1.75 & 0.110 & 0.002 & 15.80 \\
L5-1 & 9.66 & 0.90 & 0.113 & 0.028 & 0.47 & 0.006 & 0.033 & 21.00 \\
L8-1 & 10.20 & 0.15 & 0.093 & 0.010 & 1.85 & 0.041 & 0.001 & 18.30 \\
C9-1 & 8.75 & 0.39 & 0.013 & 0.013 & 1.72 & 0.062 & 0.065 & 18.48 \\
C10-1 & 8.13 & 0.55 & 0.033 & 0.002 & 1.00 & 0.060 & 0.086 & 18.19 \\
L11-1 & 8.15 & 0.47 & 0.097 & 0.009 & 1.02 & 0.014 & 0.004 & 17.40 \\
C12-1 & 8.23 & 0.47 & 0.018 & 0.002 & 1.00 & 0.060 & 0.070 & 18.43 \\
L13-1 & 8.18 & 1.18 & 0.027 & 0.022 & 0.36 & 0.026 & 0.001 & 17.40 \\
C16-1 & 12.90 & 0.38 & 0.014 & 0.002 & 1.66 & 0.020 & 0.011 & 16.92 \\
L18-1 & 8.13 & 0.14 & 0.016 & 0.033 & 1.13 & 0.080 & 0.001 & 18.00 \\
C19-1 & 8.08 & 0.45 & 0.031 & 0.003 & 0.99 & 0.060 & 0.070 & 18.21 \\
L20-1 & 8.91 & 0.17 & 0.010 & 0.004 & 0.41 & 0.002 & 0.002 & 18.10 \\
C21-1 b & 10.24 & 0.51 & 0.034 & 0.001 & 1.19 & 0.060 & 0.020 & 16.28 \\
L22-1 c & 13.30 & 0.24 & 0.015 & 0.004 & 0.40 & 0.003 & 0.001 & 16.10 \\
CT & & & & & & & & \\
C3-A & 8.91 & 0.46 & 0.019 & 0.004 & 1.81 & 0.016 & 0.083 & 18.55 \\
C19-A & 8.08 & 0.45 & 0.031 & 0.003 & 0.99 & 0.060 & 0.070 & 18.21 \\
L20-1 & 8.91 & 0.17 & 0.010 & 0.004 & 0.41 & 0.002 & 0.002 & 18.10 \\
C21-1b & 10.24 & 0.51 & 0.034 & 0.001 & 1.19 & 0.060 & 0.020 & 16.28 \\
\hline
\end{tabular}

aLetters "C" and " $\mathrm{L}$ " denote commercial and laboratory heats, respectively.

bCommercial-purity Type $316 \mathrm{SS}, \mathrm{Mo}=2.08 \mathrm{wt} . \%$

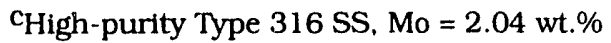




\subsection{J-R Fracture Toughness Test of Irradiated Austenltic SS (W. E. Ruther and H. M. Chung)}

The SSRT and miniature CT specimens of austenitic SSs (Fig. 43B), already received or being irradiated to higher fluences in the Halden HBWR, will be tested in a hot cell to determine the effects of irradiation damage, chemical composition, and fabrication procedures on the fracture toughness and tensile properties. Hot-cell equipment is currently avallable for high-temperature testing of irradiated SSRT specimens, but adaptation of existing equipment is now in progress for performing in-cell $\mathrm{J}-\mathrm{R}$ tests of the miniature CT specimens. The equipment has been designed to conduct CGR tests on these specimens in the future.

Loading will be done with an MTS hydraulic system operating under strain control, and crack length will be monitored by the reversing DC potential-drop method, which has been used successfully on standard 1TCT specimens for $>5$ years in this laboratory. The method is being adapted to test the miniature irradiated specimens. Such a system has been used by other investigators. 77

A schematic of $\mathrm{J}-\mathrm{R}$ equipment that is being assembled is shown in Fig. 44 . Each miniature CT specimen requires the attachment of four electrical wires: threaded holes have been provided for connecting these leads to the irradiated specimens. Small jigs have

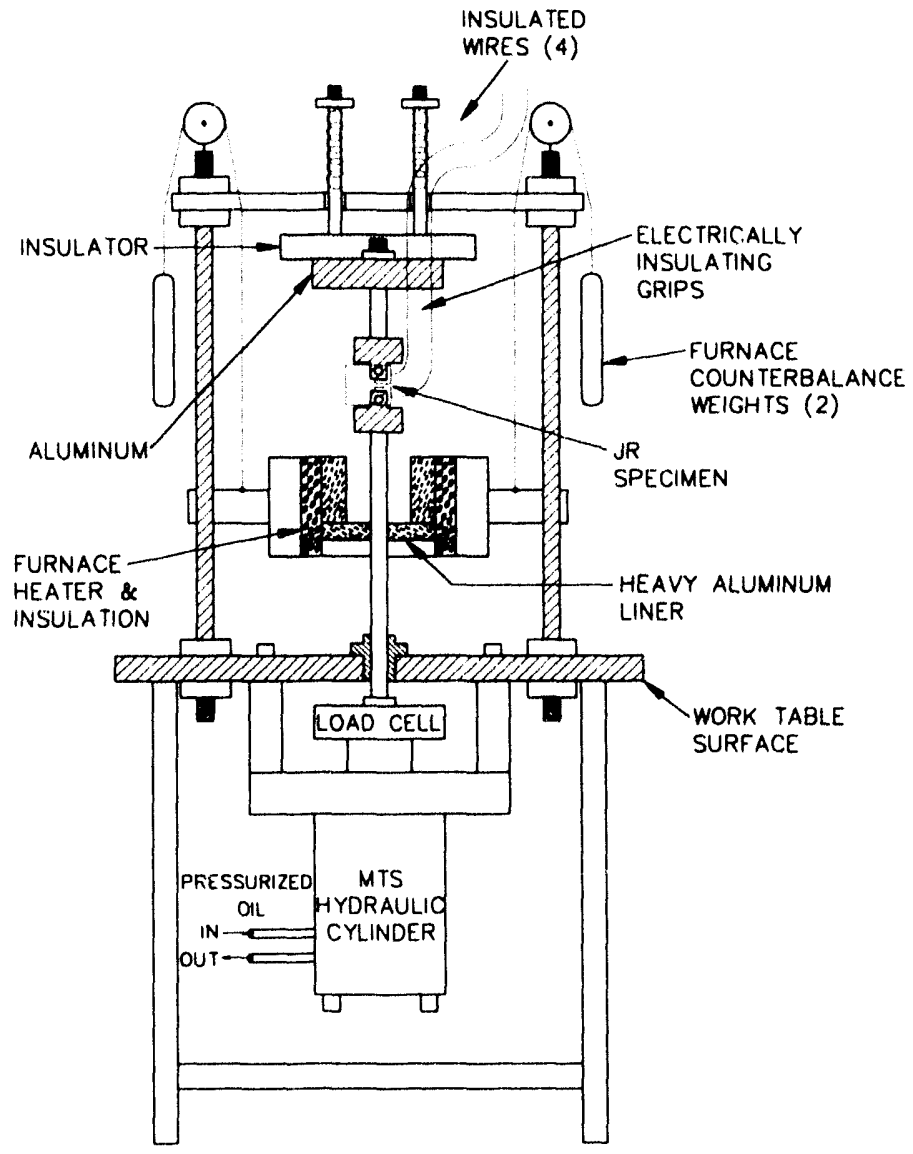

Figure 44. Schematic of $J-R$ fracture-toughness facility for tests on miniature CT specimens of austenitic SS irradiated in Halden HBWR 
been prepared and tested for holding the specimen and aligning the machine screws and holes so that a minimum of delicate handling will be iequired by hot-cell mechanical manipulators. The CT specimen is mounted vertically between mica insulated grips. The furnace and heavy-walled aluminum liner are counterbalanced so that they may be lowered for specimen installation and then raised to surround the sample and grips for hightemperature testing in air. The top and bottom of the furnace are also made of heavy aluminum and fit snugly with the liner to approximate a "black. body". condition within the furnace.

\section{Summary of Results}

\subsection{Fatigue of Ferritic Steels}

- The fatigue behavior of A 106-Gr B carbon steel and A533-Gr B low-alloy steel has been investigated in oxygenated water and in air. The results confirm the significant reduction in fatigue life and strong dependence on strain rate. For both steels, fatigue life in oxygenated water decreases with decreases in strain rate or increases in DO.

- The effects of strain rate on fatigue life saturate at some low value of strain rate, e.g., between 0.0004 and $0.001 \% / \mathrm{s}$ in oxygenated water with $\approx 0.8 \mathrm{ppm}$ DO. The actual value of saturation strain rate may vary with $D O$ and sulfur content of the steel.

- The results show that although the cyclic stress-strain and cyclic-hardening behavior of carbon and low-atuy steels are distinctly different, there is little or no difference in susceptibility to environmental degradation of fatigue life of these steels, when sulfur levels are comparable. The A106-Gr B carbon steel exhibits pronounced dynamic strain-aging, whereas strain aging effects are modest in the A533-Gr B low-alloy steel.

- A detailed examination of the gage surfaces of the specimens was conducted to investigate the role of high-temperature oxygenated water in fatigue crack nucleation. The results suggest that oxygenated water has no effect on nucleation of cracks. All specimens tested in water showed surface micropitting due to either corrosion of the material or selective dissolution of $\mathrm{MnS}$ or other inclusions. However, there is no indication that a fatigue crack nucleated at any of the surface micropits. Examination of the fatigue specimens indicates that irrespective of environment, cracks in carbon and low-alloy steels nucleate along slip bands, carbide particles, or at ferrite/pearlite phase boundaries.

\subsection{Environmentally Assisted Cracking of Cast SS}

- Crack growth rate (CGR) tests were conducted on fracture-mechanics specimens of as-received and thermally aged $\mathrm{CF}-8 \mathrm{M}$ cast SS in air to provide baseline information for comparison with results for wrought SSs in air in Section XI of the ASME Code and in oxygenated water. The results indicated that long-term thermal aging had no effect on CGRs of $\mathrm{CF}-8 \mathrm{M}$ SS in air. The experimental data were consistent with predictions from the ASME Code at rates of $\geq 5 \times 10^{-10} \mathrm{~m} \cdot \mathrm{s}^{-1}$, but were below Code predictions by one order of magnitude at lower rates. 
- Additional crack growth tests have been conducted on fracture-mechanics specimens of $\mathrm{CF}-8$ and $\mathrm{CF}-8 \mathrm{M}$ grades of cast SS in the as-received and thermally aged conditions to characterize material, loading, and environmental conditions that can produce environmentally assisted cracking in these steels.

- CGRs of thermally aged CF-8M specimens (with carbon and ferrite contents of 0.065 wt. $\%$ and $27.8 \%$, respectively) show larger environmental enhancement than asreceived and thermally aged $\mathrm{CF}-8$ specimens (with carbon and ferrite contents of 0.063 wt. $\%$ and $23.4 \%$, respectively) in HP oxygenated water at load ratios between 0.3 and 0.95 .

- The dependence of the CGR of thermally aged CF-8 SS on DO concentration 10.002 to $8 \mathrm{ppm})$ and electrochemical potential of Type 304 SS (-565 to $250 \mathrm{mVSHE})$ in HP water was determined at a load ratio of 0.95 , a rise time of $12 \mathrm{~s}$, and a $\mathrm{K}_{\max }$ of 35-38 $\mathrm{MPa} \cdot \mathrm{m}^{1 / 2}$. The CGRs increase rapidly with $\mathrm{DO}$ concentration over a relatively narrow range of $\approx 0.05-0.2 \mathrm{ppm}$ and become virtually independent of DO concentration at values $>0.2 \mathrm{ppm}$. The CGRs at high DO concentrations indicate that the air curve is frequently nonconservative, but the data are bounded by the modified correlations for wrought SSs in water at $289^{\circ} \mathrm{C}$.

- Metallographic evaluation of the specimens after the experiments indicated that the mode of cracking in the $\mathrm{CF}-8 \mathrm{M}$ specimens in air was transgranular and that the crack path in all specimens in water favored the ferrite/austenite phase boundaries in the materials.

\subsection{Irradiation-Assisted Stress Corrosion Cracking of Type 304 SS}

- The role of minor impurity and trace elements in austenitic SSs, not quantified in the ASTM specifications, in IASCC was examined. Surprisingly, the susceptibility to IGSCC of specimens obtained from irradiated BWR components correlates well with the grainboundary concentrations of $\mathrm{F}$ and $\mathrm{V}$. Fluorine apparently originates from welding electrodes or fluorspar, a compound frequently used as flux material by many producers of iron and steels (or from recycling of $\mathrm{F}$-containing steel scrap), whereas $\mathrm{V}$ originates from ferrovanadium, a strengthening addition used extensively by most steel makers. Fluorine seems to be trapped by certain types of precipitates, indicating an important role of precipitation in austenitic SSs.

- A comparison of preliminary data in this study and those reported in literature indicates that, unlike the dependence of IGSCC of thermally sensitized materials on ECP or DO concentration in water, the influence of water chemistry on susceptibility to IGSCC of irradiated materials varies strongly from heat to heat, even among materials of a similar type and irradiation history.

- Sixteen SSRT and 4 CT specimens of austenitic SS alloys were discharged from the Halden HBWR after a fluence of $\approx 0.43 \times 10^{21} \mathrm{n} \cdot \mathrm{cm}^{-2}(\mathrm{E}>1 \mathrm{MeV})$. An apparatus is being assembled for $J-R$ fracture-toughness tests of the specimens. Specimen loading is accomplished by means of an MTS hydraulic system that operates under strain control. Crack length will be monitored by the reversing DC potential-drop method. 


\section{References}

1. K. Lida, A Review of Fatigue Failures in LWR Plants in Japan, Nucl. Eng. Des. 138. 297-312 (1992).

2. ASME Boiler and Pressure Vessel Code Section III - Rules for Construction of Nuclear Power Plant Components. The American Society of Mechanical Engineers, 345 East 47 th Street, New York, NY 10017.

3. Criteria of Section III of the ASME Boiler and Pressure Vessel Code for Nuclear Vessels, The American Society of Mechanical Engineers, United Engineering Center, New York. Library of Congress Catalog No. 56-3934 (1989).

4. Tentative Structural Design Basis for Reactor Pressure Vessels and Directly Associated Components (Pressurized. Water Cooled Systems), PB 151987, U.S. Dept. of Commerce, Office of Technical Service, 1 Dec. 1958 Revision.

5. D. A. Hale, S. A. Wilson, E. Kiss, and A. J. Gianuzzi, Low Cycle Fatigue Evaluation of Primary Piping Materials in a BWR Environment, GEAP-20244, U.S. Nuclear Regulatory Commission (Sept. 1977).

6. D. A. Hale, S. A. Wilson, J. N. Kass, and E. Kiss, Low Cycle Fatigue Behavior of Commercial Piping Materials in a BWR Environment, J. Eng. Mater. Technol. 103. 15-25 (1981).

7. S. Ranganath, J. N. Kass, and J. D. Heald, Fatigue Behavior of Carbon Steel Components in High-Temperature Water Environments, in Low-Cycle Fatigue and Life Prediction, ASTM STP 770, C. Amzallag, B. N. Leis, and P. Rabbe, eds., American Society for Testing and Materials, Philadelphia, pp. 436-459 (1982).

8. S. Ranganath, J. N. Kass, and J. D. Heald, Fatigue Behavior of Carbon Steel Components in High-Temperature Water Environments, in BWR Environmental Cracking Margins for Carbon Steel Piping, EPRI NP-2406, Electric Power Research Institute, Palo Alto, CA, Appendix 3 (May 1982).

9. J. B. Terrell, Fatigue Life Characterization of Smooth and Notched Piping Steel Specimens in $288^{\circ} \mathrm{C}$ Air Environments, NUREG/CR-5013, MEA-2232 (May 1988).

10. J. B. Terrell, Fatigue Strength of Smooth and Notched Specimens of ASME SA 106-B Steel in PWR Environments, NUREG/CR-5136, MEA-2289 (Sept. 1988).

11. J. B. Terrell, Effect of Cyclic Frequency on the Fatigue Life of ASME SA-106-B Piping Steel in PWR Environments, J. Mater. Eng. 10,193-203 (1988).

12. P. D. Hicks, in Environmentally Assisted Cracking in Light Water Reactors: Semiannual Report October 1990-March 1991. NUREG/CR-4667 Vol. 12, ANL-91/24, pp. 3-18 (Aug. 1991).

13. P. D. Hicks and W. J. Shack, Fatigue of Ferritic Steels, in Environmentally Assisted Cracking in Light Water Reactors, Semiannual Report, April-September 1991 , NUREG/CR-4667 Vol. 13, ANL-92/6, pp. 3-8 (March 1992).

14. O. K. Chopra, W. F. Michaud, and W. J. Shack, in Environmentally Assisted Cracking in Light Water Reactors, Semiannual Report, October 1992-March 1993, NUREG/CR4667 Vol. 16. ANL-93/27, pp. 3-19 (Sept. 1993).

15. M. Higuchi and K. Iida, Fatigue Strength Correction Factors for Carbon and Low-Alloy Steels in Oxygen-Containing High-Temperature Water, Nucl. Eng. Des. 129, 293-306 (1991). 
16. K. IIda, H. Kobayashi, and M. Higuchi, Predictive Method of Low Cycle Fatigue Life of Carbon and Low Alloy Steels in High Temperature Water Environments, NUREG/CP0067, MEA-2090, Vol. 2 (April 1986).

17. N. Nagata, S. Sato, and Y. Katada, Low-Cycle Fatigue Behavior of Low-Alloy Steels in High-Temperature Pressurized Water, in Transactions 10th Int. Conf. on Structuril Mechanics in Reactor Technology, Vol. F, A. H. Hadjian, ed., American Association for Structural Mechanics in Reactor Technology. Anaheim, CA (1989).

18. S. Majumdar, O. K. Chopra, and W. J. Shack, Interim Fatigue Design Curves for Carbon, Low-Alloy, and Austenitic Stainless Steels in LWR Environments, NUREG/CR-5999, ANL-93/3 (April 1993).

19. T. A. Prater and L. F. Coffin. The Use of Notched Compact-Type Specimens for Crack Initiation Design Rules in High-Temperature Water Environments, in Corrosion Fatigue: Mechanics Metallurgy, Electrochemistry, and Engineering, ASTM STP 801, T. W. Crooker and B. N. Leis, eds., American Society for Testing and Materials, Philadelphia, pp. 423-444 (1983).

20. T. A. Prater and L. F. Coffin, Notch Fatigue Crack Initiation in High Temperature Water Environments: Experiments and Life Prediction, J. of Pressure Vessel Technol.. Trans. ASME, 109, 124-134 (1987).

21. M. O. Speidel and R. M. Magdowski. Stress Corrosion Cracking of Nuclear Reactor Pressure Vessel Steel in Water: Crack Initiation versus Crack Growth, Corrosion 88. Paper No. 283, St. Louis, MO, (March 1988).

22. F. P. Ford and P. L. Andresen, Stress Corrosion Cracking of Low-Alloy Pressure Vessel Steel in $288^{\circ} \mathrm{C}$ Water, in Proc. 3rd Int. Atomic Energy Agency Specialists' Meeting on Subcritical Crack Growth, NUREG/CP-0112, Vol. 1, pp. 37-56 (Aug. 1990).

23. P. M. Scott and D. R. Tice, Stress Corrosion in Low-Alloy Steels, Nucl. Eng. Des. 119. 399-413 (1990).

24. W. H. Cullen, The Effects of Sulfur Chemistry and Load Ratio on Fatigue Crack Growth Rates in LWR Environments, in Proc. 2nd Int. Atomic Energy Agency Specialists' Meeting on Subcritical Crack Growth, NUREG/CP-0067, MEA-2090, Vol. 2, pp. 339-355 (April 1986).

25. J. D. Atkinson, J. H. Bulloch, and J. E. Forrest, TA Fractographic Study of Fatigue Cracks Produced in A533B Pressure Vessel Steel Exposed to Simulated PWR Primary Water Environments, in Proc. 2nd Int. Atomic Energy Agency Specialists' Meeting on Subcritical Crack Growth, NUREG/CP-0067, MEA-2090, Vol. 2, pp. 269-290 (April 1986).

26. W. A. Van Der Sluys and D. S. DeMiglio, An Investigation of Fatigue Crack Growth in SA508-2 in a $288^{\circ} \mathrm{C}$ PWR Environment by a Constant $\triangle K$ Test Method, in Proc. Int. Atomic Energy Agency Specialists' Meeting on Subcritical Crack Growth, NUREG/CP-0044, MEA-2014, Vol. 1, pp. 44-64 (May 1983).

27. J. H. Bulloch, A Review of the Fatigue Crack Extension Behavior of Ferritic Pressur' Vessel Materials in Pressurized Water Reactor Environments, Res. Mechanica 26. 95-172 (1989).

28. T. F. Kassner, W. J. Shack, W. E. Ruther, and J. H. Park, in Environmentally Assisted Cracking in Light Water Reactors: Semiannual Report, April-September 1990, NUREG/CR-4667 Vol. 11, ANL-91/9, pp. 2-9 (May 1991).

29. D. D. Macdonald, S. Smialowska, and S. Pednekar, The General and Localized Corrosion of Carbon and Low-Alloy Steels in Oxygenated High-Temperature Water, NP-2853 (Feb. 1983). 
30. J. Kuniya, H. Anzai, and I. Masaoka, Effect of MnS Inclusions on Stress Corrosion Cracking in Low-Alloy Steels, Corrosion 48(5), 419-425 (1992).

31. O. K. Chopra and G. Ayrault, Aging Degradation of Cast Stainless Steel: Status and Program, Nucl. Eng. Des. 86, 69-77 (1985).

32. H. M. Chung and O. K. Chopra, Microstructures of Cast-Duplex Stainless Steels After Long-Term Aging, in Proc. 2nd Int. Symp. on Environmental Degradation of Materials in Nuclear Power Systems - Water Reactors. Monterey, CA, The American Nuclear Society, La Grange Park. IL, pp. 287-292 (1986).

33. H. M. Chung and O. K. Chopra, Long-Term Aging Embrittlement of Cast Austenitic Stainless Sleels - Mechanisms and Kinetics, in Properties of Stainless Steels in Elevated Temperature Service, M. Prager, ed., MPC-Vol. 26, PVP Vol. 132. American Society of Mechanical Engineers, New York, pp. 17-34 (1988).

34. H. M. Chung and O. K. Chopra, Kinetics And Mechanisms of Thermal Aging Embrittlement of Duplex Stainless Steels, in Proc. 3rd Int. Symp. on Environmental Degradation of Materials in Nuclear Power Systems - Water Reactors, Traverse City, MI, G. J. Theus and J. R. Weeks, eds., The Metallurgical Society, pp. 359-370 (1988).

35. H. M. Chung. Thermal Aging of Decommissioned Reactor Cast Stainless Steel Components and Methodology for Life Prediction. Proc. 1989 ASME Pressure Vessel and Piping Conf., Honolulu, T. V. Narayana, et. al., eds., PVP Vol. 171, pp. 111-115 (1989).

36. H. M. Chung, Spinodal-like Decomposition of Austenite in Long-Term Aged Duplex Stainless Steel, Physical Metallurgy of Controlled Expansion Invar-Type Alloys, K. C. Russell and D. F. Smith, eds., The Minerals, Metals, and Materials Society, Warrendale, PA, pp. 129-141 (1990).

37. H. M. Chung and T. R. Leax, Embrittlement of Laboratory-and Reactor-Aged CF-3, CF8, and CF-8M Duplex Stainless Steels, Mater. Sci. and Technol. 6, 249-262 (1990).

38. H. M. Chung and O. K. Chopra, Accelerated Aging Embrittlement of Cast Duplex Stainless Steel - Activation Energy for Extrapolation, Proc. 4th Int. Symp. on Environmental Degradation of Materials in Nuclear Power Systems - Water Reactors, D. Cubicciotti, ed., National Association of Corrosion Engineers, Houston, pp. 3-47 to 3-65 (1990).

39. H. M. Chung. Evaluation and Diagnosis of Aging of Cast Stainless Steel Components, Proc. ASME Pressure Vessel and Piping Conf., PVP Vol. 208, American Society of Mechanical Engineers, New York, pp. $121-136$ (1991).

40. H. M. Chung, Aging and Life Prediction of Cast Duplex Stainless Steel Components, Int. J. Pres. Ves. \& Piping 50, 179-213 (1992).

41. W. F. Michaud, P. T. Toben, W. K. Soppet, and O. K. Chopra, Tensile-Property Characterization of Thermally Aged Cast Stainless Steels, NUREG/CR-6142, ANL93/35 (Feb. 1994).

42. O. K. Chopra and H. M. Chung, Aging of Cast Duplex Stainless Steels in LWR Systems, Nucl. Eng. Des. 89, 305-318 (1985).

43. O. K. Chopra and H. M. Chung, Effects of Low Temperature Aging on the Mechanical Properties of Cast Stainless Steels, in Properties of Stainless Steels in Elevated Temperature Service, M. Prager, ed., MPC-Vol. 26, PVP Vol. 132, American Society of Mechanical Engineers, New York, pp. 79-105 (1988). 
44. O. K. Chopra and H. M. Chung, Aging Degradation of Cast Stainless Steels: Elfects on Mechanical Properties, in Proc. 3rd Int. Symp. on Environmental Degradation of Materials in Nuclear Power Systems - Water Reactors, Traverse City, MI, G. J. Theus and J. R. Weeks, eds.. The Metallurgical Society, pp. 737-748 (1988).

45. O. K. Chopra and H. M. Chung, Embrittlement of Cast Stainless Steels in LWR Systems, Proc. 15th MPA-Seminar on Safety and Reliability of Plant Technology. Vol. 1, pp. 13.1-13.23 (1989).

46. O. K. Chopra, Thermal Aging of Cast Stainless Steels: Mechanisms and Predictions, Fatigue, Degradation, and Fractures, W. H. Bamford. C. Becht IV. S. Bhandari. J. D. Gilman, L. A. James, and M. Prager, eds., PVP Vol. 195, The American Society of Mechanical Engineers, New York, pp. 193-214 (1990).

47. O. K. Chopra, Thermal Aging of Cast Stainless Steels in LWR Systems: Estimation of Mechanical-Properties, Nuclear Plant Systems/Components Aging Management and Life Extension, American Society of Mechanical Engineers, PVP Vol. 228. pp. 79-92 (1992).

48. O. K. Chopra, Prediction of Aging Degradation of Cast Stainless Steel Components in LWR Systems, in Proc. Aging Research Information Conf., NUREG/CP-0122 Vol. 2, pp. 324-340 (1992).

49. O. K. Chopra and W. J. Shack, Evaluation of Aging Degradation of Structural Components, in Proc. Aging Research Information Conf., NUREG/CP-0122 Vol. 2, pp. 369-386 (1992).

50. O. K. Chopra, Long-Term Embrittlement of Cast Duplex Stainless Steels in LWR Systems: Semiannual Report, October 1990 - March 1991, NUREG/CR-4744 Vol. 6. No 1, ANL-91/22 (Aug. 1992).

51. O. K. Chopra, Long-Term Embrittlement of Cast Duplex Stainless Steels in LWR Systems: Semiannual Report, April - September 1991. NUREG/CR-4744 Vol. 6. No 2, ANL $-92 / 32$ (Nov. 1992).

52. O. K. Chopra, Long-Term Embrittlement of Cast Duplex Stainless Steels in LWR Systems: Semiannual Report, October 1991 - March 1992, NUREG/CR-4744 Vol. 7. No 1, ANL-92/42. (May 1993).

53. W. E. Ruther, O. K. Chopra, and T. F. Kassner, in Environmentally Assisted Cracking in Light Water Reactors: Semiannual Report, April - September 1992, NUREG/CR-4667 Vol. 15, ANL-93/2, pp. 21-28 (June 1993).

54. W. E. Ruther, O. K. Chopra, and T. F. Kassner, in Environmentally Assisted Cracking in Light Water Reactors: Semiannual Report, October 1992 - March 1993, NUREG/CR4667 Vol. 16, ANL-93/27, pp. 19-27 (Sept. 1993).

55. W. E. Ruther, J. Y. Park, T. F. Kassner, and W. K. Soppet, in Environmentally Assisted Cracking in Light Water Reactors: Semiannual Report, October 1988 - March 1989 , NUREG/CR-4667 Vol. 8. ANL-90/4, pp. 2-5 (June 1990).

56. J. Y. Park and W. J. Shack, in Environmentally Assisted Cracking in Light Water Reactors: Semiannual Report, April 1989 - September 1989, NUREG/CR-4667 Vol. 9. ANL-90/48, pp. 3-6 (March 1991).

57. W. J. Shack, in Environmentally Assisted Cracking in Light Water Reactors: Semiannual Report, October 1990 - March 1991. NUREG/CR-4667 Vol. 12, ANL-91/24, pp. 30-37 (Aug. 1991).

58. W. J. Shack and T. F. Kassner, Review of Environmental Effects on Fatigue Crack Growth of Austenitic Stainless Steels, NUREG/CR-6176, ANL-94/1 (April 1994). 
59. H. M. Chung, W. E. Ruther, J. E. Sanecki, and A. G. Hins, In Environmentally Assisted Cracking in Light Water Reactors: Semiannual Report October 1992-March 1993. NUREG/CR-4667 Vol. 16, ANL-93/27. Argonne National Laboratory, pp. 27-40 (Sept. 1993).

60. H. M. Chung, W. E. Ruther, J. E. Saneck1, and T. F. Kassner, Grain-Boundary Microchemistry and Intergranular Cracking of Irradiated Austenitic Stainless Steels, in Proc. 6th Intl. Symp. on Environmental Degradation of Materials in Nuclear Power Systems - Water Reactors, R. E. Gold and E. P. Simonen, eds., The Minerals, Metals, and Materials Soctety, Warrendale, PA, pp. 511-519 (1993).

61. F. Garzarolli, P. Dewes, R. Hahn, and J. L. Nelson, Deformability of High-Purity Stainless Steels and Ni-Base Alloys in the Core of a PWR, lbid., pp. 607-613 (1993).

62. F. Garzarolli, D. Alter. P. Dewes, and J. L. Nelson, Deformability of Austenitic Stainless Steels and Ni-Base Alloys in the Core of a Boiling and Pressurized Water Reactor, Proc. 3rd Int. Symp. Environmental Degradation of Materials in Nuclear Power Systems Water Reactors, G. J. Theus and J. R. Weeks, eds., The Metallurgical Society, Warrendale, PA, pp. 657-664 (1988).

63. H. M. Chung, W. E. Ruther, J. E. Saneck1, A. G. Hins, and T. F. Kassner, Stress Corrosion Cracking Susceptibility of Irradiated Type 304 Stainless Steels, Effects of Radiation on Materials: 16th Int. Symp.. ASTM STP 1175, A. S. Kumar, D. S. Gelles, R. K. Nanstad, and T. A. Little, eds., American Society for Testing and Materials, Philadelphia. pp. 851-869 (1993).

64. H. L. Marcus and P. W. Palmberg, TMS-AIME, 245, 1664 (1969).

65. A. Joshi and D. F. Stein, Corrosion, 28, 321-329 (1972).

66. H. E. Bishop and J. C. Riviere, Acta Met. 18, 813-817 (1970).

67. A. Kimura, D. S. Gelles, D. R. Baer, and R. H. Jones, Irradiation Induced Changes in the Grain Boundary Chemistry in Manganese-Stabilized Reduced Activation Martensitic Steels, Annual Progress Report for Fusion Year 1989, Japan Monbusho-U.S. DOE Collaboration Program, pp. 155-162 (June 1990).

68. H. M. Chung, W. E. Ruther, and J. E. Sanecki, in Environmentally Assisted Cracking in Light Water Reactors: Semiannual Report April-September 1990, NUREG/CR-4667 Vol. 11, ANL-91/9, Argonne National Laboratory, p. 13 (May 1991).

69. I. Aho-Mantila and H. Hanninen, Electrochemical Methods to Estimate IASCC Susceptibility of Stainless Steels, Proc. Intl. Conf. on Materials for Nuclear Core Applications, Oct. 27-29, 1987, Bristol, UK.

70. M. Enomoto, C. L. White, and H. I. Aaronson, Met. Trans. A, 19A, 1807-1818 (1988).

71. D. J. Nettleship and R. K. Wild, The Effect of Neutron Irradiation on Segregation to Grain Boundaries in Nimonic PE16, Effects of Radiation on Materials: 15th Int. Symp., ASTM STP 1125, R. E. Stoller, A. S. Kumar, and D. S. Gelles, eds., American Society for Testing and Materials, Philadelphia, pp. 645-666 (1992).

72. A. J. Jacobs. The Relationship of Grain Boundary Composition in Irradiated Type 304 SS to Neutron Fluence and IASCC, Effects of Radiation on Materials: 16th Int. Symp., ASTM STP 1175, A. S. Kumar, D. S. Gelles, R. K. Nanstad, and T. A. Little, eds., American Society for Testing and Materials, Philadelphia, pp. 902-918 (1993). 
73. A. J. Jacobs, G. P. Wozaldo, K. Nakata, T. Yoshida, and I. Masaoka, Radiation Effects on the Stress Corrosion and Other Selected Properties of Type-304 and Type-316 Stainless Steels, Proc. 3rd Int. Symp. Environmental Degradation of Materials in Nuclear Power Systems - Water Reactors, G. J. Theus and J. R. Weeks, eds., The Metallurgical Society, Warrendale, PA, pp. 673-681 (1988).

74. M. E. Indig, J. L. Nelson, and G. P. Wozaldo, Investigation of the Protection Potential Against IASCC. Proc. 5th Int. Symp. Environmental Degradation of Materials in Nuclear Power Systems - Water Reactors, D. Cublcciotti, E. P. Simonen, and R. Gold, eds., American Nuclear Society. La Grange Park, IL. pp. 657-664 (1992).

75. M. Kodama, S. Nishimura, J. Morisawa, S. Shima, S. Suzuki, and M. Yamamoto, Effects of Fluence and Dissolved Oxygen on IASCC in Austenitic Stainless Steels, ibid., pp. 948-954 (1992).

76. A. Jenssen and L. G. Ljunberg, Irradiation Assisted Stress Corrosion Cracking of Stainless Alloys in BWR Normal Water Chemistry and Hydrogen Water Chemistry. in Proc. 6th Intl. Symp. on Environmental Degradation of Materials in Nuclear Power Systems Water Reactors, R. E. Gold and E. P. Simonen, eds., The Minerals, Metals, and Materials Society, Warrendale, PA, pp. 547-553 (1993).

77. E. M Hackett, M. T. Kirk, and R. A. Hays, An Evaluation of J-R Curve Testing of Nuclear Piping Materials Using the Direct Current Potential Drop Technique, NUREG/CR-4540 (July 1993). 


\section{Distribution for NUREG/CR-4667, Vol. 17 (ANL-94/16)}

Internal

W. J. Shack (45)

TIS Files

External

NRC, for distribution per R5

Libraries

ANL-E (2)

ANL-W

Manager, Chicago Field Office, DOE

Energy Technology Division Review Committee:

H. K. Birnbaum, University of Illinots, Urbana

R. C. Buchanan, University of Cincinnati. Cincinnati

M. S. Dresselhaus, Massachusetts Institute of Technology, Cambridge, MA

B. G. Jones, University of Illinois, Urbana

C.-Y. Li, Cornell University, Ithaca, NY

S. N. Liu, Fremont, CA

R. E. Smith, SciTech, Inc., Morrisville, NC

P. L. Andresen. General Electric Corporate Research and Development, Schenectady, NY

R. G. Ballinger, Massachusetts Institute of Technology, Cambridge, MA

W. H. Bamford, Structural Materials Engineering, Westinghouse Electric Corp., Pittsburgh

S. M. Bruemmer, Battelle Pacific Northwest Laboratory

H. S. Chung, Korea Atomic Energy Research Insitiute, Daejeon, Korea

G. Cragnolino, Southwest Research Inst., San Antonio, TX

W. H. Cullen, Materials Engineering Assoc., Inc., Lanham, MD

R. Duncan, ABB CE Nuclear Power, Windsor, CT

E. D. Eason, Modeling and Computing Services, Newark, CA

M. Fox, APTECH, Tucson, AZ

D. G. Franklin, Bettis Atomic Power Laboratory

Y. S. Garud, S. Levy, Inc., Campbell, CA

F. Garzarolli, KWU, Erlangen, Germany

J. Gilman, Electric Power Research Inst., Palo Alto, CA

B. M. Gordon, General Electric Co., San Jose, CA

J. W. Halley, U. Minnesota, Minneapolis

H. E. Hanninen, Technical Research Centre of Finland, Espoo

D. Harrison, USDOE, Germantown, MD

J. Hickling, CML Capcis March Ltd., Erlangen-Tennonlohe, Germany

C. Hoffmann, ABB CE Nuclear Power, Windsor, CT 
M. E. Indig, General Electric Co., Pleasanton, CA

H. S. Isaacs, Brookhaven National Laboratory

A. Jacobs, General Electric Co., San Jose, CA

L. James, Bettis Atomic Power Laboratory

C. Jansson, Vattenfall Energisystem, Vallingby, Sweden

R. H. Jones, Battelle Pacific Northwest Laboratory

R. L. Jones, Electric Power Research Institute, Palo Alto, CA

T. Karlsen, OECD Halden Reactor Project, Halden, Norway

C. Kim, Westinghouse Electric Corp., Pittsburgh

L. LJungberg, ASEA-ATOM, Vasteras, Sweden

C. D. Lundin, U. Tennessee, Knoxville

D. D. Macdonald, Pennsylvania State University, University Park

T. R. Mager, Westinghouse Electric Corp.. Pittsburgh

R. D. McCright, Lawrence Livermore National Laboratory

A. R. Mcllree, Electric Power Research Institute, Palo Alto, CA

H. Metha, General Electric Co., San Jose, CA

D. Morgan, Pennsylvania Power and Light Co.. Allentown, PA

J. L. Nelson, Electric Power Research Inst., Palo Alto, CA

D. H. Njo, Swiss Federal Nuclear Safety Inspectorate, Villigen, Switzerland

M. Prager, Materials Properties Council, New York, NY

S. Ranganath, General Electric Co., San Jose, CA

P. M. Scott, Framatome, Paris, France

J. Sedriks, Office of Naval Research, Arlington, VA

C. Shepherd, AEA Technology-Harwell Labs., Didcot, Oxon, UK

S. Smialowska, Ohio State University, Columbus

H. D. Solomon, General Electric Corporate Research and Development, Schenectady, NY

M. O. Speidel, Swiss Federal Institute of Technology, Zurich, Switzerland

D. M. Stevens, Lynchburg Research Center, Babcock \& Wilcox Co.. Lynchburg, VA

W. A. Van Der Sluys, Research \& Development Division, Babcock \& Wilcox Co., Alliance, $\mathrm{OH}$

J. C. Van Duysen, Electricite de France-Research and Development Centre de Renardieres, Moret-Sur-Loing. France

E. Venerus, Knolls Atomic Power Laboratory

C. Vitanza, OECD Halden Reactor Project, Halden, Norway

J. R. Weeks, Brookhaven National Laboratory

D. Winkel, Teleco Oil Field Services, Meriden, CT

S. Yukawa, Boulder, CO 

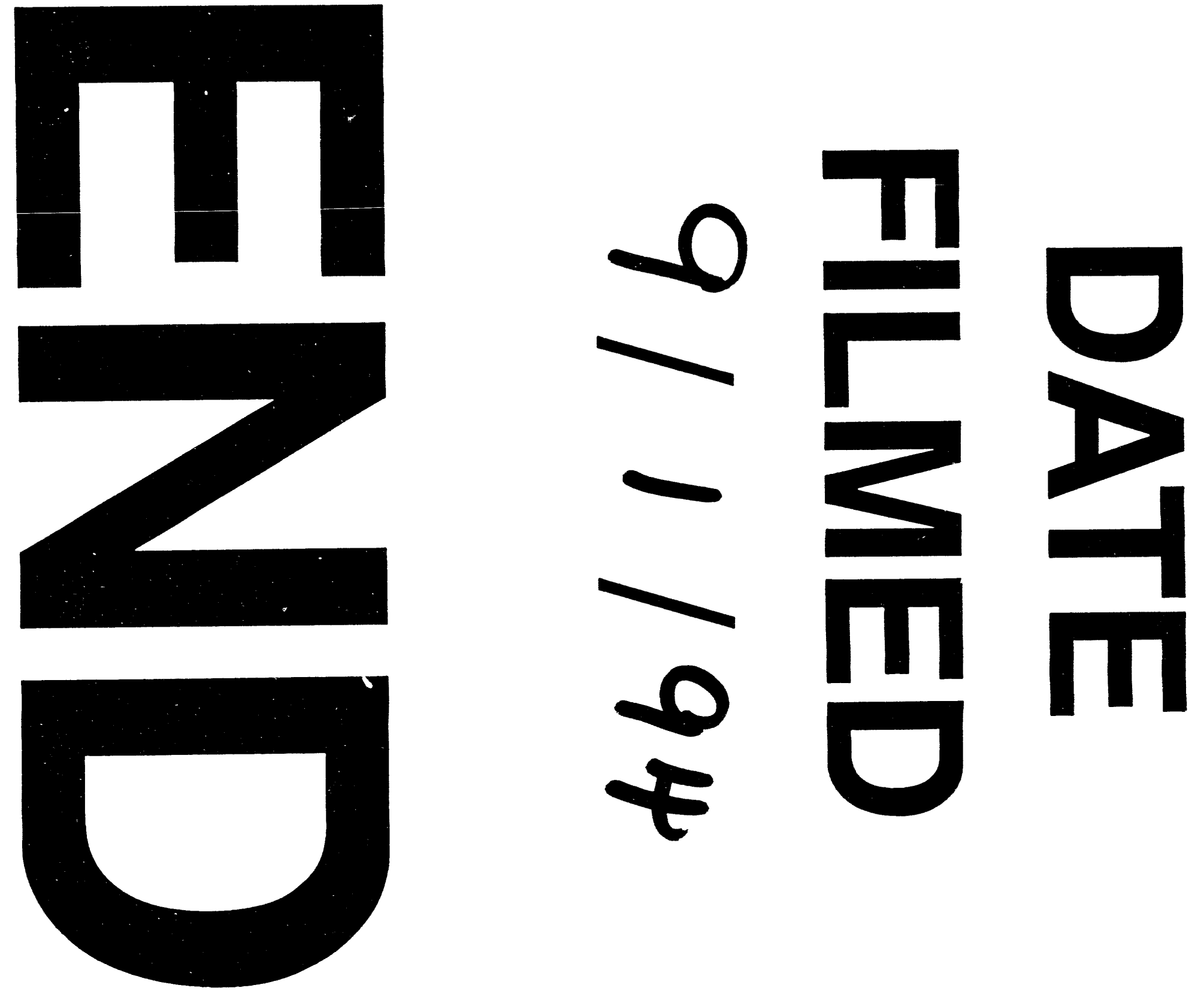
$$
2
$$ 